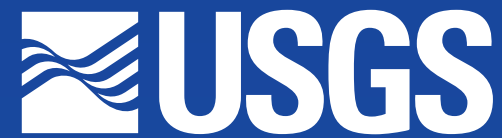

science for a changing world

Occurrence of lsoxaflutole, Acetamide, and Triazine Herbicides and Their Degradation Products in 10 lowa Rivers Draining to the Mississippi and Missouri Rivers, 2004
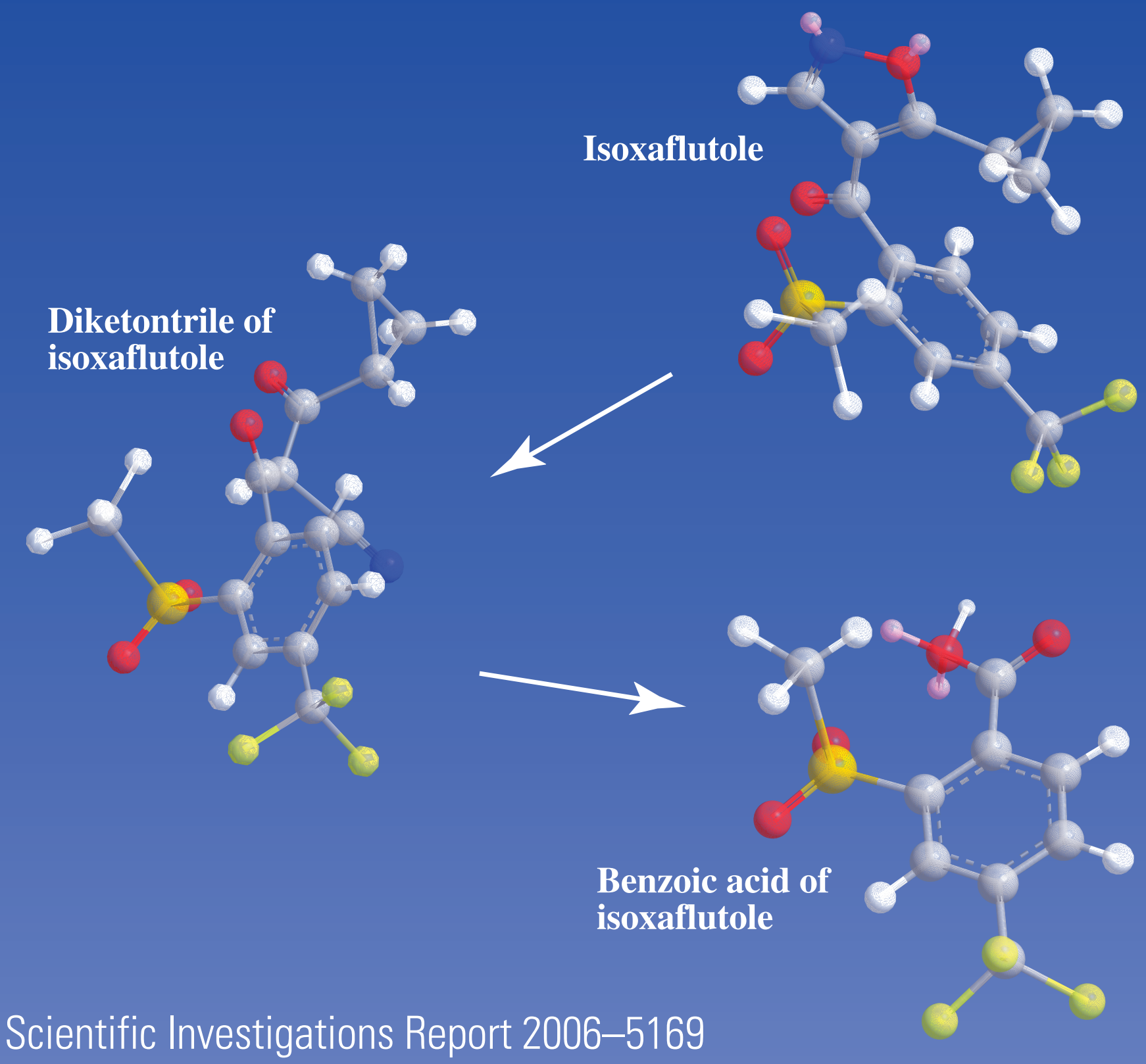

U.S. Department of the Interior

U.S. Geological Survey 



\section{Occurrence of Isoxaflutole, Acetamide, and Triazine Herbicides and Their Degradation Products in 10 lowa Rivers Draining to the Mississippi and Missouri Rivers, 2004}

By Elisabeth A. Scribner, Michael T. Meyer, and Stephen J. Kalkhoff

Scientific Investigations Report 2006-5169 


\section{U.S. Department of the Interior DIRK KEMPTHORNE, Secretary \\ U.S. Geological Survey \\ P. Patrick Leahy, Acting Director}

\section{U.S. Geological Survey, Reston, Virginia: 2006}

For product and ordering information:

World Wide Web: http://www.usgs.gov/pubprod

Telephone: 1-888-ASK-USGS

For more information on the USGS--the Federal source for science about the Earth, its natural and living resources, natural hazards, and the environment:

World Wide Web: http://www.usgs.gov

Telephone: 1-888-ASK-USGS

Any use of trade, product, or firm names is for descriptive purposes only and does not imply endorsement by the U.S. Government.

Although this report is in the public domain, permission must be secured from the individual copyright owners to reproduce any copyrighted materials contained within this report.

Suggested citation:

Scribner, E.A., Meyer, M.T., and Kalkhoff, S.J., 2006, Occurrence of isoxaflutole, acetamide, and triazine herbicides and their degradation products in 10 lowa rivers draining to the Mississippi and Missouri Rivers, 2004: U.S.

Geological Survey Scientific Investigations Report 2006-5169, 84 p. 


\section{Contents}

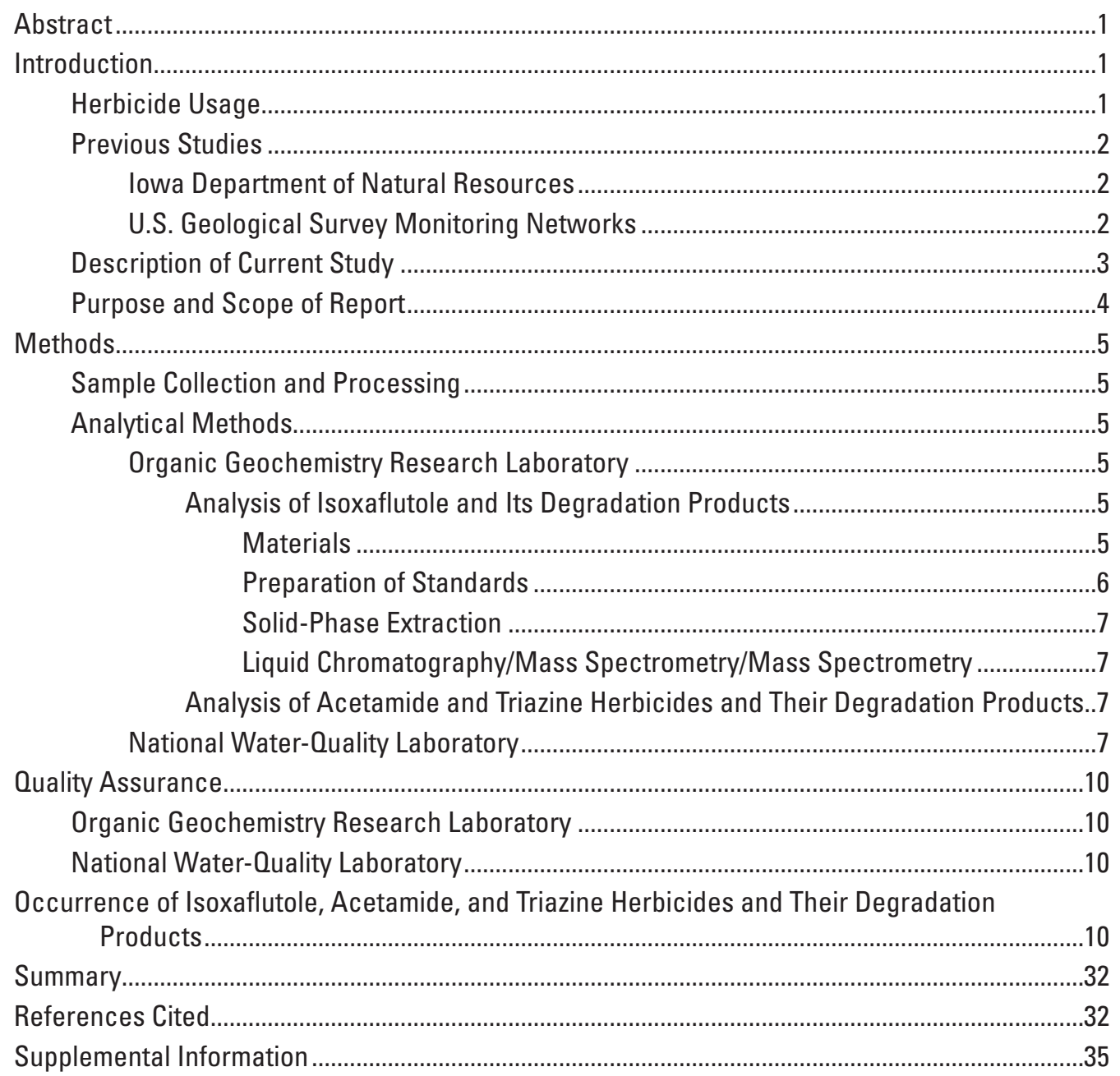

\section{Figures}

1. Graph showing herbicide use in lowa, 1990-2003 .......................................................... 2

2. Map showing location of lowa Department of Natural Resources ambient streammonitoring sites in relation to U.S. Geological Survey streamflow-gaging stations..........3

3. Map showing location of Eastern lowa Basin stream-monitoring trend sites and National Stream Accounting Network sites in lowa in relation to U.S. Geological Survey streamflow-gaging stations.

4. Map showing location of sampling sites on 10 lowa rivers draining to the Mississippi and Missouri Rivers......................................................................................................

5. Chemical structures of isoxaflutole and isoxaflutole degradation products, diketonitrile and benzoic acid

6. Graph showing concentrations of isoxaflutole, diketonitrile, and benzoic acid in water samples collected from 10 rivers in lowa, 2004

7. Graphs showing concentrations of acetochlor, metolachlor, and their degradation products in water samples collected from 10 rivers in lowa, 2004

8. Graph showing concentrations of triazine herbicides and their degradation products in water samples collected from 10 rivers in lowa, 2004. 


\section{Tables}

1. Sampling sites and drainage areas on 10 lowa rivers draining to the Mississippi and Missouri Rivers, 2004

2. Herbicide compounds, laboratory method analysis codes, parameter codes, method numbers, and reporting limits analyzed by the U.S. Geological Survey Organic Geochemistry Research Laboratory for water samples collected from 10 lowa rivers, 2004

3. Pesticide compounds and laboratory reporting limits analyzed by the National WaterQuality Laboratory using laboratory schedule 2001 for water samples collected from 10 lowa rivers, 2004

4. Concentrations of herbicides and their degradation products in quality-assurance samples collected from 10 lowa rivers as determined by the U.S. Geological Survey Organic Geochemistry Research Laboratory, 2004.

5. Percentage recoveries of compounds as determined by U.S. Geological Survey National Water-Quality Laboratory, using laboratory schedule 2001 for water samples collected from 10 lowa rivers, 2004

6. Summary of number and percentage of detections for herbicides and their degradation products analyzed by the U.S. Geological Survey Organic Research Laboratory for water samples collected from 10 rivers in lowa, 2004.

7. Concentrations of isoxaflutole and two degradation products analyzed by the U.S. Geological Survey Organic Geochemistry Research Laboratory for water samples collected from 10 rivers in lowa, 2004.

8. Concentrations of acetamide herbicides and their degradation products analyzed by the U.S. Geological Survey Organic Geochemistry Research Laboratory for water samples collected from 10 rivers in lowa, 2004.

9. Concentrations of triazine and phenylurea herbicides and their degradation products analyzed by the U.S. Geological Survey Organic Geochemistry Research Laboratory for water samples collected from 10 rivers in lowa, 2004

10. Concentrations of selected pesticides and pesticide degradation products determined by the U.S. Geological Survey National Water-Quality Laboratory using laboratory schedule 2001 for water samples collected from 10 rivers in lowa, 2004 


\section{Conversion Factors, Abbreviated Water-Quality Units, and Datum}

\begin{tabular}{lcl}
\hline \multicolumn{1}{c}{ Multiply } & \multicolumn{1}{c}{ By } & \multicolumn{1}{c}{ To obtain } \\
\hline acre & 4,047 & square meter $\left(\mathrm{m}^{2}\right)$ \\
liter $(\mathrm{L})$ & 0.2642 & gallon $(\mathrm{gal})$ \\
microliter $(\mu \mathrm{L})$ & $2.642 \times 10^{-7}$ & gallon $(\mathrm{gal})$ \\
micrometer $(\mu \mathrm{m})$ & $3.937 \times 10^{-5}$ & inch (in.) \\
mile $(\mathrm{mi})$ & 1.609 & kilometer $(\mathrm{km})$ \\
millimeter $(\mathrm{mm})$ & 0.03937 & inch $($ in. $)$ \\
nanogram $(\mathrm{ng})$ & $3.527 \times 10^{-11}$ & ounce $(\mathrm{oz})$ \\
ounce, fluid $(\mathrm{oz})$ & 0.02957 & liter $(\mathrm{L})$ \\
pound $(\mathrm{lb})$ & 453.6 & gram $(\mathrm{g})$ \\
square mile $\left(\mathrm{mi}^{2}\right)$ & 2.590 & square kilometer $\left(\mathrm{km}^{2}\right)$ \\
\hline
\end{tabular}

Temperature can be converted to degrees Celsius $\left({ }^{\circ} \mathrm{C}\right)$ or degrees Fahrenheit $\left({ }^{\circ} \mathrm{F}\right)$ by the equations:

$$
\begin{aligned}
& { }^{\circ} \mathrm{C}=5 / 9\left({ }^{\circ} \mathrm{F}-32\right) \\
& { }^{\circ} \mathrm{F}=9 / 5\left({ }^{\circ} \mathrm{C}\right)+32 .
\end{aligned}
$$

\section{Abbreviated Water-Quality Units}

microgram per liter ( $\mu \mathrm{g} / \mathrm{L})$

microgram per milliliter $(\mu \mathrm{g} / \mathrm{mL})$

milligram per milliliter $(\mathrm{mg} / \mathrm{mL})$

milliliter $(\mathrm{mL})$

nanogram per microliter (ng/ $\mathrm{LL}$ )

\section{Datum}

Horizontal coordinate information is referenced to the North American Datum of 1983 (NAD 83). 


\title{
Occurrence of Isoxaflutole, Acetamide, and Triazine Herbicides and Their Degradation Products in 10 lowa Rivers Draining to the Mississippi and Missouri Rivers, 2004
}

\author{
By Elisabeth A. Scribner, Michael T. Meyer, and Stephen J. Kalkhoff
}

\begin{abstract}
During 2004, a study to document the occurrence of herbicides and herbicide degradation products was conducted for 10 major Iowa rivers draining to the Missouri and Mississippi Rivers. Seventy-five water-quality samples were collected to measure isoxaflutole, acetamide, and triazine herbicides and their herbicide degradation products. An analytical method to measure isoxaflutole and its degradation products, diketonitrile and benzoic acid, was developed by the U.S. Geological Survey Organic Geochemistry Research Laboratory in Lawrence, Kansas, using vacuum manifold solid-phase extraction and liquid chromatography/mass spectrometry/mass spectrometry and is described in this report.

Isoxaflutole, a low application rate preemergence herbicide for control of annual broadleaf weeds, is used extensively in Iowa. Findings from the study documented in this report indicate that isoxaflutole was designed to degrade quickly to diketonitrile, which appears to be more stable, and then to benzoic acid. Of the 75 samples collected to measure isoxaflutole, there were four detections of isoxaflutole, 56 detections of diketonitrile, and 43 detections of benzoic acid. Also, results of acetamide and triazine water-quality samples correlate with past studies, which indicate that herbicide degradation products are detected more frequently and often at higher concentrations in surface water than their parent compounds.

In addition to analysis of isoxaflutole and its degradation products, samples were analyzed by the USGS National Water-Quality Laboratory schedule 2001 for about 52 pesticides and their degradation products.
\end{abstract}

\section{Introduction}

Iowa is one of the most productive agricultural areas in the United States for corn. Crops grown in the State are used to produce food, fuel, and fiber. Agricultural chemicals are needed for crops to control competing vegetation, insects, and fungus, and to supply sufficient nutrients. The use of pesticides and fertilizer has resulted in substantial crop yields, but certain climate conditions often result in agricultural chemicals being applied before rainfall that produces runoff and washing of the chemicals into streams and rivers. The presence of pesticides used in agricultural and urban areas has been documented in rivers and streams in Iowa and throughout the Midwestern United States. These contaminants can have an effect on water quality in local streams, downstream on major rivers such as the Mississippi and Missouri Rivers, and the Gulf of Mexico.

\section{Herbicide Usage}

Modern agricultural practices in the United States often involve widespread use of herbicides for production of crops. Herbicide use is one factor that affects the concentrations of herbicides measured in Midwestern streams (Battaglin and Goolsby, 1999; Coupe and Goolsby, 1999; Scribner and others, 2000a) and an important reason for monitoring the water quality in streams.

Isoxaflutole was patented by the Rhone-Poulenc Agriculture Company (Basel, Switzerland) in 1990. The Rhone-Poulenc Agriculture Company merged with AgrEvo (a company of Hoescht and Schering) in 1999 to form Aventis CropScience (Lyon, France), which was purchased by Bayer CropScience (Research Triangle Park, North Carolina) in 2001 (Luscombe and others, 1995).

Isoxaflutole, a member of the benzoyl isoxazole family, is a low-application-rate preemergence herbicide for control of annual broadleaf weeds and some grasses in field corn and sugar cane (Pallet and others, 2001). For example, in Iowa isoxaflutole was applied at $0.07 \mathrm{lb}$ active ingredient per acre per year during 2003 compared to atrazine, applied at $0.91 \mathrm{lb}$ active ingredient per acre per year, and metolachlor, applied at $1.9 \mathrm{lb}$ active ingredient per acre per year (U.S. Department of Agriculture, 2004). The intended strategy of the manufacturer is that under field conditions, isoxaflutole, also known by 


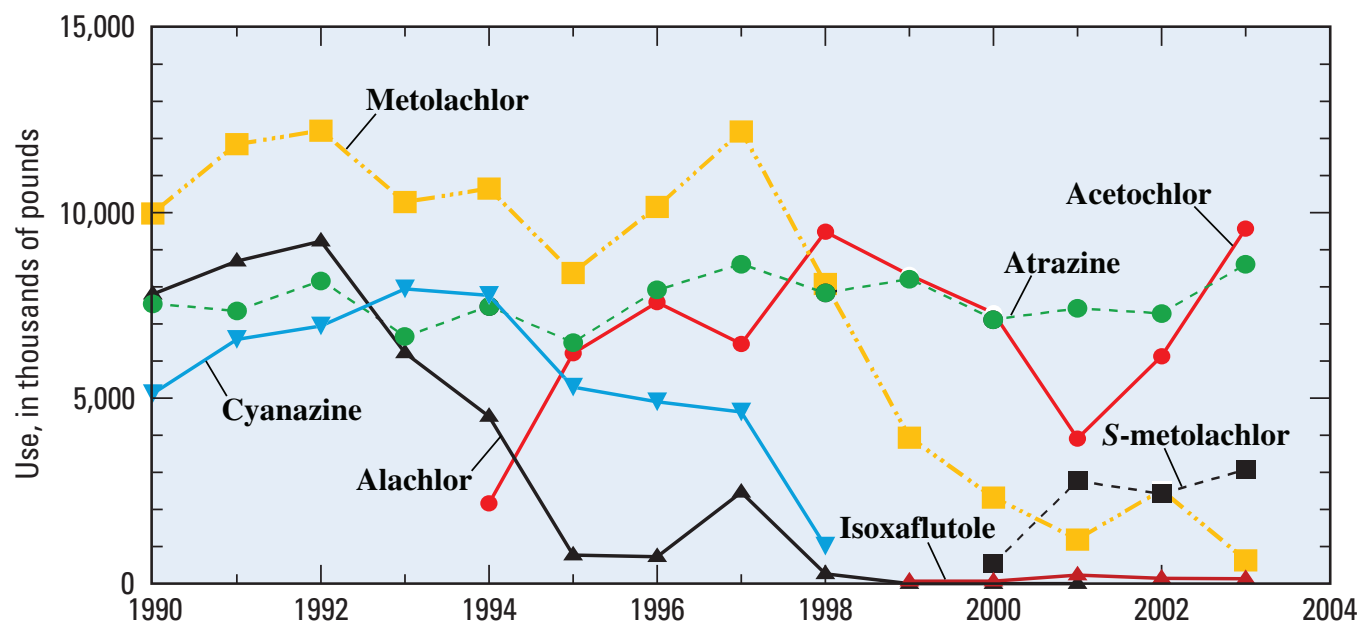

Figure 1. Herbicide use in lowa, 1990-2003 (data from U.S. Department of Agriculture, 2004). its trade name Balance, degrades quickly to the biologically active diketonitrile (Lin and others, 2002), followed by conversion of diketonitrile to benzoic acid. Diketonitrile also is more water soluble than isoxaflutole, and therefore, its transport to surface or ground water is a concern.

Isoxaflutole was first used in 1999 in the United States, and usage has fluctuated from 213,000 $\mathrm{lb}$ in 1999, peaking at 439,000 lb in 2001, then decreasing to 321,000 lb in 2003 (U.S. Department of Agriculture, 2004). Isoxaflutole usage in Iowa (fig. 1) was 62,000 lb in 1999 and 2000, peaking at $229,000 \mathrm{lb}$ in 2001, then decreasing to 135,000 lb in 2003.

The historical use of acetochlor, alachlor, atrazine, cyanazine, metolachlor, and $S$-metolachlor in Iowa is also shown in figure 1. Acetochlor was introduced in 1994 with its registration contingent on it reducing the use of other corn herbicides. As a preemergent herbicide, acetochlor rapidly replaced alachlor. As can be seen in figure 1, acetochlor usage in Iowa was about 2 million $\mathrm{lb}$ in 1994 increasing to 9.5 million $\mathrm{lb}$ in 2003 compared to alachlor usage which was at its peak of more than 9 million $\mathrm{lb}$ in 1992 declining to about 250,000 lb in 1998 (U.S. Department of Agriculture, 2004). Atrazine usage in Iowa stayed steady between 7 and 8.5 million $\mathrm{lb}$ during 1990 to 2003 regardless of the two decreases in the maximum application rate of atrazine recommended on the manufacturers' labels during the 1990s (Scribner and others, 2005). The manufacture of cyanazine was discontinued in 1999, with distribution of existing supplies discontinued on September 30, 2002 (Scribner and others, 1998). Cyanazine usage in Iowa declined to about 1 million lb in 1998 (fig. 1). The formulation of metolachlor has been refined to include primarily the active $S$-isomer ( $S$-metolachlor), which reduced required application rates substantially (Benbrook, 2001). Iowa usage of metolachlor and $S$-metolachlor can be seen as metolachlor peaked at a rate of 12 million $\mathrm{lb}$ in 1997, then declined to about $600,000 \mathrm{lb}$ by 2003 while $S$-metolachlor rapidly increased from usage of 2.7 million $\mathrm{lb}$ in 2001 to more than 3 million $\mathrm{lb}$ in 2001 (fig. 1).

\section{Previous Studies}

The effects of agricultural and urban land use on the quality of Iowa's rivers and streams have been assessed during the last 30 years by several State and Federal agencies. Monitoring networks have been established by the Iowa Department of Natural Resources (IADNR) and the U.S. Geological Survey (USGS) as described in the following sections.

\section{lowa Department of Natural Resources}

The IADNR Ambient Water Monitoring Program conducts an ongoing assessment of the condition of Iowa's ground- and surface-water resources and reports the results to the public (Iowa Department of Natural Resources, 2001). Beginning in 1995, water samples were collected by IADNR personnel at a network of 84 sites on Iowa's rivers located upstream and downstream from Iowa's larger urban areas. Figure 2 shows IADNR ambient stream-monitoring sites in relation to USGS streamflow-gaging stations.

\section{U.S. Geological Survey Monitoring Networks}

The USGS National Stream Accounting Network (NASQAN) was begun in 1973 to provide nationally comparable information on the status of and trends in water quality (Hooper and others, 1997). Water-quality measurements were made quarterly at sites at the downstream end of most hydrologic accounting units to be consistent with the design of the national streamflow-gaging network. In 1995, the NASQAN program was redesigned to focus on monitoring water quality in four of the Nation's largest rivers, of which the Mississippi River Basin is the largest. The chemical constituents measured include 52 water-soluble pesticides. Samples are collected from 6 to 15 times per year at various NASQAN sites. Iowa NASQAN sites are shown in relation to USGS gaging stations in figure 3. 


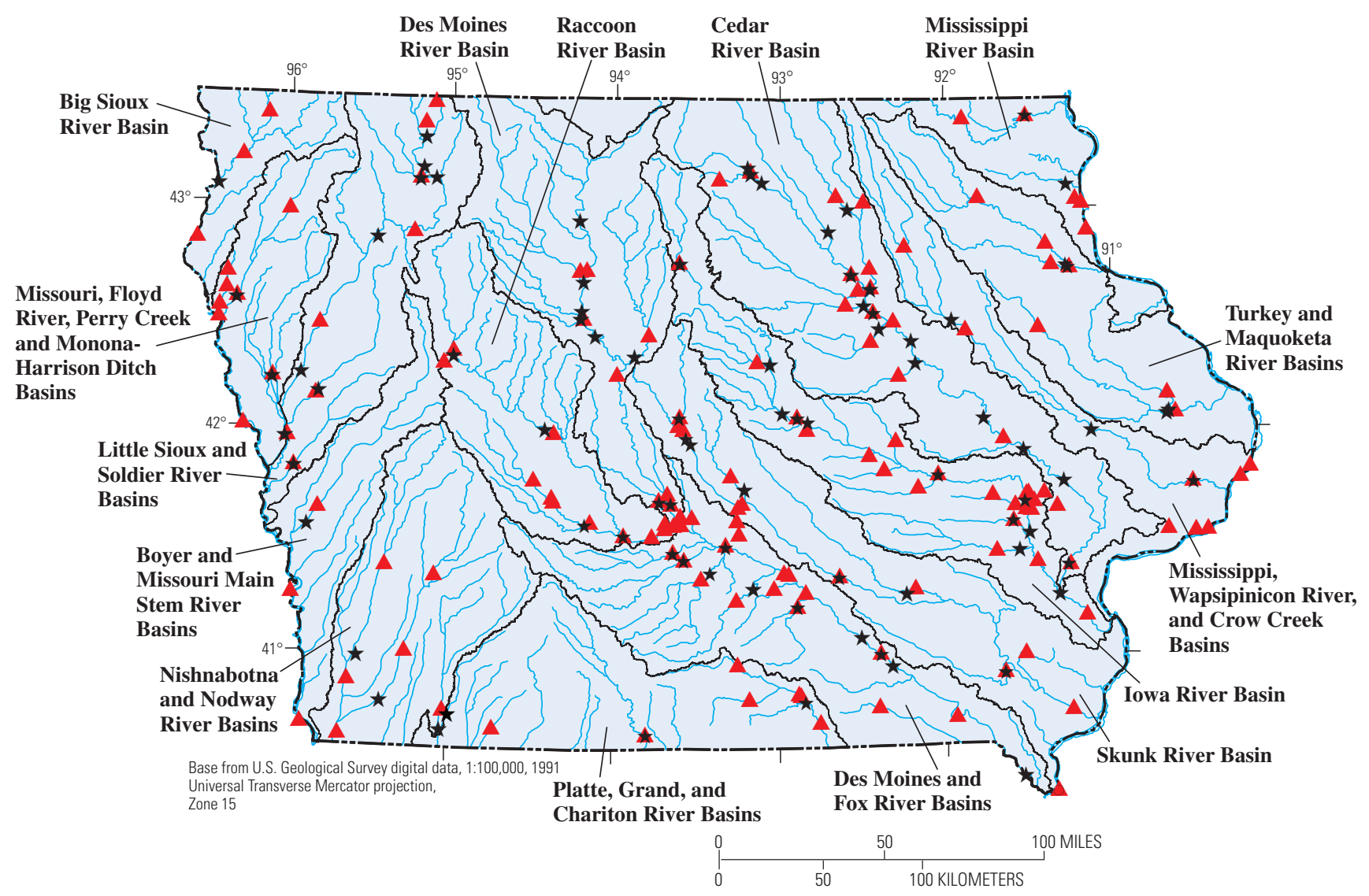

\section{EXPLANATION}

- River basin boundary
$\star \quad \begin{aligned} & \text { Iowa Department of Natural Resources ambient } \\ & \text { stream-monitoring site }\end{aligned}$
॥ U.S. Geological Survey streamflow-gaging station

Figure 2. Location of lowa Department of Natural Resources (IADNR) ambient stream-monitoring sites in relation to U.S. Geological Survey streamflow-gaging stations (modified from lowa Department of Natural Resources, 2001).

In 1991, the USGS began the National Water-Quality Assessment (NAWQA) Program. The long-term goals of this program are to describe the status and trends in the quality of a large, representative part of the Nation's surface- and groundwater resources and to identify the major factors that affect the quality of the resources. The NAWQA Program has identified more than 50 study units throughout the United States for which water quality was assessed (Gilliom and Hamilton, 2006; Gilliom and others, 2006). The Eastern Iowa Basins (EIWA) study unit was selected as an important hydrologic system representative of an agricultural area in the Midwest. The EIWA study unit encompasses the Wapsipinicon, the Cedar, the Iowa, and the Skunk River Basins in eastern Iowa and southern Minnesota as shown in figure 3.

Surface-water data collection activities in the EIWA study unit began in March 1996, and during the high-intensity phase of data collection (1996-98), water-quality samples were collected monthly from 12 sites on rivers and streams in the study unit. Two of these 12 sites were former NASQAN locations
(Iowa River at Wapello-station 05465500; Skunk River at Augusta-station 05474000). As part of the trends network of NAWQA, 4 of the 12 EIWA sites continue to be sampled (fig. 3). Data are published annually in the Iowa annual water data report (Nalley and others, 2001). Continuous streamdischarge data are an integral part of the program, and thus streamflow gages are located at all NAWQA sites (fig. 3).

\section{Description of Current Study}

More than 26,000 mi of rivers and perennial streams drain the approximately $56,000 \mathrm{mi}^{2}$ of Iowa (Iowa Department of Natural Resources, 2001). Many of the major rivers drain directly to the Mississippi River, but a number of rivers in western Iowa drain to the Missouri River. To meet the objectives of this study, 10 sites were selected near the mouth of major rivers draining Iowa for sampling. Samples were collected monthly from March to September at each site, and high-flow samples were collected at 7 of the 10 sites 


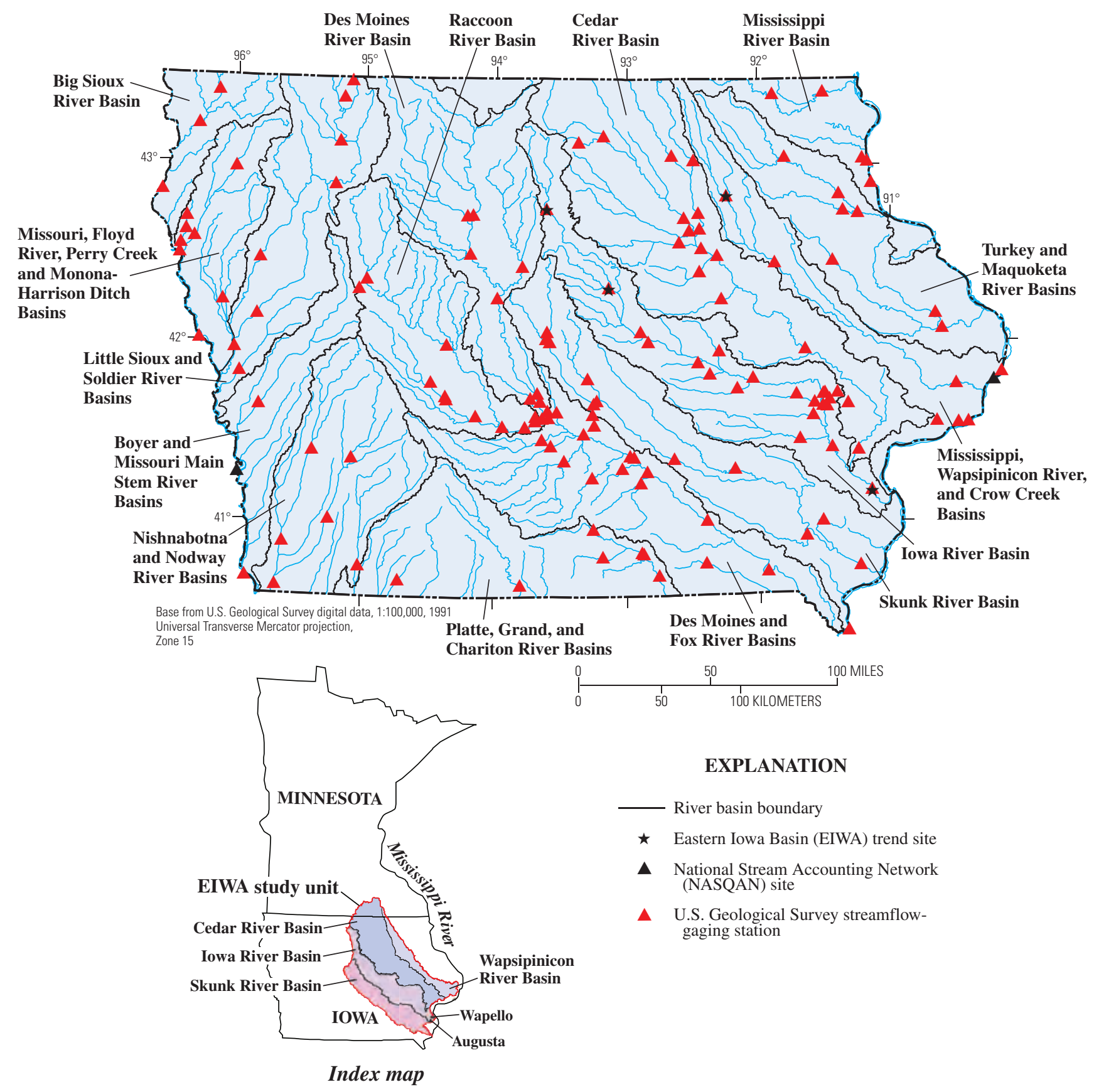

Figure 3. Location of Eastern lowa Basin (EIWA) stream-monitoring trend sites and National Stream Accounting Network (NASQAN) sites in lowa in relation to U.S. Geological Survey streamflow-gaging stations.

(stations 05412500, 05418600, 05422000, 06485500, 06607500, 06609500, and 06810000; table 1) and analyzed for relevant constituents. The location of sampling sites is shown in figure 4, and sampling-site drainage areas are given in table 1 .

\section{Purpose and Scope of Report}

The main purpose of this report is to document the occurrence of the herbicide isoxaflutole and two of its degradation products (diketonitrile and benzoic acid) in 10 major rivers in Iowa that drain the Missouri and Mississippi Rivers (table 1) during the spring and summer of 2004. As part of quantifying isoxaflutole and its degradation products in rivers, the report describes an analytical method, using solid-phase extraction (SPE) and liquid chromatography/mass spectrometry/mass spectrometry (LC/MS/MS), developed by the USGS Organic Geochemistry Research Laboratory (OGRL), Lawrence, Kansas. The report also provides the results of analysis of waterquality samples for the occurrence of acetamide and triazine herbicides and their degradation products by two separate 
Table 1. Sampling sites and drainage areas on 10 lowa rivers draining to the Mississippi and Missouri Rivers, 2004.

\begin{tabular}{|c|c|c|c|}
\hline $\begin{array}{l}\text { Map number } \\
\text { (fig. 4) }\end{array}$ & $\begin{array}{c}\text { U.S. Geological Survey } \\
\text { site identification } \\
\text { number }\end{array}$ & Site name & $\begin{array}{l}\text { Drainage area } \\
\text { (square miles) }\end{array}$ \\
\hline \multicolumn{4}{|c|}{ Mississippi River Basin } \\
\hline 1 & 05412500 & Turkey River at Garber & 1,545 \\
\hline 2 & 05418600 & Maquoketa River near Spragueville & 1,635 \\
\hline 3 & 05422000 & Wapsipinicon River near DeWitt & 2,330 \\
\hline 4 & 05474000 & Skunk River at Augusta & 4,303 \\
\hline 5 & 05490500 & Des Moines River at Keosauqua & 14,038 \\
\hline \multicolumn{4}{|c|}{ Missouri River Basin } \\
\hline 6 & 06485500 & Big Sioux River at Akron & 8,424 \\
\hline 7 & 06607500 & Little Sioux River near Turin & 3,526 \\
\hline 8 & 06609500 & Boyer River at Logan & 871 \\
\hline 9 & 06810000 & Nishnabotna River above Hamburg & 2,806 \\
\hline 10 & 06904010 & Chariton River near Moulton & 740 \\
\hline
\end{tabular}

LC/MS methods at the OGRL. The USGS National WaterQuality Laboratory (NWQL), Lakewood, Colorado, analyzed for about 52 pesticides and degradation products.

\section{Methods}

\section{Sample Collection and Processing}

During 2004, samples were collected monthly from March to September using methods described in Shelton (1994) and equal-width increment sampling, which is a collection of composite samples across a section of stream with equidistant verticals and equal transit rates within each vertical that yields a representative sample of stream condition (Webb and others, 1999). The water samples were filtered through a $0.7-\mu \mathrm{m}$ pore-size baked glass-fiber filter, using an aluminum plate filter holder and a ceramic-piston fluid-metering pump with all Teflon tubing, into precleaned $123-\mathrm{mL}$ amber glass bottles. All sampling equipment was cleaned with a Liquinox solution, rinsed thoroughly with tapwater, then rinsed with organic-free or reagent water, followed by a final rinse with methanol and organic-free water to remove traces of methanol. The equipment then was air dried. The filtrate was collected in six heat-cleaned 125-L amber glass bottles. The remainder of the water in the compositing container was used for onsite measurements of specific conductance, $\mathrm{pH}$, and water temperature (Wilde and others, 1998).

All samples were chilled immediately and shipped to the USGS OGRL in Lawrence, Kansas, and NWQL in Lakewood, Colorado, for analyses. Samples were refrigerated at approximately $4{ }^{\circ} \mathrm{C}$ until analysis.

\section{Analytical Methods}

Analysis of herbicides was provided by the USGS OGRL and the USGS NWQL as described in this section.

\section{Organic Geochemistry Research Laboratory}

An analytical method was developed using vacuum manifold SPE and LC/MS/MS to measure isoxaflutole [5cyclopropyl-4-(2-methylsulfonyl-4-(trifluoromethylbenzoyl) isoxazole] and its degradation products, diketonitrile [1-(2methylsulfonyl-4-trifluoromethylphenyl)-2-cyano-3-cyclopropyl propan-1, 3-dione] and benzoic acid [2-methylsulphonyl4(trifluoromethyl) benzoic acid]. Chemical structures of these compounds are shown in figure 5. A detailed description of this method is provided in the following section. Analytical methods using SPE and LC/MS were developed to analyze water samples for acetamide and triazine herbicides (Scribner and others, 2000b). Herbicide compounds, method analysis, and reporting limits are listed in table 2.

\section{Analysis of Isoxaflutole and Its Degradation Product}

An analytical method for isoxaflutole and its degradation products was developed at the OGRL. The method includes SPE with LC/MS/MS and uses electrospray ionization (ESI) in negative-ion mode. The analytical method used to analyze isoxaflutole and its degradation products is currently (2006) undergoing USGS evaluation.

\section{Materials}

Isoxaflutole, diketonitrile, and benzoic acid were obtained from the U.S. Environmental Protection Agency (USEPA) repository (Fort Meade, Maryland). The internal 


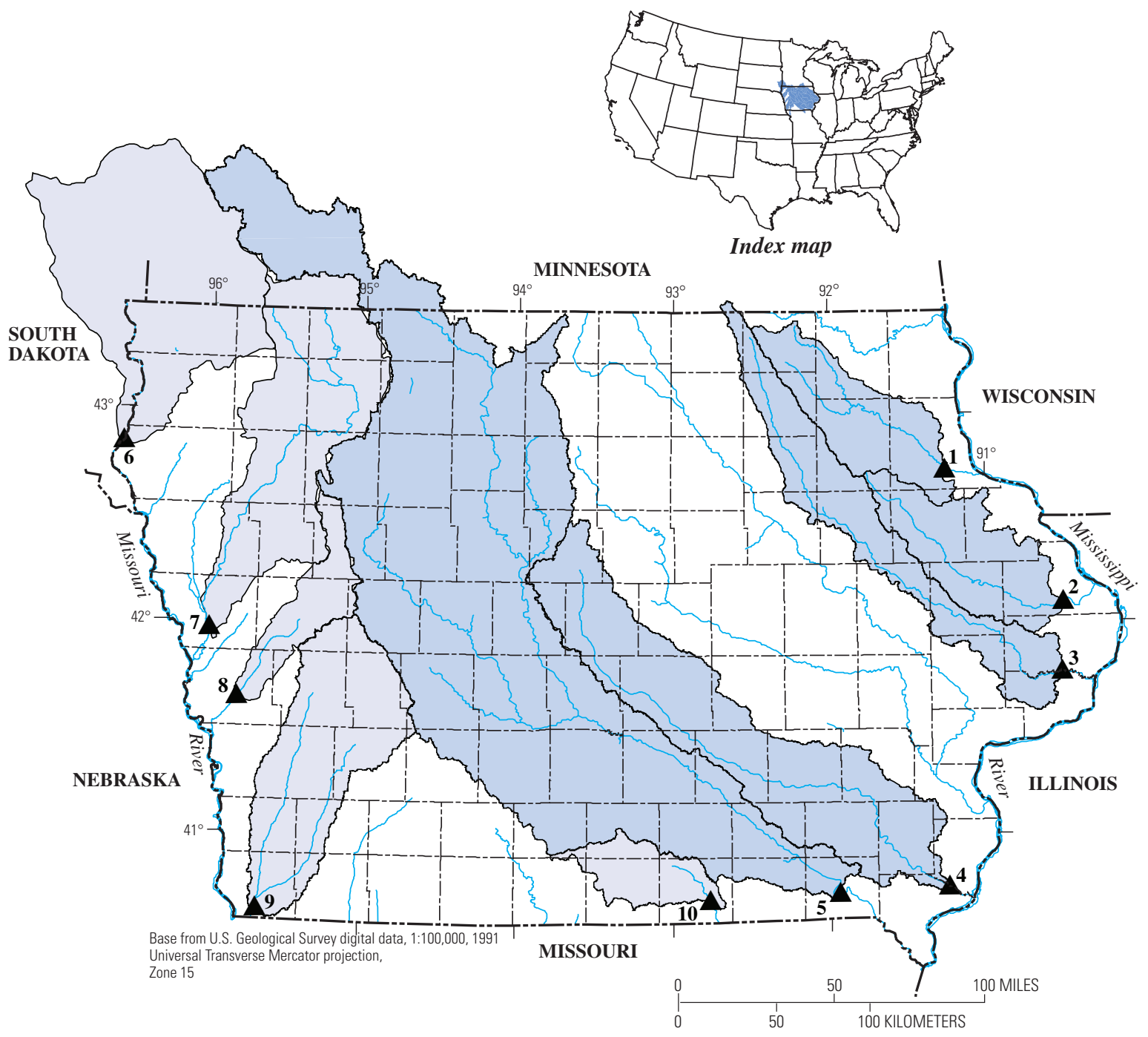

EXPLANATION

Missouri River drainage basin

Mississippi River drainage basin

Sampling site and map number

Figure 4. Location of sampling sites on 10 lowa rivers draining to the Mississippi and Missouri Rivers.

standard (ISTD), 2-4, dichlorophenoxyacetic acid- $\mathrm{d}_{3}$, was obtained from Cambridge Isotope Laboratory (Andover, Massachusetts). The surrogate standard, alachlor ethanesulfonic acid (ESA)- $\mathrm{D}_{5}$, was provided by Monsanto (St. Louis, Missouri). All solvents were HPLC (high-performance liquid chromatography) grade, and the acetic acid was ACS (American Chemical Society) certified.

\section{Preparation of Standards}

Individual solutions of the ISTD, 2-4, dichlorophenoxyacetic acid- $\mathrm{d}_{3}$, and the surrogate standard, alachlor ESA-d $\mathrm{d}_{5}$, were prepared, using volumetric procedures, at a concentration of $0.615 \mathrm{ng} / \mu \mathrm{L}$ methanol from $1-\mathrm{mg} / \mathrm{mL}$ stock solution. An intermediate standard mix containing isoxaflutole, diketonitrile, and benzoic acid was prepared by diluting individual $1-\mathrm{mg} / \mathrm{mL}$ stock solutions into acetonitrile to a concentration of $12.3 \mathrm{ng} / \mu \mathrm{L}$. Using volumetric procedures, a working standard mix of $0.123 \mathrm{ng} / \mu \mathrm{L}$ was prepared from the intermediate standard mix by diluting it 1:100 into 9:1 formic acid (1.1 percent aqueous) in reagent water and acetonitrile.

Calibration curve solutions were prepared for extraction in new 4-oz amber bottles by adding $75 \mathrm{~mL}$ reagent water, $0.5 \mathrm{~mL}$ of $1-\mathrm{mg} / \mathrm{mL}$ aqueous humic acid solution, and $0.25 \mathrm{~mL}$ water pollution (WP) minerals A and B. The working standard mix then was added to each calibration standard to obtain final concentrations of $0,0.005,0.010,0.050,0.100$, 


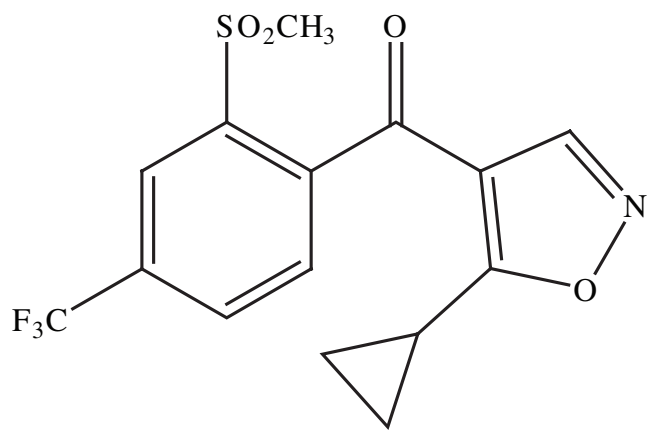

soxaflutole [5-cyclopropyl-4-(2-methylsulfonyl-4(trifluoromethylbenzoyl) isoxazole]

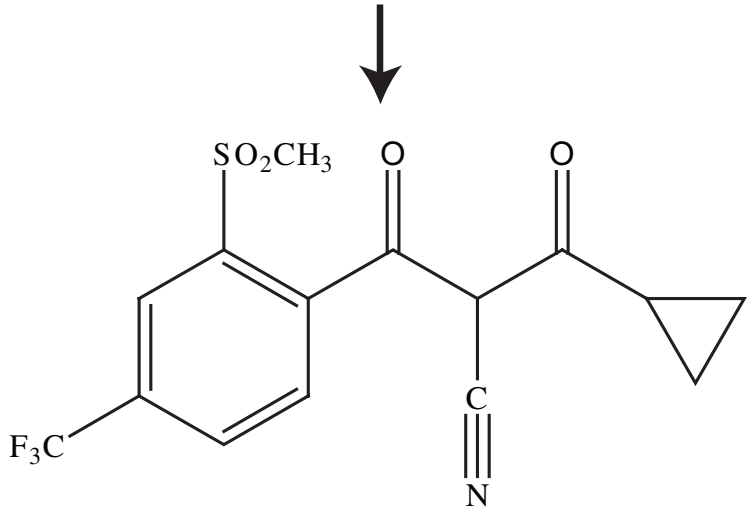

Diketonitrile of isoxaflutole [1-(2-methylsulfonyl-4trifluoromethylphenyl)-2-cyano-3-cyclopropyl propan-1, 3-dione]

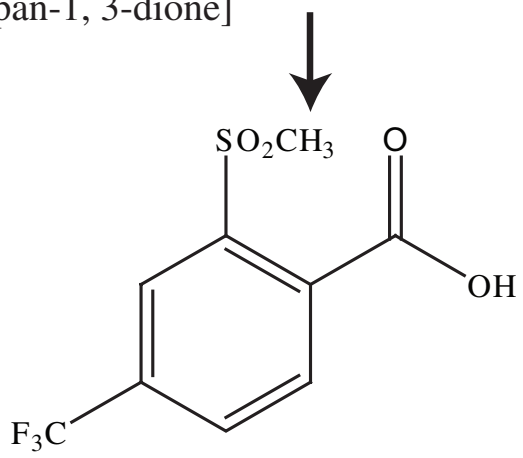

Benzoic acid of isoxaflutole [2-methylsulfonyl-4(trifluoromethyl) benzoic acid]

Figure 5. Chemical structures of isoxaflutole and isoxaflutole degradation products, diketonitrile, and benzoic acid.

and $0.200 \mu \mathrm{g} / \mathrm{L}$. Finally, reagent water was added to bring the final volume of the calibration solutions to $123 \mathrm{~mL}$. The bottles then were capped and mixed well.

\section{Solid-Phase Extraction}

Blank samples, standards, and environmental samples were prepared by adding $100 \mu \mathrm{L}$ of $0.615-\mathrm{ng} / \mu \mathrm{L}$ surrogate and $100 \mu \mathrm{L}$ of glacial acetic acid to all bottles. One hundred microliters $(100 \mu \mathrm{L})$ of $0.615-\mathrm{ng} / \mu \mathrm{L}$ working standard solution was added to each matrix spike bottle. SPE cartridges were prepared by passing $5 \mathrm{~mL}$ of 50/50 methanol and acetonitrile and $5 \mathrm{~mL}$ of reagent water slowly through each cartridge. Samples were loaded onto the cartridges within 15 to 20 minutes under vacuum. Cartridges were washed by adding $3 \mathrm{~mL}$ of aqueous 1-percent formic acid under vacuum. Compounds then were eluted from the cartridge with two 4-mL aliquots of $50 / 50$ methanol/acetonitrile to each cartridge. Then $100 \mu \mathrm{L}$ of 0.615 -ng/ $\mu \mathrm{L}$ ISTD solution were added to each sample tube. Sample eluates were reduced to a volume of $200 \mu \mathrm{L}$ using a Zymark turbovap at $45^{\circ} \mathrm{C}$. Sample extracts were transferred to $200-\mu \mathrm{L}$ autosampler vials and stored in a freezer at $-10{ }^{\circ} \mathrm{C}$ until analysis.

\section{Liquid Chromatography/Mass Spectrometry/Mass Spectrometry}

Samples were analyzed on an Agilent 1100 series liquid chromatography (LC) system (Wilmington, Delaware) and a Waters Quattro Micro API triple-stage quadrupole mass spectrometer (MS/MS) system in electrospray negative ionization mode (Milford, Massachusetts). A Keystone 250- x 4.6-mm C-18 analytical column was used to separate isoxaflutole and its degradation products (Bellefonte, Pennsylvania). The LC column was equilibrated with the mobile phase for approximately 2 hours prior to analysis. Method reporting limits are given in table 2.

\section{Analysis of Acetamide and Triazine Herbicides and Their Degradation Products}

Method number 0-2139-03 was used to analyze 6 acetamide parent herbicides and 26 acetamide degradation products. This method is identified by the USGS OGRL with the method analysis code of LCPD (Lee and Strahan, 2003). The method reporting limit for LCPD is $0.02 \mu \mathrm{g} / \mathrm{L}$ (table 2).

Method number 0-2138-02 was used to analyze 6 triazine parent herbicides, 12 triazine degradation products, 3 phenylurea parent compounds, and 1 phenylurea degradation product. This method is identified by the USGS laboratory with the method analysis code of LCEA (Lee and others, 2002). The method reporting limits for LCEA were $0.025 \mu \mathrm{g} / \mathrm{L}$ for all triazine herbicides except deethylcyanazine, for which the reporting limit was $0.20 \mu \mathrm{g} / \mathrm{L}$. The method reporting limit for phenylurea herbicides was $0.20 \mu \mathrm{g} / \mathrm{L}$ (table 2).

\section{National Water-Quality Laboratory}

The NWQL analyzed 106 samples for 52 pesticides and degradation products using laboratory schedule 2001. Analytes for this laboratory schedule are listed in table 3. Details of the analytical methods for NWQL schedule 2001 can be found in Zaugg and others (1995), Lindley and others (1996), and Madsen and others (2003). Various laboratory reporting limits are reported in table 3 . 
Table 2. Herbicide compounds, laboratory method analysis codes, parameter codes, method numbers, and reporting limits analyzed by the U.S. Geological Survey Organic Geochemistry Research Laboratory, Lawrence, Kansas, for water samples collected from 10 lowa rivers, 2004.

[USGS, U.S. Geological Survey; $\mu \mathrm{g} / \mathrm{L}$, micrograms per liter; ESA, ethanesulfonic acid; OXA, oxanilic acid; SAA, sulfynil acetic acid; --, USGS method under review]

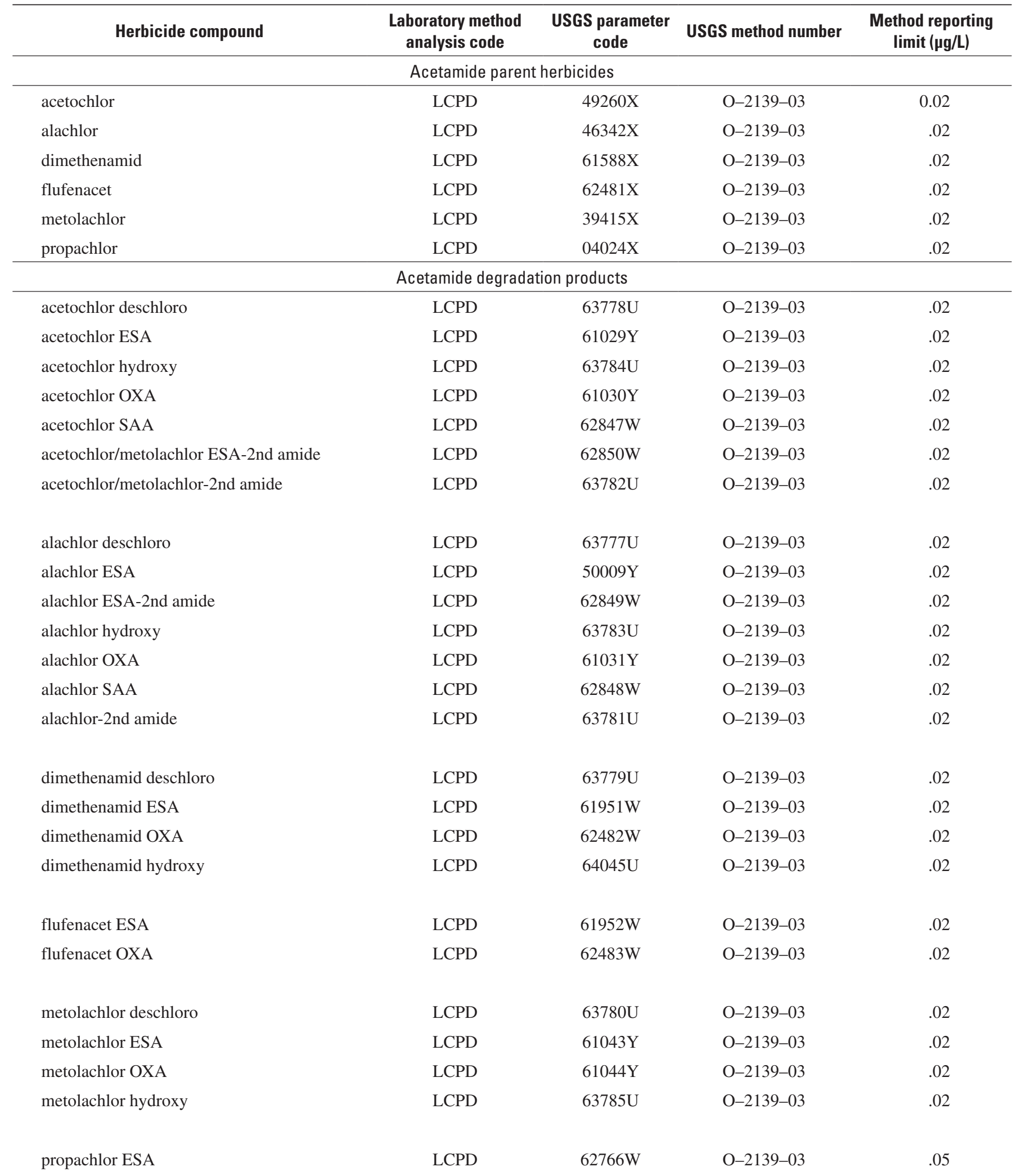


Table 2. Herbicide compounds, laboratory method analysis codes, parameter codes, method numbers, and reporting limits analyzed by the U.S. Geological Survey Organic Geochemistry Research Laboratory, Lawrence, Kansas, for water samples collected from 10 lowa rivers, 2004. - Continued

[USGS, U.S. Geological Survey; $\mu \mathrm{g} / \mathrm{L}$, micrograms per liter; ESA, ethanesulfonic acid; OXA, oxanilic acid; SAA, sulfynil acetic acid; --, USGS method under review]

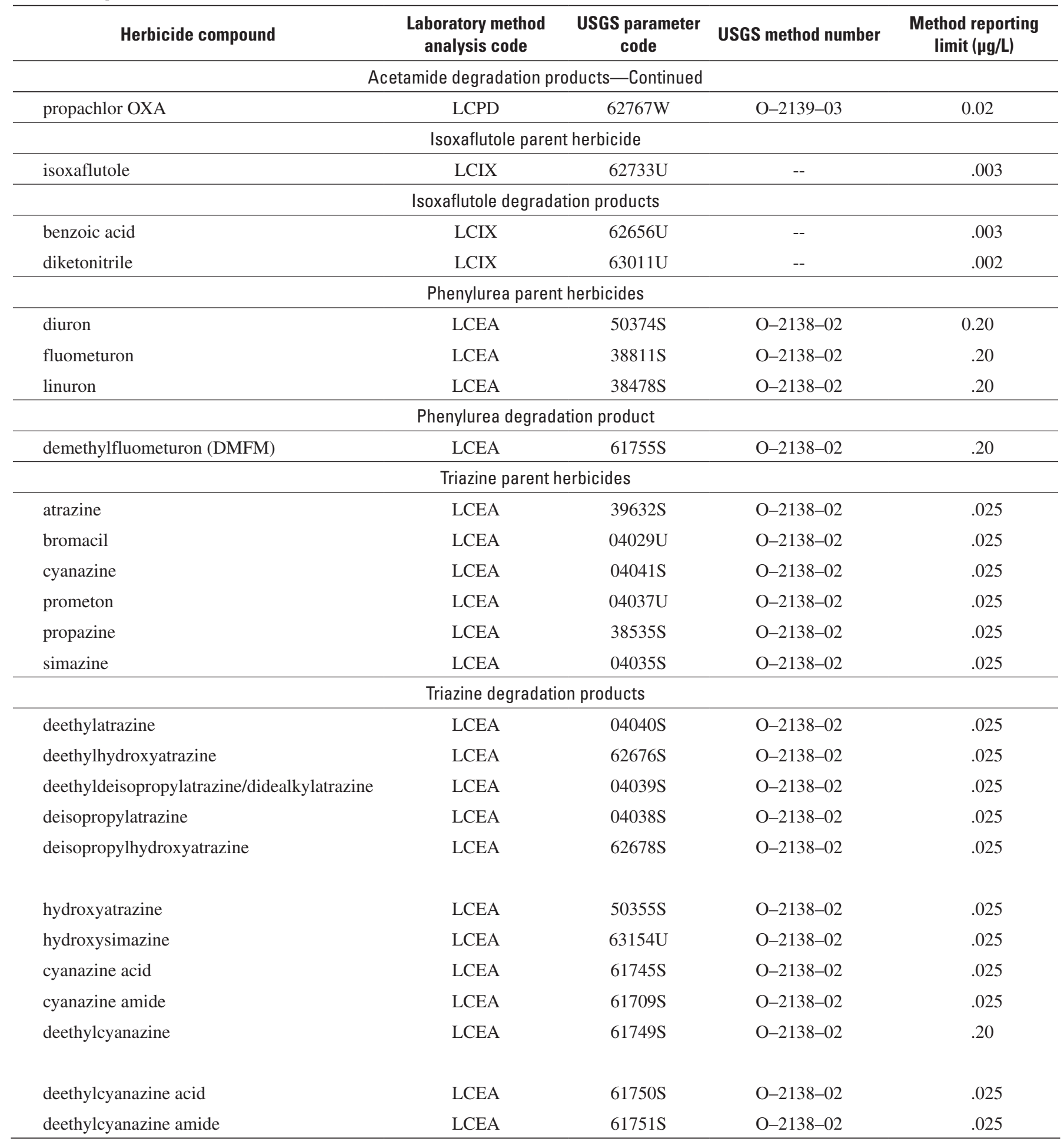




\section{Quality Assurance}

All water-quality measurements and water samples for this study were collected by USGS personnel in accordance with a written work plan for the study (on file with the USGS in Iowa City, Iowa). Field blank and equipment blank samples were collected to ensure cross contamination did not occur due to contaminated equipment. Replicate samples were collected to document analytical variability.

\section{Organic Geochemistry Research Laboratory}

Results of herbicide concentrations in qualityassurance samples collected during 2004 are shown in table 4 . All samples were collected in duplicate or more. Analytical control was maintained by the use of carryover blanks, laboratory duplicates, laboratory spiked samples, and calibration verification standards. Types of quality assurance/quality control (QA/QC) samples collected during the study for acetamide parent and degradation products included 2 field blank, 1 field replicate, 10 laboratory duplicate, and 8 laboratory spiked samples. QA/QC samples collected for triazine parent compounds and degradation products included one field blank, seven laboratory duplicate, and five laboratory spiked samples. QA/QC samples collected for isoxaflutole and degradation products included seven laboratory duplicate and eight laboratory spiked samples. Herbicides were not detected in any of the field or laboratory blanks.

\section{National Water-Quality Laboratory}

Surrogate herbicides were added to all environmental and blank samples analyzed for pesticides by the USGS NWQL. Surrogates in samples analyzed by laboratory schedule 2001 (table 3 ) were diazinon- $\mathrm{d}_{10}$ and alpha $\mathrm{HCH}-\mathrm{d}_{6}$. Surrogate herbicides were similar in chemical properties to some target analytes but were not expected to be present in the environmental samples. Surrogate herbicides are used to assess extraction efficiency and to detect sample-handling problems in the laboratory. The percentage recoveries of surrogate compounds analyzed is shown in table 5. Diazinon- $\mathrm{d}_{10}$ had a maximum of 131 and minimum of 65 percent recovery of the 106 water samples analyzed, whereas alpha $\mathrm{HCH}-\mathrm{d}_{6}$ had a maximum of 114 and a minimum of 58 percent recovery, which indicates an overall acceptable method performance.

\section{Occurrence of Isoxaflutole, Acetamide, and Triazine Herbicides and Their Degradation Products}

A summation of the number and percentage of detections of herbicides and their degradation products analyzed by the USGS OGRL are presented in table 6. Of the 75 samples analyzed, isoxaflutole was only present in four samples, and these were collected during the postplanting (May-June) season. During this season, there were 27 samples analyzed for isoxaflutole at a 15-percent detection rate. This concurs with prior findings that isoxaflutole has a very short half-life of less than 24 hours and rapidly converts to diketonitrile (Pallett and others, 2001; Lin and others, 2002). After application, isoxaflutole becomes herbicidally active through opening of the isoxazole ring, becoming the diketonitrile degradation product. Then, diketonitrile is transformed further to a herbicidally inactive benzoic acid degradation product (Viviani and others, 1998). Diketonitrile (56 detections) and benzoic acid (43 detections) were present in samples collected from all three sampling periods. However, as shown in table 6, the maximum number and percentage of detections for both compounds occurred during the postplanting season with diketonitrile detected in all 27 samples (100 percent) and benzoic acid in 23 of the 27 samples ( 85 percent).

The concentration results for isoxaflutole, diketonitrile, and benzoic acid are shown in figure 6 and table 7 . Results show that the maximum concentration of isoxaflutole was $0.077 \mu \mathrm{g} / \mathrm{L}$, whereas diketonitrile had a maximum concentration of $0.552 \mu \mathrm{g} / \mathrm{L}$, and the highest concentration for benzoic acid was $0.166 \mu \mathrm{g} / \mathrm{L}$. Maximum concentrations for all three compounds appeared during the postplanting season.

Because isoxaflutole is applied at a low application rate and has a very short half-life, a stable analytical method proved necessary to reach acceptable method detection and reporting limits. The method developed to analyze isoxaflutole and its degradation products by LC/MS/MS was an important breakthrough and contributed to an improved understanding of the occurrence, persistence, and transport of isoxaflutole and its degradation products in the environment.

Detections for five acetamide herbicides and their degradation products are summarized by number and percentage in table 6, which shows that metolachlor was the most frequently detected acetamide parent (59 of 60 samples) during all three sampling periods, followed by acetochlor (41/60). Ethanesulfonic acid (ESA) and oxanilic acid (OXA) degradation products of acetochlor (60/60 ESA and 60/60 OXA), alachlor (56/60 and 53/60), and metolachlor (60/60 and 60/60) were detected as frequently or more frequently than their parent compounds during all three sampling periods.

Acetochlor, acetochlor ESA and OXA, metolachlor, and metolachlor ESA and OXA were detected at a 100-percent detection (29/29) frequency in water-quality samples collected during the postplanting season. Acetochlor was detected at a 100 -percent detection frequency in water-quality samples collected during the postplanting season (table 6).

As shown in figure $7 A$ and in table 8 at the back of this report, acetochlor had the highest concentration $(8.6 \mu \mathrm{g} / \mathrm{L})$ of all the analyzed acetamide compounds in samples collected during the postplanting season. The maximum concentrations of acetochlor ESA and OXA collected during the postplanting 
Table 3. Pesticide compounds and laboratory reporting limits analyzed by the National Water-Quality Laboratory, Lakewood, Colorado, using laboratory schedule 2001 for water samples collected from 10 lowa rivers, 2004.

\begin{tabular}{|c|c|c|c|}
\hline Pesticide compound & $\begin{array}{l}\text { Laboratory reporting } \\
\text { limit } \\
\text { (micrograms per liter) }\end{array}$ & Pesticide compound & $\begin{array}{l}\text { Laboratory reporting } \\
\text { limit } \\
\text { (micrograms per liter) }\end{array}$ \\
\hline 2,6-diethylaniline & 0.006 & fipronil sulfone & .024 \\
\hline acetochlor & .006 & fonofos & .003 \\
\hline alachlor & .005 & lindane & .004 \\
\hline alpha-HCH & .005 & linuron & .035 \\
\hline atrazine & .007 & malathion & .027 \\
\hline azinphos-methyl & .050 & metolachlor & 0.006 \\
\hline benfluralin & .010 & metribuzin & .006 \\
\hline butylate & .004 & molinate & .003 \\
\hline carbaryl & .041 & napropamide & .007 \\
\hline carbofuran & .020 & $\mathrm{p}, \mathrm{p}$ '-DDE & .003 \\
\hline chlorpyrifos & .005 & parathion & .010 \\
\hline cis-permethrin & .006 & parathion-methyl & .015 \\
\hline cyanazine & .018 & pebulate & .004 \\
\hline dacthal (DCPA) & .003 & pendimethalin & .022 \\
\hline deethylatrazine (DEA) & .006 & phorate & .011 \\
\hline desulfinylfipronil & .012 & prometon & .010 \\
\hline desulfinylfipronil amide & .029 & propachlor & .025 \\
\hline diazinon & .005 & propanil & .011 \\
\hline dieldrin & .009 & propargite & .023 \\
\hline disulfoton & .021 & propyzamide & .004 \\
\hline EPTC (s-ethyl dipropylthiocarbamate) & .004 & simazine & .005 \\
\hline ethalfluralin & .009 & tebuthiuron & .016 \\
\hline ethoprophos & .005 & terbacil & .034 \\
\hline fipronil & .016 & terbufos & .017 \\
\hline \multirow[t]{3}{*}{ fipronil sulfide } & .013 & thiobencarb & .010 \\
\hline & & tri-allate & .006 \\
\hline & & trifluralin & .009 \\
\hline
\end{tabular}

season were considerably less than their parent herbicide at 2.9 and $2.3 \mu \mathrm{g} / \mathrm{L}$, respectively (fig. $7 A$ ).

The highest concentration for metolachlor was $3.8 \mu \mathrm{g} / \mathrm{L}$ from samples collected during the postplanting season; however, metolachlor ESA had a maximum concentration of $2.9 \mu \mathrm{g} / \mathrm{L}$, which was analyzed from a sample collected during the late summer (July-September) (fig. 7B). As can be seen from the analytical results in table 8 , ESA and OXA products of acetochlor, alachlor, dimethenamid, and metolachlor were detected almost as frequently or more frequently than their parent herbicides. There were no detections of alachlor deschloro, alachlor hydroxy, alachlor 2nd amide, dimethenamid hydroxy, propachlor, propachlor ESA, and propachlor OXA.

Measurable amounts of atrazine, the most frequently detected triazine parent herbicide during all three sampling periods (64 detections of 67 samples), occurred in 19 of 


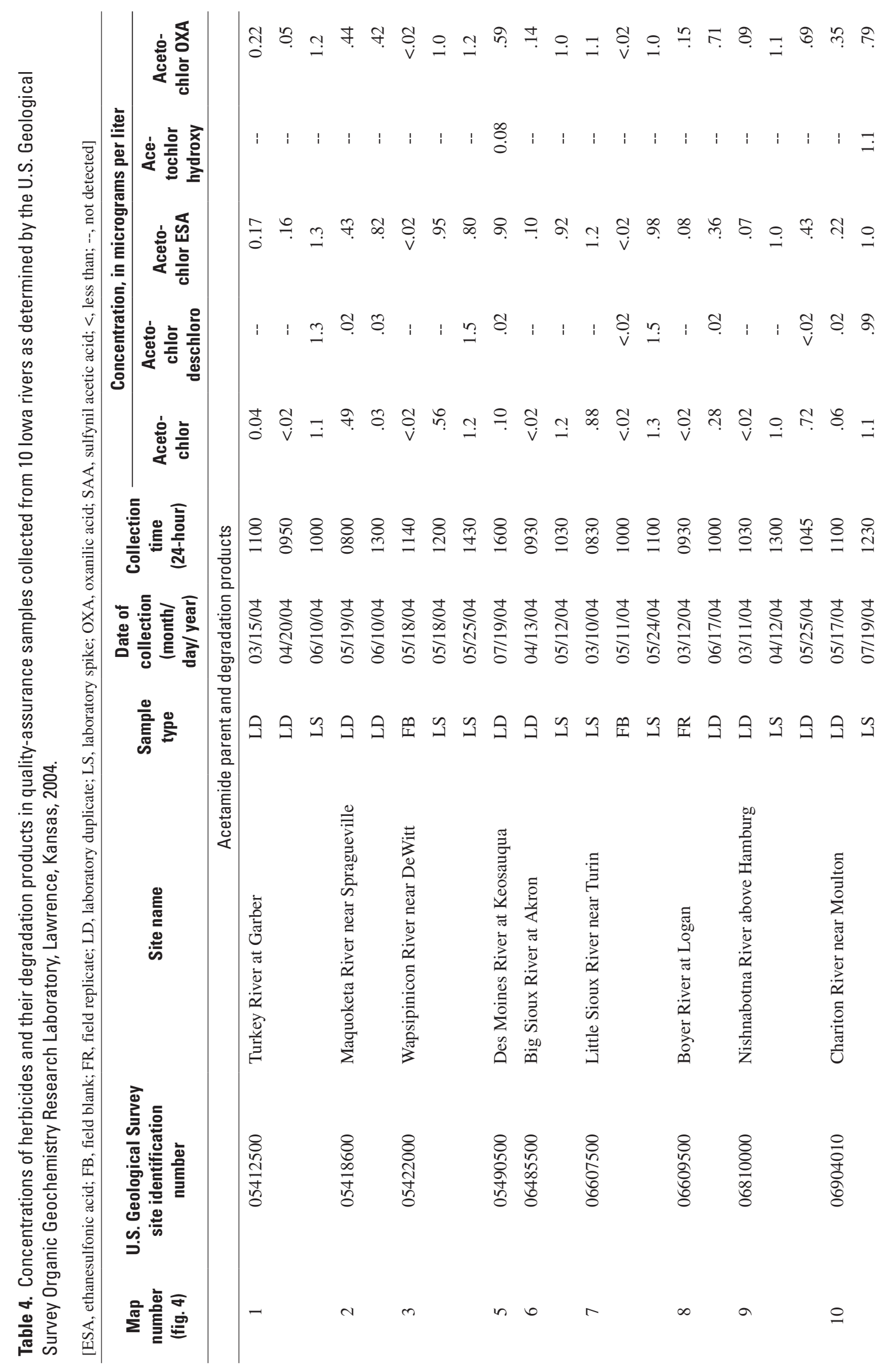




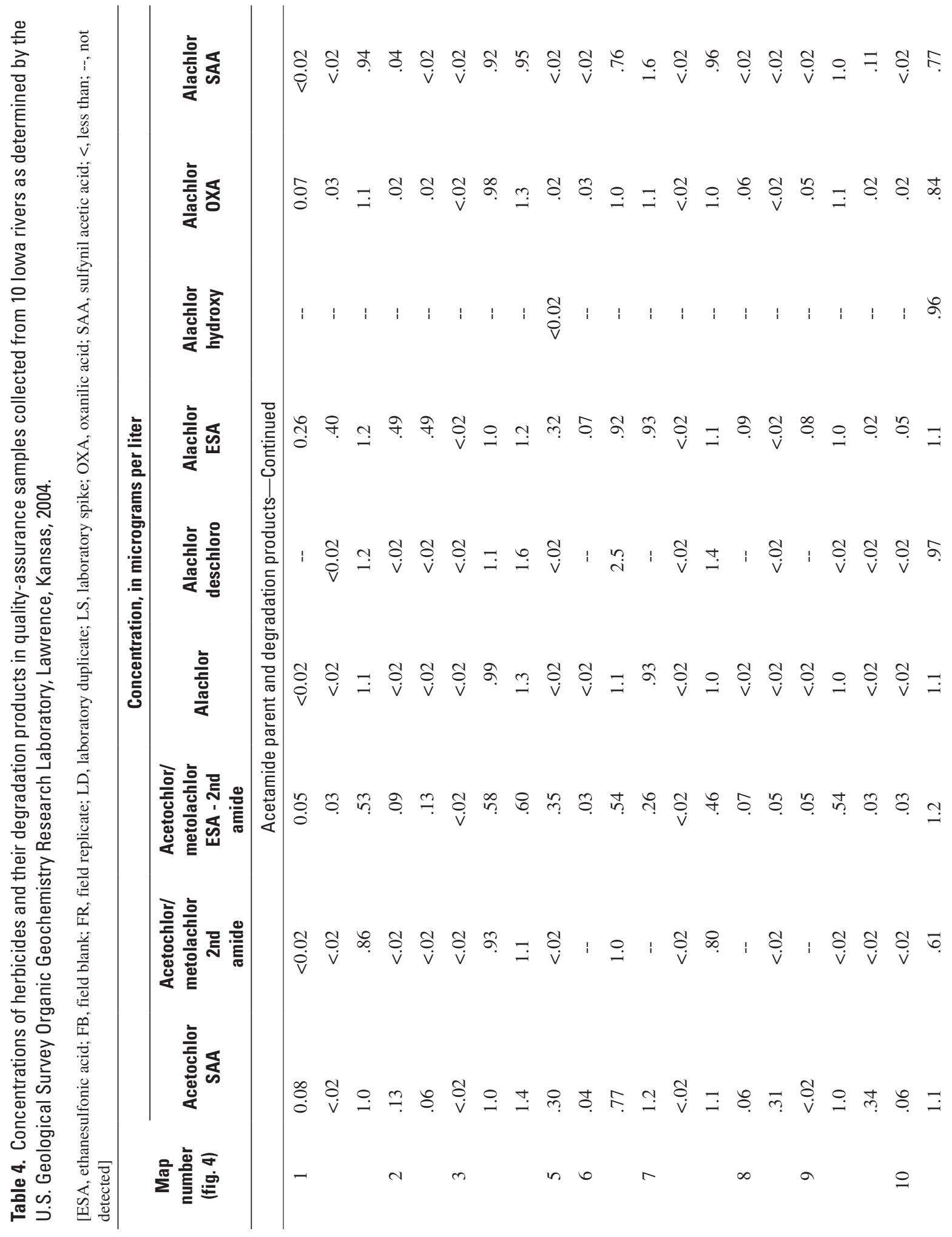




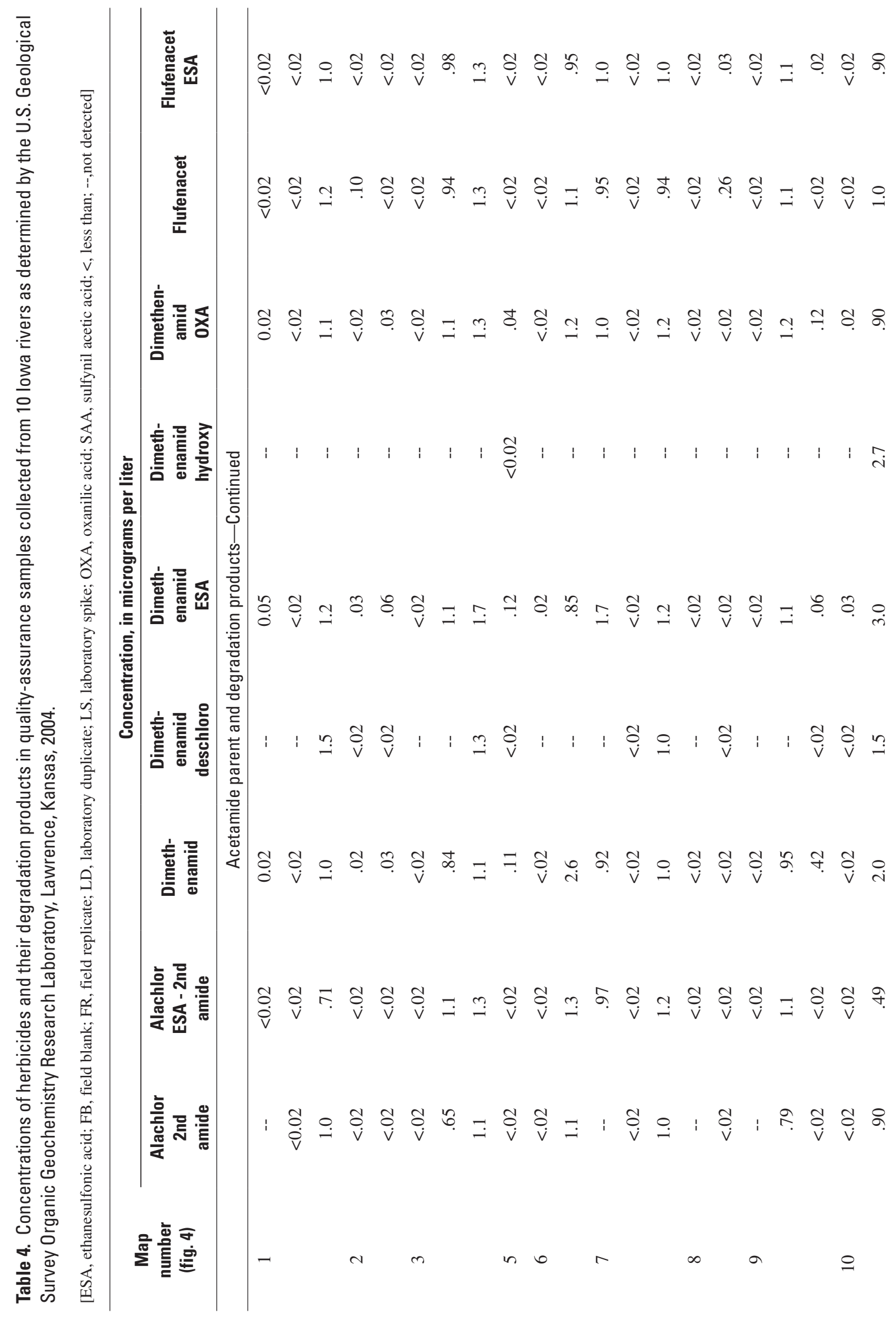




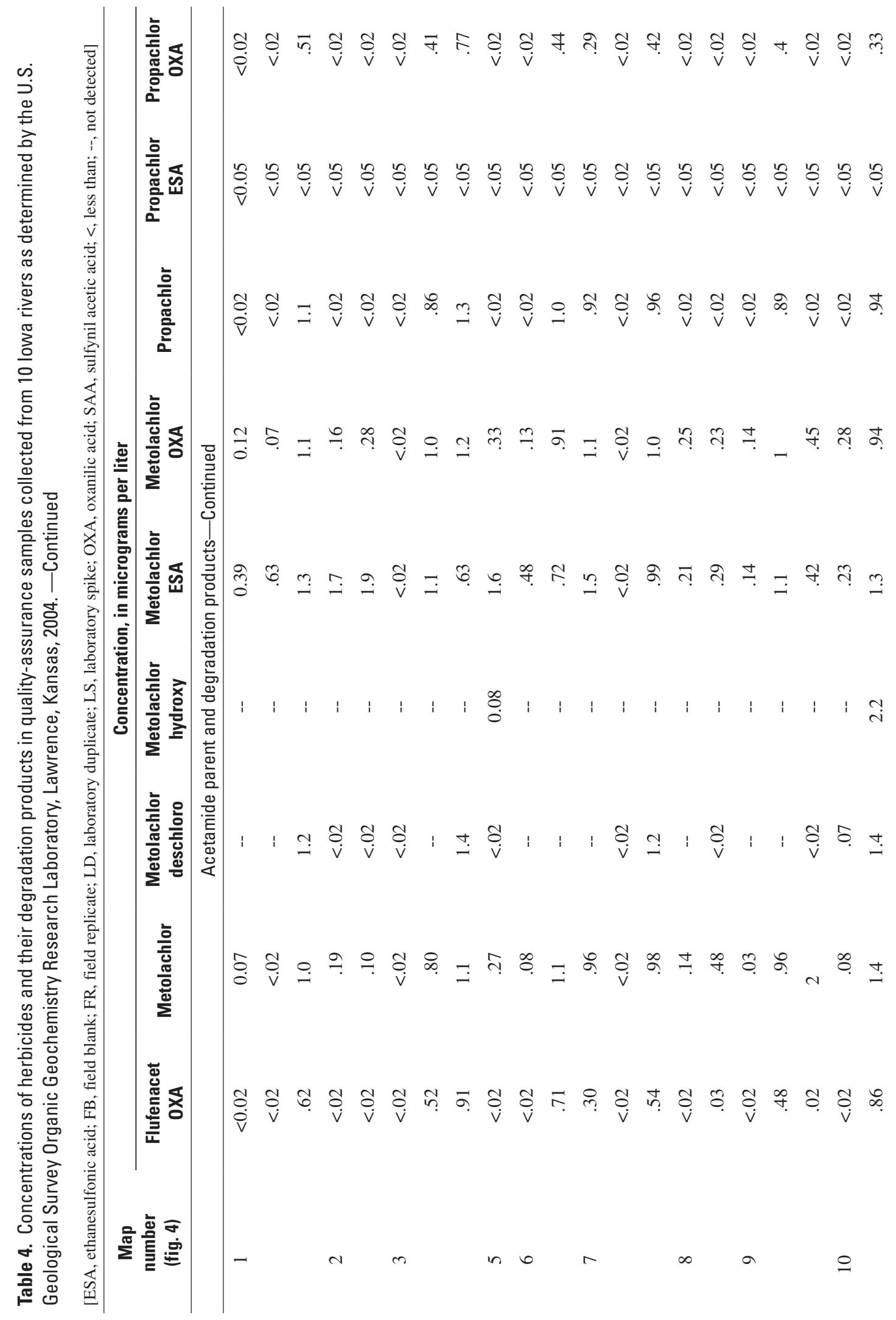




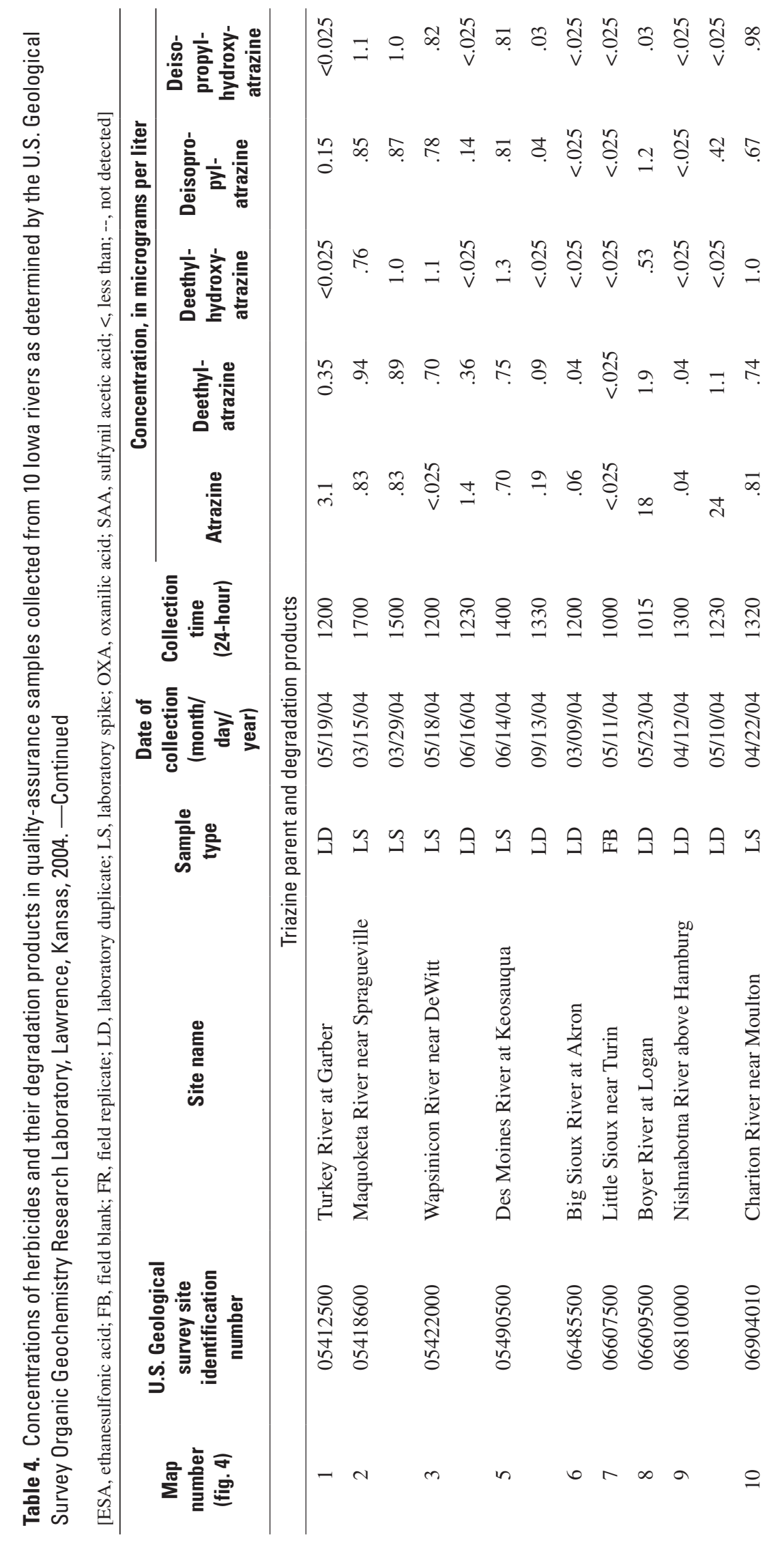




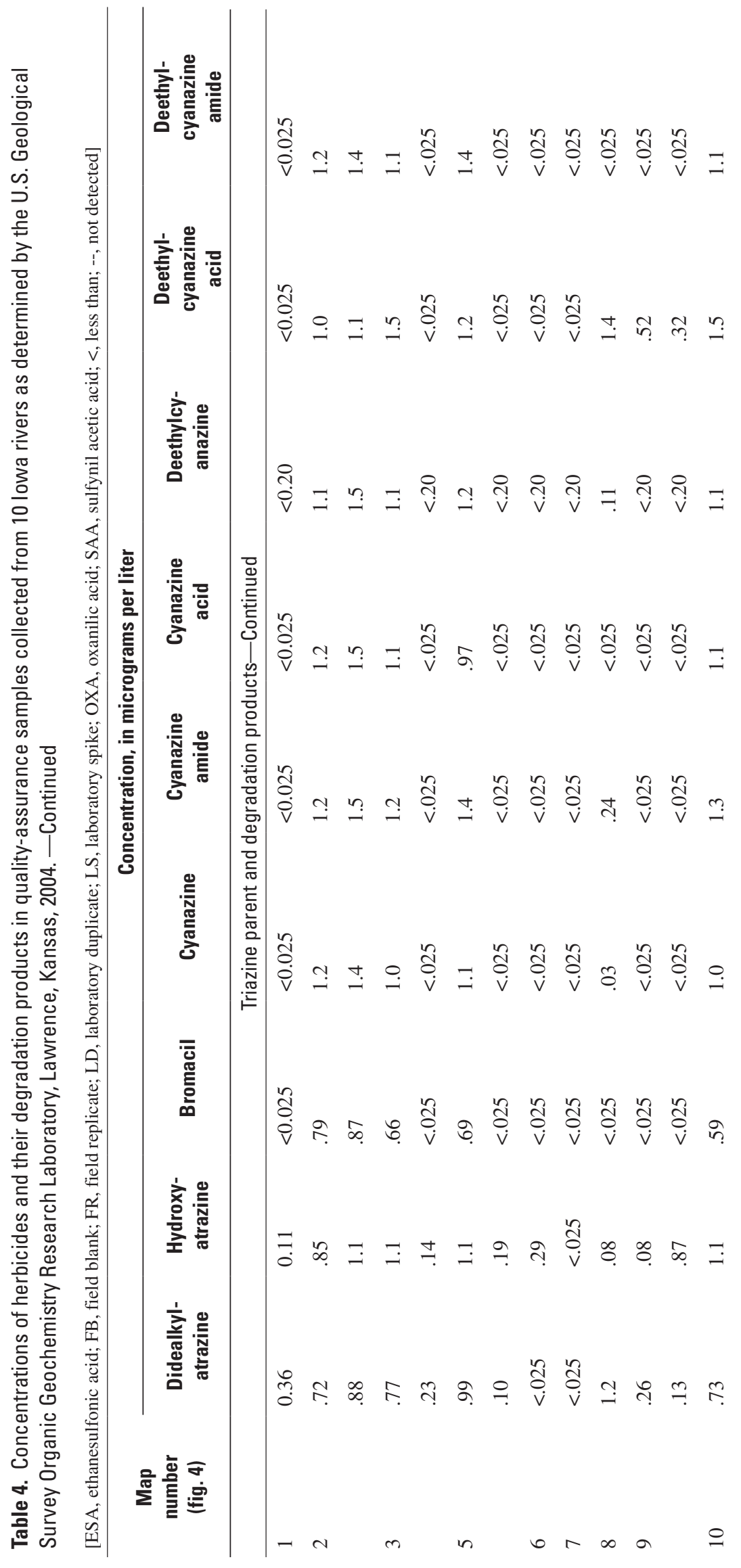




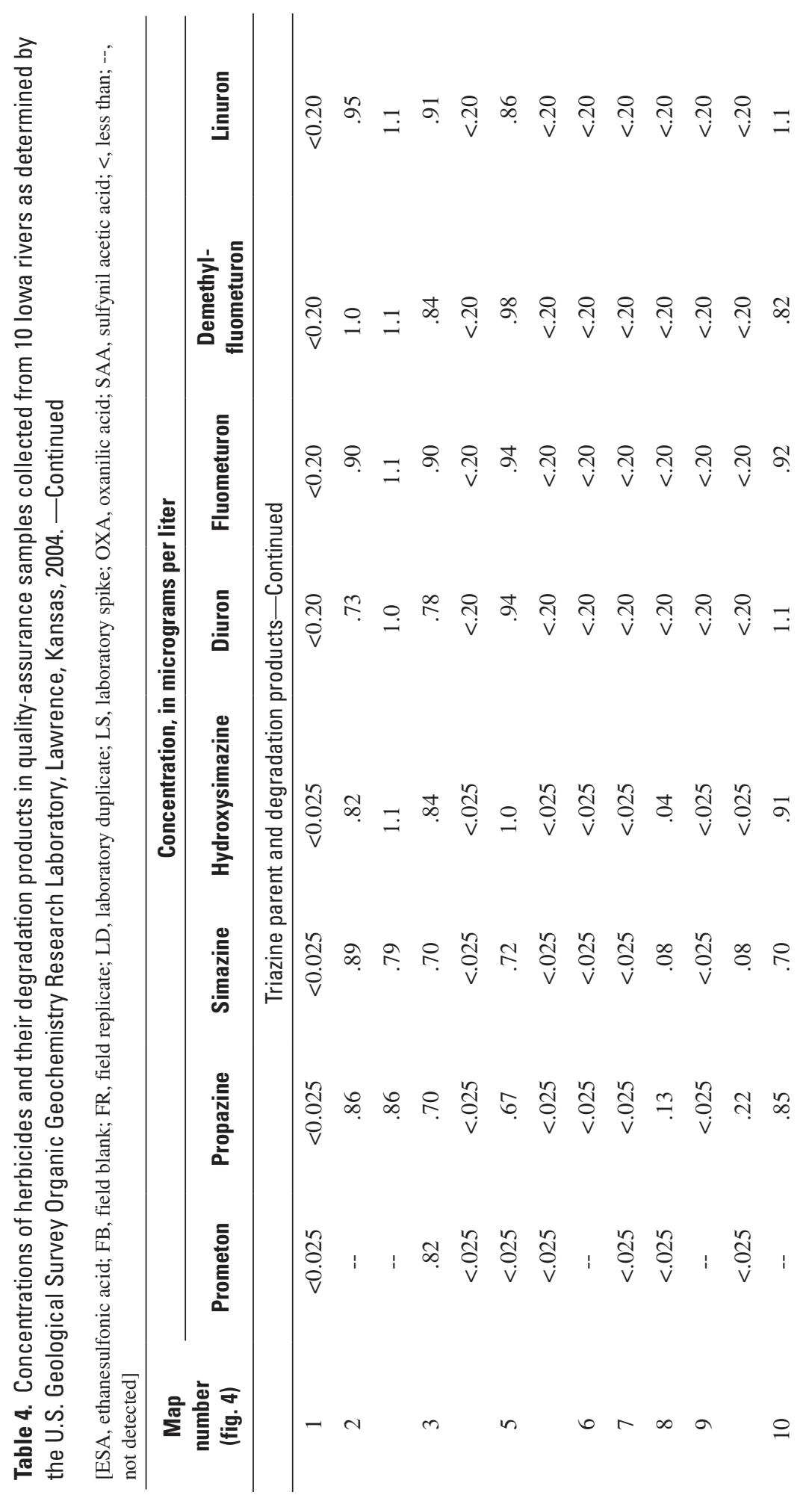




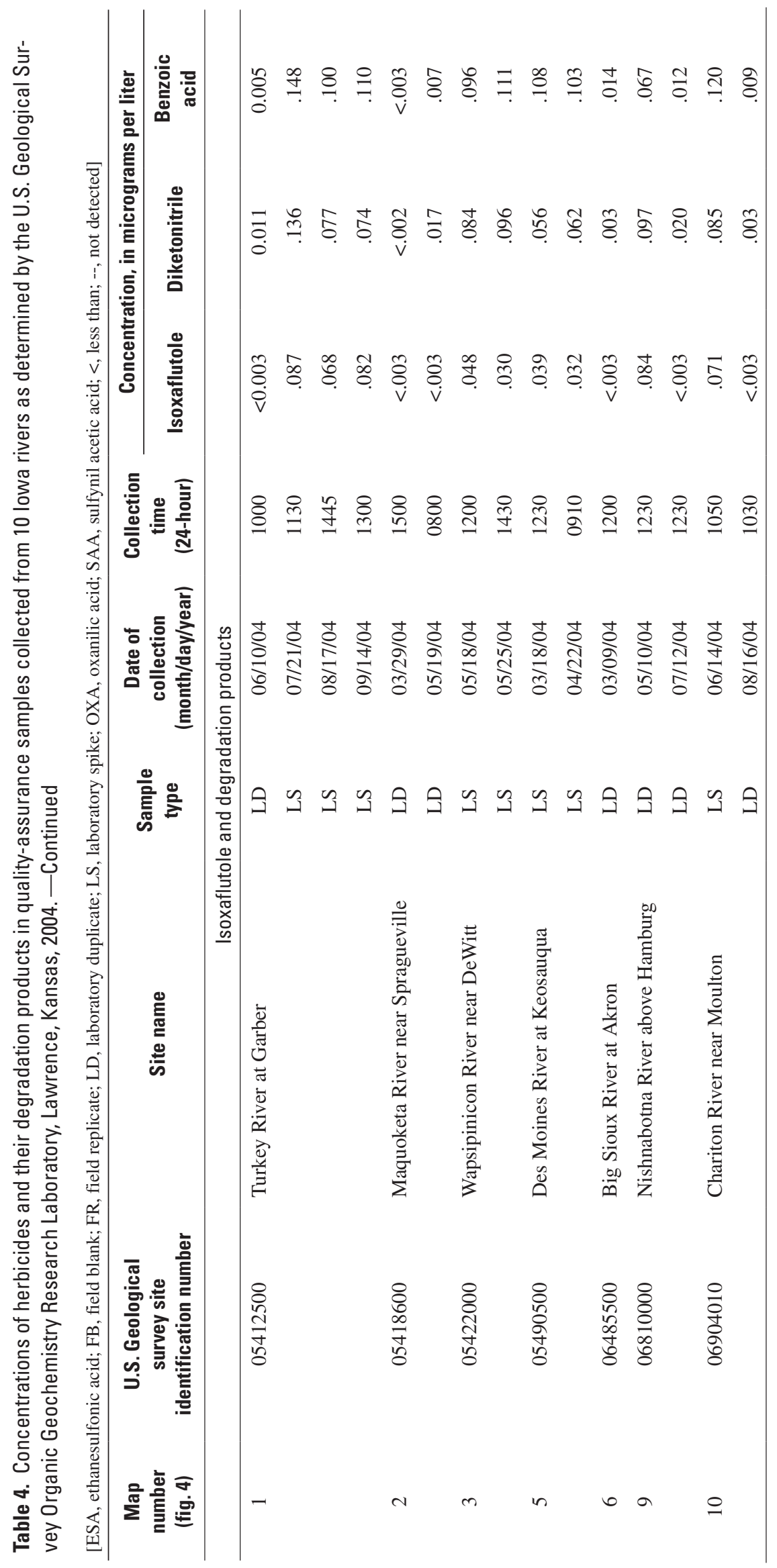


Table 5. Percentage recoveries of compounds as determined by U.S. Geological Survey National Water-Quality Laboratory, Lakewood, Colorado, using laboratory schedule 2001 for water samples collected from 10 rivers in lowa, 2004.

\begin{tabular}{|c|c|c|c|c|c|c|}
\hline \multirow{2}{*}{$\begin{array}{c}\text { Map } \\
\text { number } \\
\text { (fig. 4) }\end{array}$} & \multirow{2}{*}{$\begin{array}{l}\text { U.S. Geological } \\
\text { survey site } \\
\text { identifica- } \\
\text { tion number }\end{array}$} & \multirow[b]{2}{*}{ Site name } & \multirow{2}{*}{$\begin{array}{c}\text { Date of } \\
\text { collection } \\
\text { (month/day/ } \\
\text { year) }\end{array}$} & \multirow{2}{*}{$\begin{array}{l}\text { Collection } \\
\text { time } \\
\text { (24-hour) }\end{array}$} & \multicolumn{2}{|c|}{ Percentage recovery } \\
\hline & & & & & alpha-HCH-d 6 & Diazinon- $_{10}$ \\
\hline \multirow[t]{8}{*}{1} & 05412500 & Turkey River at Garber & $03 / 15 / 04$ & 1100 & 105 & 113 \\
\hline & & & 04/20/04 & 0950 & 96 & 120 \\
\hline & & & $05 / 19 / 04$ & 1200 & 93 & 120 \\
\hline & & & $05 / 24 / 04$ & 1100 & 98 & 127 \\
\hline & & & $06 / 10 / 04$ & 1000 & 100 & 114 \\
\hline & & & $07 / 21 / 04$ & 1130 & 89 & 102 \\
\hline & & & 08/17/04 & 1445 & 92 & 102 \\
\hline & & & $09 / 14 / 04$ & 1300 & 92 & 105 \\
\hline \multirow[t]{9}{*}{2} & 05418600 & Maquoketa River near Spragueville & 03/15/04 & 1700 & 107 & 117 \\
\hline & & & $03 / 29 / 04$ & 1500 & 101 & 118 \\
\hline & & & 04/20/04 & 1510 & 108 & 131 \\
\hline & & & $05 / 19 / 04$ & 0800 & 93 & 117 \\
\hline & & & $05 / 25 / 04$ & 1000 & 95 & 122 \\
\hline & & & 06/10/04 & 1300 & 101 & 115 \\
\hline & & & $07 / 21 / 04$ & 0720 & 92 & 104 \\
\hline & & & 08/17/04 & 1025 & 92 & 91 \\
\hline & & & $09 / 14 / 04$ & 1000 & 91 & 101 \\
\hline \multirow[t]{8}{*}{3} & 05422000 & Wapsipinicon River near DeWitt & 03/17/04 & 0830 & 109 & 125 \\
\hline & & & $04 / 15 / 04$ & 0830 & 99 & 118 \\
\hline & & & $05 / 18 / 05$ & 1200 & 91 & 121 \\
\hline & & & $05 / 25 / 04$ & 1400 & 100 & 128 \\
\hline & & & $06 / 16 / 04$ & 1230 & 94 & 117 \\
\hline & & & $07 / 20 / 94$ & 1200 & 93 & 98 \\
\hline & & & 08/17/04 & 0745 & 89 & 95 \\
\hline & & & $09 / 14 / 04$ & 0730 & 94 & 103 \\
\hline \multirow[t]{5}{*}{4} & 05474000 & Skunk River at Augusta & 03/17/04 & 1430 & 105 & 119 \\
\hline & & & $04 / 15 / 04$ & 1345 & 96 & 112 \\
\hline & & & 05/18/04 & 0730 & 94 & 117 \\
\hline & & & $06 / 16 / 04$ & 0900 & 95 & 121 \\
\hline & & & $07 / 20 / 04$ & 0800 & 94 & 101 \\
\hline
\end{tabular}


Table 5. Percentage recoveries of compounds as determined by U.S. Geological Survey National Water-Quality Laboratory, Lakewood, Colorado, using laboratory schedule 2001 for water samples collected from 10 rivers in lowa, 2004.-Continued

\begin{tabular}{|c|c|c|c|c|c|c|}
\hline \multirow{2}{*}{$\begin{array}{c}\text { Map } \\
\text { number } \\
\text { (fig. 4) }\end{array}$} & \multirow{2}{*}{$\begin{array}{l}\text { U.S. Geological } \\
\text { survey site } \\
\text { identifica- } \\
\text { tion number }\end{array}$} & \multirow[b]{2}{*}{ Site name } & \multirow{2}{*}{$\begin{array}{c}\text { Date of } \\
\text { collection } \\
\text { (month/day/ } \\
\text { year) }\end{array}$} & \multirow{2}{*}{$\begin{array}{l}\text { Collection } \\
\text { time } \\
\text { (24-hour) }\end{array}$} & \multicolumn{2}{|c|}{ Percentage recovery } \\
\hline & & & & & alpha-HCH-d ${ }_{6}$ & Diazinon- $d_{10}$ \\
\hline \multirow[t]{2}{*}{4} & 05474000 & Skunk River at Augusta & $08 / 16 / 04$ & 1615 & 91 & 105 \\
\hline & & & 09/13/04 & 1530 & 93 & 101 \\
\hline \multirow[t]{7}{*}{5} & 05490500 & Des Moines River at Keosauqua & $03 / 18 / 04$ & 1230 & 108 & 118 \\
\hline & & & $04 / 22 / 04$ & 0910 & 98 & 122 \\
\hline & & & 05/17/04 & 1400 & 94 & 115 \\
\hline & & & $06 / 14 / 04$ & 1400 & 95 & 119 \\
\hline & & & 07/19/04 & 1600 & 97 & 104 \\
\hline & & & 08/16/04 & 1330 & 84 & 95 \\
\hline & & & 09/13/04 & 1330 & 95 & 99 \\
\hline \multirow[t]{9}{*}{6} & 06485500 & Big Sioux River at Akron & 0309/04 & 1200 & 110 & 130 \\
\hline & & & 04/13/04 & 0930 & 102 & 122 \\
\hline & & & $05 / 12 / 04$ & 1030 & 98 & 116 \\
\hline & & & $05 / 26 / 04$ & 1300 & 102 & 124 \\
\hline & & & 06/02/04 & 1215 & 96 & 98 \\
\hline & & & $07 / 14 / 04$ & 1030 & 88 & 97 \\
\hline & & & 08/11/04 & 0940 & 94 & 110 \\
\hline & & & 09/08/04 & 0730 & 93 & 98 \\
\hline & & & 09/17/04 & 1230 & 85 & 98 \\
\hline \multirow[t]{10}{*}{7} & 06607500 & Little Sioux River near Turin & 03/10/04 & 0830 & 114 & 125 \\
\hline & & & 04/13/04 & 1400 & 100 & 113 \\
\hline & & & $05 / 11 / 04$ & 1020 & 97 & 114 \\
\hline & & & $05 / 24 / 04$ & 1100 & 99 & 122 \\
\hline & & & 06/08/04 & 0850 & 95 & 108 \\
\hline & & & $06 / 17 / 04$ & 1230 & 104 & 124 \\
\hline & & & 07/13/04 & 1000 & 85 & 102 \\
\hline & & & 08/10/04 & 0900 & 83 & 90 \\
\hline & & & 09/08/04 & 1100 & 90 & 96 \\
\hline & & & 09/20/04 & 1145 & 86 & 102 \\
\hline
\end{tabular}


Table 5. Percentage recoveries of compounds as determined by U.S. Geological Survey National Water-Quality Laboratory, Lakewood, Colorado, using laboratory schedule 2001 for water samples collected from 10 rivers in lowa, 2004.—Continued

\begin{tabular}{|c|c|c|c|c|c|c|}
\hline \multirow{2}{*}{$\begin{array}{c}\text { Map } \\
\text { number } \\
\text { (fig. 4) }\end{array}$} & \multirow{2}{*}{$\begin{array}{l}\text { U.S. Geological } \\
\text { survey site } \\
\text { identifica- } \\
\text { tion number }\end{array}$} & \multirow[b]{2}{*}{ Site name } & \multirow{2}{*}{$\begin{array}{c}\text { Date of } \\
\text { collection } \\
\text { (month/day/ } \\
\text { year) }\end{array}$} & \multirow{2}{*}{$\begin{array}{l}\text { Collection } \\
\text { time } \\
\text { (24-hour) }\end{array}$} & \multicolumn{2}{|c|}{ Percentage recovery } \\
\hline & & & & & alpha-HCH-d ${ }_{6}$ & Diazinon- $\mathrm{d}_{10}$ \\
\hline \multirow[t]{9}{*}{8} & 06609500 & Boyer River at Logan & $03 / 12 / 04$ & 0930 & 109 & 117 \\
\hline & & & $04 / 14 / 04$ & 0730 & 102 & 118 \\
\hline & & & $05 / 11 / 04$ & 1300 & 98 & 108 \\
\hline & & & $05 / 23 / 04$ & 1015 & 93 & 121 \\
\hline & & & 06/08/04 & 1130 & 95 & 105 \\
\hline & & & $06 / 17 / 04$ & 1000 & 103 & 125 \\
\hline & & & 07/13/04 & 1230 & 58 & 65 \\
\hline & & & 08/10/04 & 1130 & 96 & 116 \\
\hline & & & 09/07/04 & 1530 & 93 & 96 \\
\hline \multirow[t]{9}{*}{9} & 06810000 & Nishnabotna River above Hamburg & 03/11/04 & 1030 & 106 & 115 \\
\hline & & & $03 / 29 / 04$ & 1230 & 92 & 115 \\
\hline & & & $04 / 12 / 04$ & 1300 & 97 & 114 \\
\hline & & & $05 / 10 / 04$ & 1230 & 90 & 113 \\
\hline & & & $05 / 15 / 04$ & 1045 & 95 & 122 \\
\hline & & & 06/07/04 & 1245 & 96 & 109 \\
\hline & & & $07 / 12 / 04$ & 1230 & 78 & 107 \\
\hline & & & 08/09/04 & 1230 & 91 & 106 \\
\hline & & & 09/07/04 & 1230 & 93 & 98 \\
\hline \multirow[t]{7}{*}{10} & 06904010 & Chariton River near Moulton & $03 / 18 / 04$ & 0900 & 108 & 120 \\
\hline & & & $04 / 22 / 04$ & 1320 & 101 & 128 \\
\hline & & & $05 / 17 / 04$ & 1100 & 96 & 121 \\
\hline & & & $06 / 14 / 04$ & 1050 & 98 & 120 \\
\hline & & & $07 / 19 / 04$ & 1230 & 98 & 115 \\
\hline & & & 08/16/04 & 1030 & 90 & 102 \\
\hline & & & 09/13/04 & 1030 & 88 & 93 \\
\hline
\end{tabular}


Table 6. Summary of number and percentage of detections of herbicides and their degradation products analyzed by the U.S. Geological Survey Organic Research Laboratory, Lawrence, Kansas, for water samples collected from 10 rivers in lowa, 2004.

[ESA, ethanesulfonic acid; OXA, oxanilic acid; SAA, sulfynil acetic acid; n, number of samples]

\begin{tabular}{|c|c|c|c|c|c|c|}
\hline \multirow[b]{2}{*}{ Herbicide compound } & \multicolumn{3}{|c|}{ Number of detections } & \multicolumn{3}{|c|}{ Percentage of detections } \\
\hline & $\begin{array}{c}\text { Pre- } \\
\text { planting } \\
\text { (March- } \\
\text { April) }\end{array}$ & $\begin{array}{c}\text { Post- } \\
\text { planting } \\
\text { (May-June) }\end{array}$ & $\begin{array}{c}\text { Late } \\
\text { summer } \\
\text { (July-Sept.) }\end{array}$ & $\begin{array}{c}\text { Pre- } \\
\text { planting } \\
\text { (March- } \\
\text { April) }\end{array}$ & $\begin{array}{c}\text { Post- } \\
\text { planting } \\
\text { (May-June) }\end{array}$ & $\begin{array}{c}\text { Late } \\
\text { summer } \\
\text { (July-Sept.) }\end{array}$ \\
\hline \multicolumn{7}{|c|}{ Isoxaflutole parent and degradation products } \\
\hline & $\mathrm{n}=21$ & $\mathrm{n}=27$ & $\mathrm{n}=27$ & $\mathrm{n}=21$ & $\mathrm{n}=27$ & $\mathrm{n}=27$ \\
\hline Diketonitrile & 13 & 27 & 16 & 62 & 100 & 59 \\
\hline Benzoic acid & 7 & 23 & 13 & 33 & 85 & 48 \\
\hline \multicolumn{7}{|c|}{ Acetamide parent and degradation products } \\
\hline & $\mathrm{n}=21$ & $\mathrm{n}=29$ & $\mathrm{n}=10$ & $\mathrm{n}=21$ & $\mathrm{n}=29$ & $\mathrm{n}=10$ \\
\hline Acetochlor hydroxy & 0 & 0 & 4 & 0 & 0 & 40 \\
\hline Acetochlor OXA & 21 & 29 & 10 & 100 & 100 & 100 \\
\hline Acetochlor SAA & 15 & 27 & 6 & 71 & 93 & 60 \\
\hline Acetochlor/metolachlor 2nd amide & 0 & 8 & 0 & 0 & 28 & 0 \\
\hline Acetochlor/metolachlor ESA 2nd amide & 20 & 28 & 10 & 95 & 97 & 100 \\
\hline Alachlor & 0 & 3 & 0 & 0 & 10 & 0 \\
\hline Alachlor ESA & 21 & 26 & 9 & 100 & 90 & 90 \\
\hline Dimethenamid deschloro & 0 & 1 & 0 & 0 & 3 & 0 \\
\hline Dimethenamid ESA & 14 & 22 & 7 & 67 & 76 & 70 \\
\hline Dimethenamid OXA & 6 & 18 & 5 & 29 & 62 & 50 \\
\hline Flufenacet & 1 & 14 & 0 & 5 & 48 & 0 \\
\hline Flufenacet ESA & 2 & 6 & 0 & 10 & 21 & 0 \\
\hline Flufenacet OXA & 0 & 5 & 0 & 0 & 17 & 0 \\
\hline Metolachlor & 20 & 29 & 10 & 95 & 100 & 100 \\
\hline Metolachlor deschloro & 0 & 2 & 1 & 0 & 7 & 10 \\
\hline Metolachlor ESA & 21 & 29 & 10 & 100 & 100 & 100 \\
\hline Metolachlor OXA & 21 & 29 & 10 & 100 & 100 & 100 \\
\hline Metolachlor hydroxy & 0 & 0 & 4 & 0 & 0 & 40 \\
\hline
\end{tabular}


Table 6. Summary of number and percentage of detections of herbicides and their degradation products analyzed by the U.S. Geological Survey Organic Research Laboratory, Lawrence, Kansas, for water samples collected from 10 rivers in lowa, 2004.Continued

[ESA, ethanesulfonic acid; OXA, oxanilic acid; SAA, sulfynil acetic acid; n, number of samples]

\begin{tabular}{|c|c|c|c|c|c|c|}
\hline \multirow[b]{2}{*}{ Herbicide compound } & \multicolumn{3}{|c|}{ Number of detections } & \multicolumn{3}{|c|}{ Percentage of detections } \\
\hline & $\begin{array}{c}\text { Pre- } \\
\text { planting } \\
\text { (March- } \\
\text { April) }\end{array}$ & $\begin{array}{c}\text { Post- } \\
\text { planting } \\
\text { (May-June) }\end{array}$ & $\begin{array}{c}\text { Late } \\
\text { summer } \\
\text { (July-Sept.) }\end{array}$ & $\begin{array}{c}\text { Pre- } \\
\text { planting } \\
\text { (March- } \\
\text { April) }\end{array}$ & $\begin{array}{c}\text { Post- } \\
\text { planting } \\
\text { (May-June) }\end{array}$ & $\begin{array}{c}\text { Late } \\
\text { summer } \\
\text { (July-Sept.) }\end{array}$ \\
\hline \multicolumn{7}{|c|}{ Triazine parent and degradation products } \\
\hline & $\mathrm{n}=22$ & $\mathrm{n}=29$ & $\mathrm{n}=16$ & $\mathrm{n}=22$ & $\mathrm{n}=29$ & $\mathrm{n}=16$ \\
\hline Atrazine & 19 & 29 & 16 & 86 & 100 & 100 \\
\hline Deethylatrazine & 20 & 29 & 16 & 91 & 100 & 100 \\
\hline Deethylhydroxyatrazine & 0 & 2 & 0 & 0 & 7 & 0 \\
\hline Deisopropylatrazine & 7 & 29 & 14 & 32 & 100 & 88 \\
\hline Deisopropylhydroxyatrazine & 0 & 2 & 1 & 0 & 7 & 6 \\
\hline Didealkylatrazine & 21 & 29 & 12 & 95 & 100 & 75 \\
\hline Hydroxyatrazine & 21 & 29 & 10 & 95 & 100 & 63 \\
\hline Cyanazine & 0 & 1 & 0 & 0 & 3 & 0 \\
\hline Deethylcyanazine acid & 11 & 12 & 3 & 50 & 41 & 19 \\
\hline Propazine & 0 & 10 & 0 & 0 & 34 & 0 \\
\hline Simazine & 1 & 9 & 1 & 5 & 31 & 6 \\
\hline
\end{tabular}

22 (86 percent) preplanting (March-April) samples analyzed by the triazine herbicide method, 29 of 29 (100 percent) postplanting (May-June) samples, and 16 of 16 (100 percent) late summer (July-September) samples (table 6). Deethylatrazine (91 percent detection) occurred more frequently than atrazine ( 86 percent) in the preplanting-season samples, and both compounds were detected in all samples during the latesummer season. As can be seen in table 6, three other atrazine degradation products, deisopropylatrazine (32/100/88 percent), didealkylatrazine (95/100/75 percent), and hydroxyatrazine (95/100/63 percent), also occurred frequently during the three seasons in the 10 Iowa rivers sampled.

As shown in figure 8 and in table 9 at the back of this report, atrazine was not only the most frequently detected herbicide but also had the maximum concentration of $21 \mu \mathrm{g} / \mathrm{L}$ during the postplanting season. This maximum concentration occurred in a sample from the Nishnabotna River above Hamburg, Iowa (fig. 4). The atrazine degradation products deethylatrazine, didealkylatrazine, and hydroxyatrazine also were detected frequently during all three seasons. It is of importance to note that deethylcyanazine acid, a degradation product of cyanazine, also was detected during all three sampling seasons (table 6). The manufacture of cyanazine was discontinued on December 31, 1999, but the hydrologic system still contains the "fingerprint" of past cyanazine use.
There were no detections for the uracil herbicide, bromacil, nor the triazine degradation products, cyanazine amide, cyanazine acid, and deethylcyanazine amide. The triazine method used in this study also analyzes for three phenylurea herbicides, diuron, fluometuron, and linuron, and one degradation product, demethylfluometuron. There were no detections of the phenylurea parent compounds nor the degradation product, demethylfluometuron.

Analytical results for concentrations of selected pesticides and their degradation products determined by the USGS NWQL schedule 2001 are shown in table 10 at the back of this report. NWQL schedule 2001 (table 3) contains 52 parent pesticides and degradation products. Twenty-eight pesticide herbicides were detected above various reporting limits (table 10). Atrazine, deethylatrazine, a triazine degradation product, and metolachlor were detected in all of the 106 analyzed water samples. The highest concentration was atrazine with an estimated concentration of $42 \mu \mathrm{g} / \mathrm{L}$, followed by metolachlor with a concentration of $3.9 \mu \mathrm{g} / \mathrm{L}$, and deethylatrazine with an estimated concentration of $0.67 \mu \mathrm{g} / \mathrm{L}$.

This study reaffirms several previous findings of herbicides and their degradation products from the 1980s through the mid-1990s, including the fact that large concentrations of herbicides were flushed from cropland and transported in response to late spring and early summer rainfall and that 


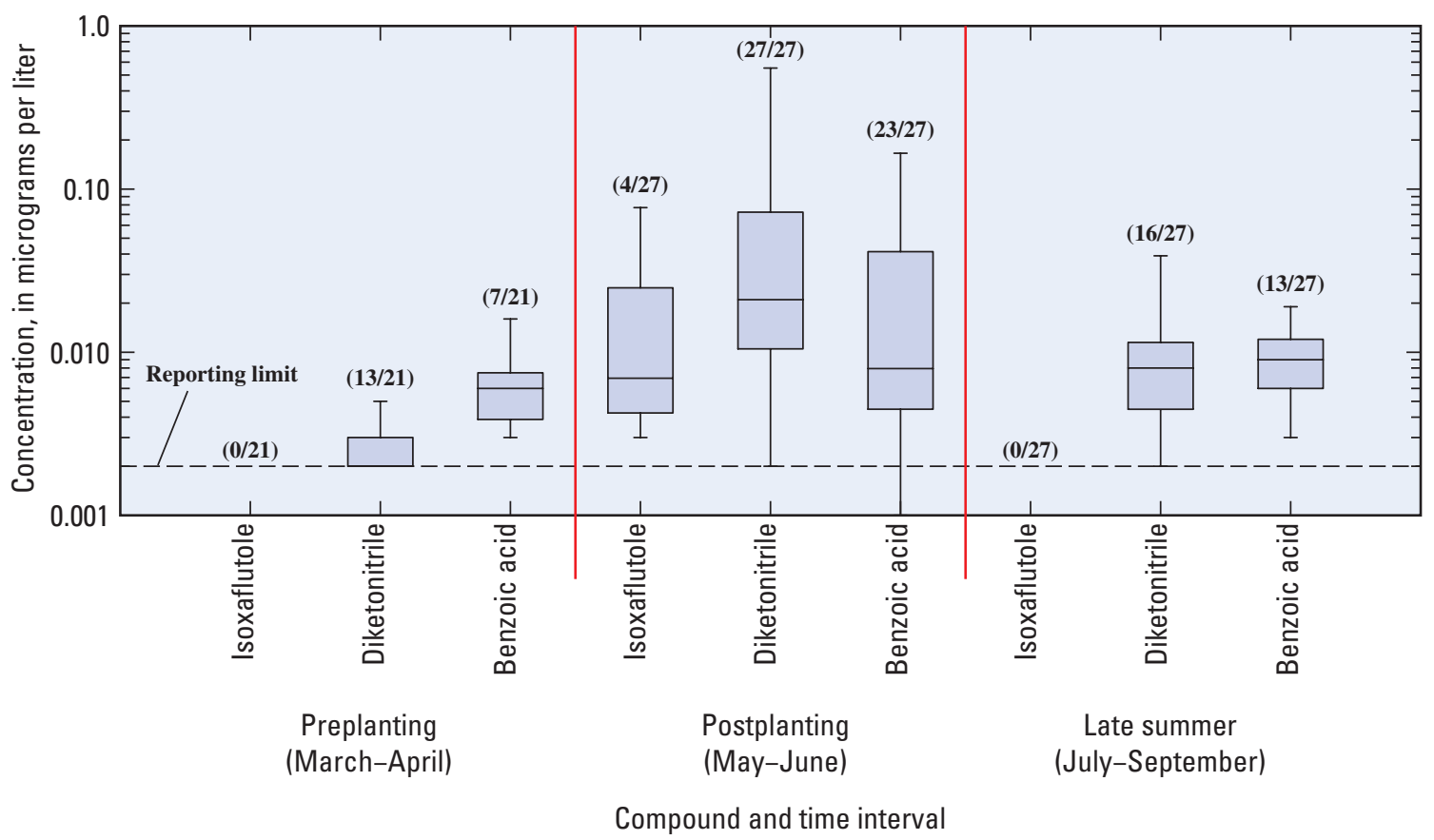

\section{EXPLANATION}

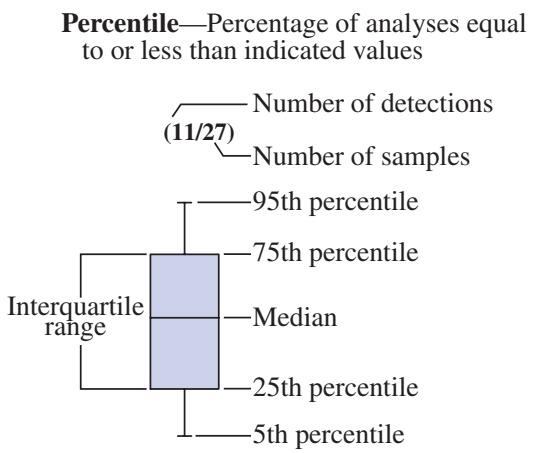

Figure 6. Concentrations of isoxaflutole, diketonitrile, and benzoic acid in water samples collected from 10 rivers in lowa, 2004.

herbicides and their degradation products were detected year round in streams (Thurman and others, 1991, 1992, 1994; Scribner and others, 1993, 1998, 2000a,b, 2005; Meyer and others, 1996; Thurman and Fallon, 1996; Schnoebelen and others, 2003).

Another significant finding of this study comparable to previous studies revealed that herbicide degradation products commonly were detected as frequently or more frequently than their parent herbicide. These data agree with past studies of Iowa ground water and rivers (Kolpin and others, 1996, 1997, 1998, 2000, 2001, 2004; Kalkhoff and others, 1998, 2003; Battaglin and others, 2003, 2005; Scribner and others, 2004).

Isoxaflutole is applied in Iowa at a rate that is 8 percent of the rate of atrazine application and 4 percent of the rate of metolachlor application and is only applied to 24 percent of the number of acres to which atrazine is applied (U.S. Department of Agriculture, 2004). Thus, the frequent detection of the herbicidally active degradation product of isoxaflutole, diketonitrile, and its degradation product, benzoic acid, was unexpected.

The water-quality data resulting from this study are important to understanding effects of herbicides on the surface-water resources locally in Iowa and nationally in the Mississippi and Missouri Rivers. The data also can be used to provide information so that decisions regarding the development, management, and protection of these resources may be improved. 
Table 7. Concentrations of isoxaflutole and two degradation products analyzed by the U.S. Geological Survey Organic Geochemistry Research Laboratory, Lawrence, Kansas, for water samples collected from 10 rivers in lowa, 2004.

$[<$, less than $]$

\begin{tabular}{|c|c|c|c|c|c|c|c|}
\hline \multirow{2}{*}{$\begin{array}{c}\text { Map } \\
\text { number } \\
\text { (fig. 4) }\end{array}$} & \multirow{2}{*}{$\begin{array}{c}\text { U.S. Geological } \\
\text { Survey site } \\
\text { identification } \\
\text { number }\end{array}$} & \multirow{2}{*}{ Site name } & \multirow{2}{*}{$\begin{array}{c}\text { Date of } \\
\text { collection } \\
\text { (month/day/ } \\
\text { year) }\end{array}$} & \multirow{2}{*}{$\begin{array}{l}\text { Collection } \\
\text { Time } \\
\text { (24-hour) }\end{array}$} & \multicolumn{3}{|c|}{$\begin{array}{c}\text { Concentration, } \\
\text { in micrograms per liter }\end{array}$} \\
\hline & & & & & $\begin{array}{l}\text { Isoxa- } \\
\text { flutole }\end{array}$ & $\begin{array}{l}\text { Diketo- } \\
\text { nitrile }\end{array}$ & $\begin{array}{l}\text { Benzoic } \\
\text { acid }\end{array}$ \\
\hline \multirow[t]{8}{*}{1} & 05412500 & Turkey River at Garber & $03 / 15 / 04$ & 1100 & $<0.003$ & $<0.002$ & $<0.003$ \\
\hline & & & $04 / 20 / 04$ & 0950 & $<.003$ & $<.002$ & $<.003$ \\
\hline & & & 05/19/04 & 1200 & $<.003$ & .035 & .006 \\
\hline & & & 05/24/04 & 1115 & $<.003$ & .092 & .050 \\
\hline & & & 06/10/04 & 1000 & $<.003$ & .010 & .005 \\
\hline & & & $07 / 21 / 04$ & 1130 & $<.003$ & .004 & $<.003$ \\
\hline & & & 08/17/04 & 1445 & $<.003$ & $<.002$ & $<.003$ \\
\hline & & & 09/14/04 & 1300 & $<.003$ & $<.002$ & $<.003$ \\
\hline \multirow[t]{9}{*}{2} & 05418600 & Maquoketa River near & 03/15/04 & 1700 & $<.003$ & $<.005$ & $<.003$ \\
\hline & & Sprague & $03 / 29 / 04$ & 1500 & $<.003$ & $<.002$ & $<.003$ \\
\hline & & & $04 / 20 / 04$ & 1510 & $<.003$ & $<.002$ & $<.003$ \\
\hline & & & 05/19/04 & 0800 & $<.003$ & .015 & .005 \\
\hline & & & $05 / 25 / 04$ & 1015 & $<.003$ & .010 & .005 \\
\hline & & & 06/10/04 & 1300 & $<.003$ & .003 & $<.003$ \\
\hline & & & $07 / 21 / 04$ & 0720 & $<.003$ & $<.002$ & $<.003$ \\
\hline & & & 08/17/04 & 1025 & $<.003$ & $<.002$ & $<.003$ \\
\hline & & & 09/14/04 & 1000 & $<.003$ & $<.002$ & $<.003$ \\
\hline \multirow[t]{9}{*}{3} & 05422000 & Wapsipinicon River near DeWitt & 03/17/04 & 0830 & $<.003$ & .002 & .005 \\
\hline & & & $04 / 15 / 04$ & 0830 & $<.003$ & $<.002$ & $<.003$ \\
\hline & & & 05/18/04 & 1140 & $<.003$ & .002 & $<.003$ \\
\hline & & & 05/18/04 & 1200 & $<.003$ & .007 & .003 \\
\hline & & & $05 / 25 / 04$ & 1430 & $<.003$ & .027 & .013 \\
\hline & & & $06 / 16 / 04$ & 1230 & $<.003$ & .018 & .009 \\
\hline & & & 07/20/04 & 1200 & $<.003$ & .017 & .012 \\
\hline & & & 08/17/04 & 0745 & $<.003$ & .002 & $<.003$ \\
\hline & & & 09/14/04 & 0730 & $<.003$ & .010 & $<.003$ \\
\hline \multirow[t]{3}{*}{4} & 05474000 & Skunk River at Augusta & 03/17/04 & 1430 & $<.003$ & .002 & $<.003$ \\
\hline & & & $04 / 15 / 04$ & 1345 & $<.003$ & $<.002$ & $<.003$ \\
\hline & & & 05/18/04 & 0730 & $<.003$ & .036 & .006 \\
\hline
\end{tabular}


Table 7. Concentrations of isoxaflutole and two degradation products analyzed by the U.S. Geological Survey Organic Geochemistry Research Laboratory, Lawrence, Kansas, for water samples collected from 10 rivers in lowa, 2004.-Continued

\begin{tabular}{|c|c|c|c|c|c|c|c|}
\hline \multirow{2}{*}{$\begin{array}{c}\text { Map } \\
\text { number } \\
\text { (fig. 4) }\end{array}$} & \multirow{2}{*}{$\begin{array}{c}\text { U.S. Geological } \\
\text { Survey site } \\
\text { identification } \\
\text { number }\end{array}$} & \multirow{2}{*}{ Site name } & \multirow{2}{*}{$\begin{array}{c}\text { Date of } \\
\text { collection } \\
\text { (month/day/ } \\
\text { year) }\end{array}$} & \multirow{2}{*}{$\begin{array}{l}\text { Collection } \\
\text { Time } \\
\text { (24-hour) }\end{array}$} & \multicolumn{3}{|c|}{$\begin{array}{c}\text { Concentration, } \\
\text { in micrograms per liter }\end{array}$} \\
\hline & & & & & $\begin{array}{l}\text { Isoxa- } \\
\text { flutole }\end{array}$ & $\begin{array}{l}\text { Diketo- } \\
\text { nitrile }\end{array}$ & $\begin{array}{l}\text { Benzoic } \\
\text { acid }\end{array}$ \\
\hline \multirow[t]{4}{*}{4} & 05474000 & Skunk River at Augusta & 06/16/04 & 0900 & $<0.003$ & 0.066 & 0.101 \\
\hline & & & 07/20/04 & 0800 & $<.003$ & .008 & .003 \\
\hline & & & 08/16/04 & 1615 & $<.003$ & $<.002$ & $<.003$ \\
\hline & & & 09/13/04 & 1530 & $<.003$ & $<.002$ & $<.003$ \\
\hline \multirow[t]{7}{*}{5} & 05490500 & Des Moines River at Keosauqua & $03 / 18 / 04$ & 1230 & $<.003$ & .002 & .003 \\
\hline & & & $04 / 22 / 04$ & 0910 & $<.003$ & .002 & $<.003$ \\
\hline & & & 05/17/04 & 1400 & $<.003$ & .015 & .004 \\
\hline & & & $06 / 14 / 04$ & 1400 & $<.003$ & .100 & .038 \\
\hline & & & 07/19/04 & 1600 & $<.003$ & .039 & .014 \\
\hline & & & 08/16/04 & 1330 & $<.003$ & .002 & .006 \\
\hline & & & 09/13/04 & 1330 & $<.003$ & .010 & .019 \\
\hline \multirow[t]{7}{*}{6} & 06485500 & Big Sioux River at Akron & 03/09/04 & 1200 & $<.003$ & .003 & .016 \\
\hline & & & $04 / 13 / 04$ & 0930 & $<.003$ & $<.002$ & $<.003$ \\
\hline & & & $05 / 12 / 04$ & 1030 & $<.003$ & .007 & $<.003$ \\
\hline & & & $05 / 26 / 04$ & 1300 & $<.003$ & .042 & .016 \\
\hline & & & 07/14/04 & 1030 & $<.003$ & .006 & .008 \\
\hline & & & $08 / 11 / 04$ & 0940 & $<.003$ & $<.002$ & $<.003$ \\
\hline & & & 09/08/04 & 0730 & $<.003$ & $<.002$ & $<.003$ \\
\hline \multirow[t]{8}{*}{7} & 06607500 & Little Sioux River near Turin & $03 / 10 / 04$ & 0830 & $<.003$ & .002 & .008 \\
\hline & & & 04/13/04 & 1400 & $<.003$ & .002 & $<.003$ \\
\hline & & & $05 / 11 / 04$ & 1000 & $<.003$ & .004 & $<.003$ \\
\hline & & & $05 / 11 / 04$ & 1020 & .008 & .090 & .007 \\
\hline & & & $05 / 24 / 04$ & 1100 & .003 & .141 & .051 \\
\hline & & & 06/08/04 & 0850 & $<.003$ & .011 & .003 \\
\hline & & & 07/13/04 & 1000 & $<.003$ & .012 & .005 \\
\hline & & & 09/08/04 & 1100 & $<.003$ & $<.002$ & $<.003$ \\
\hline \multirow[t]{3}{*}{8} & 06609500 & Boyer River at Logan & $03 / 12 / 04$ & 0930 & $<.003$ & .002 & .007 \\
\hline & & & 04/14/04 & 0730 & $<.003$ & .002 & $<.003$ \\
\hline & & & $05 / 11 / 04$ & 1300 & $<.003$ & .012 & .003 \\
\hline
\end{tabular}


Table 7. Concentrations of isoxaflutole and two degradation products analyzed by the U.S. Geological Survey Organic Geochemistry Research Laboratory, Lawrence, Kansas, for water samples collected from 10 rivers in lowa, 2004._- Continued

\begin{tabular}{|c|c|c|c|c|c|c|c|}
\hline \multirow{2}{*}{$\begin{array}{c}\text { Map } \\
\text { number } \\
\text { (fig. 4) }\end{array}$} & \multirow{2}{*}{$\begin{array}{l}\text { U.S. Geological } \\
\text { Survey site } \\
\text { identification } \\
\text { number }\end{array}$} & \multirow{2}{*}{ Site name } & \multirow{2}{*}{$\begin{array}{c}\text { Date of } \\
\text { collection } \\
\text { (month/day/ } \\
\text { year) }\end{array}$} & \multirow{2}{*}{$\begin{array}{c}\text { Collection } \\
\text { Time } \\
\text { (24-hour) }\end{array}$} & \multicolumn{3}{|c|}{$\begin{array}{c}\text { Concentration, } \\
\text { in micrograms per liter }\end{array}$} \\
\hline & & & & & $\begin{array}{l}\text { Isoxa- } \\
\text { flutole }\end{array}$ & $\begin{array}{l}\text { Diketo- } \\
\text { nitrile }\end{array}$ & $\begin{array}{l}\text { Benzoic } \\
\text { acid }\end{array}$ \\
\hline \multirow[t]{4}{*}{8} & 06609500 & Boyer River at Logan & $05 / 23 / 04$ & 1015 & 0.006 & 0.552 & 0.166 \\
\hline & & & 06/08/04 & 1130 & $<.003$ & .013 & .003 \\
\hline & & & $07 / 13 / 04$ & 1230 & $<.003$ & .008 & .004 \\
\hline & & & 09/07/04 & 1330 & $<.003$ & .007 & .016 \\
\hline \multirow[t]{7}{*}{9} & 06810000 & Nishnabotna River above & 03/11/04 & 1030 & $<.003$ & .003 & .006 \\
\hline & & Hamburg & $04 / 12 / 04$ & 1300 & $<.003$ & .002 & $<.003$ \\
\hline & & & 05/10/04 & 1230 & .077 & .378 & .045 \\
\hline & & & $05 / 25 / 04$ & 1045 & $<.003$ & .079 & .048 \\
\hline & & & 06/07/04 & 1245 & $<.003$ & .010 & .006 \\
\hline & & & $07 / 12 / 04$ & 1230 & $<.003$ & .020 & .012 \\
\hline & & & 09/07/04 & 1230 & $<.003$ & .003 & $<.003$ \\
\hline \multirow[t]{6}{*}{10} & 06904010 & Chariton River near Moulton & 03/18/04 & 0900 & $<.003$ & .005 & .003 \\
\hline & & & $04 / 22 / 04$ & 1320 & $<.003$ & .003 & $<.003$ \\
\hline & & & 06/14/04 & 1050 & $<.003$ & .024 & .036 \\
\hline & & & 07/19/04 & 1230 & $<.003$ & .011 & .009 \\
\hline & & & 08/16/04 & 1030 & $<.003$ & $<.002$ & .011 \\
\hline & & & 09/13/04 & 1030 & $<.003$ & .005 & .007 \\
\hline
\end{tabular}


(A) Acetochlor and its degradation products

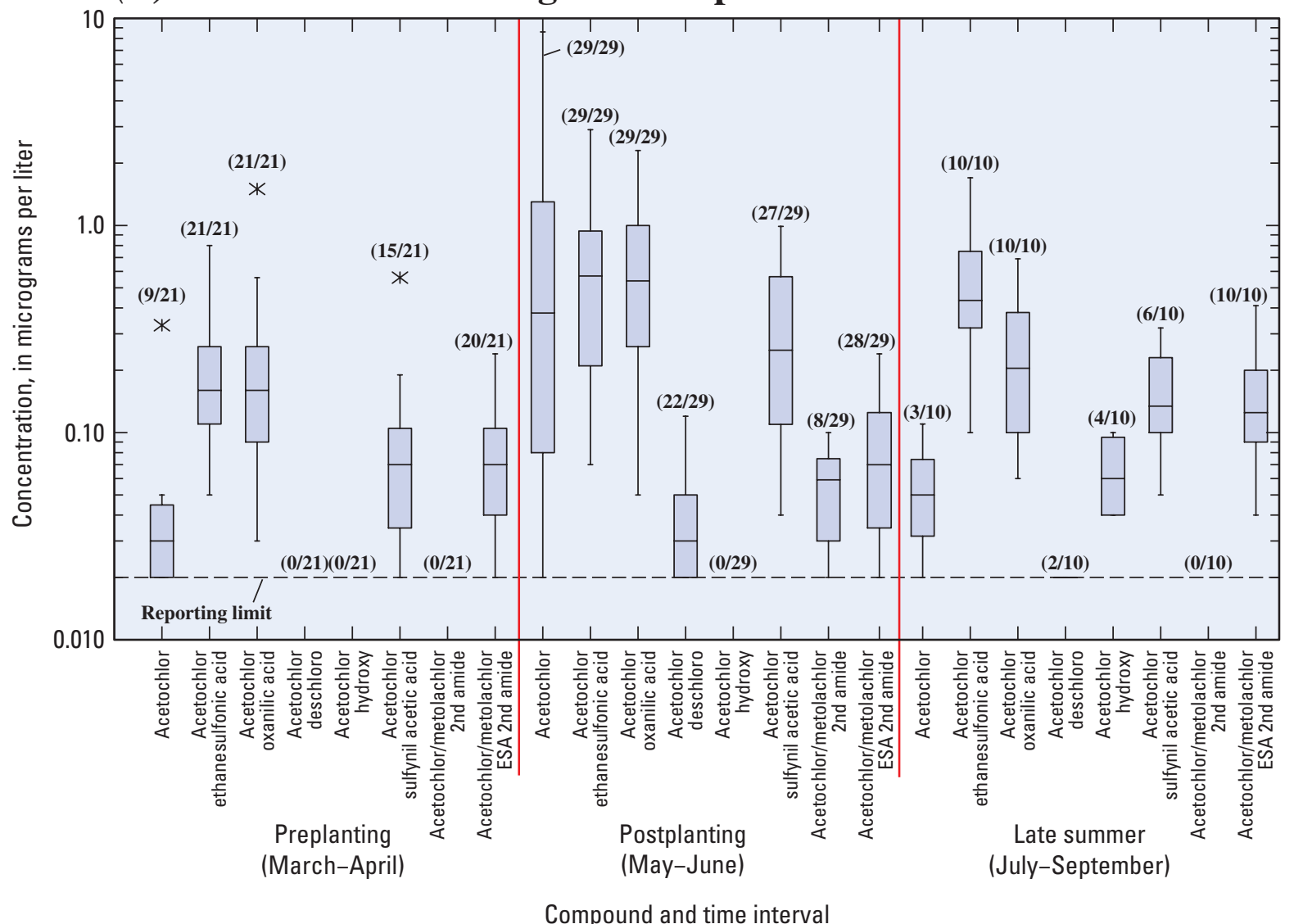

\section{EXPLANATION}

Percentile-Percentage of analyses equal to or less than indicated values

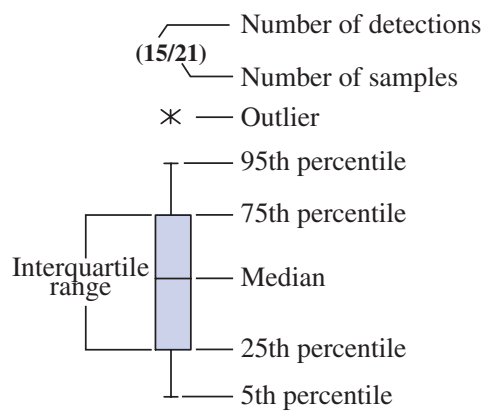

Figure 7. Concentrations of acetochlor, metolachlor, and their degradation products in water samples collected from 10 rivers in lowa, 2004. 


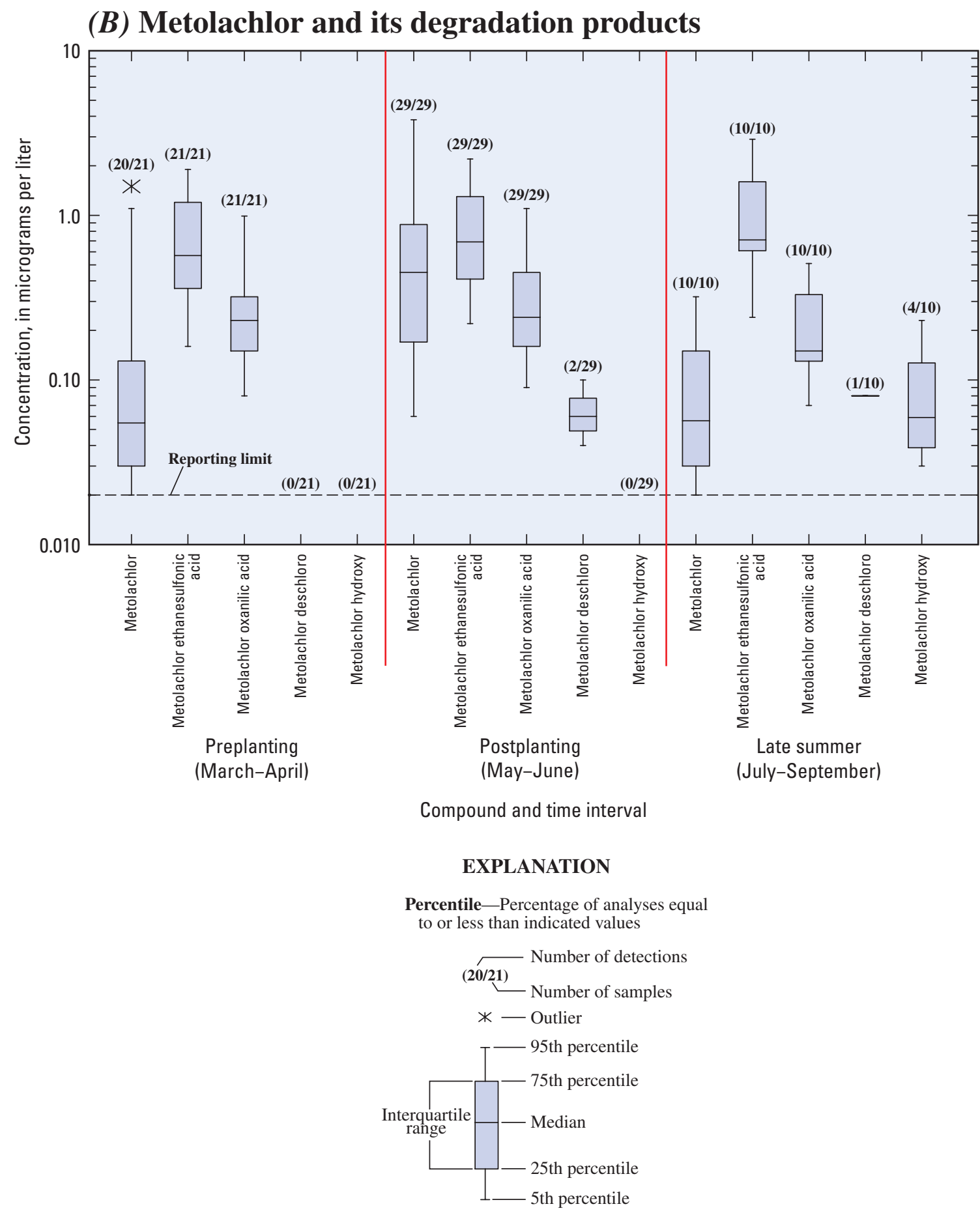

Figure 7. Concentrations of acetochlor, metolachlor, and their degradation products in water samples collected from 10 rivers in lowa, 2004. - Continued 


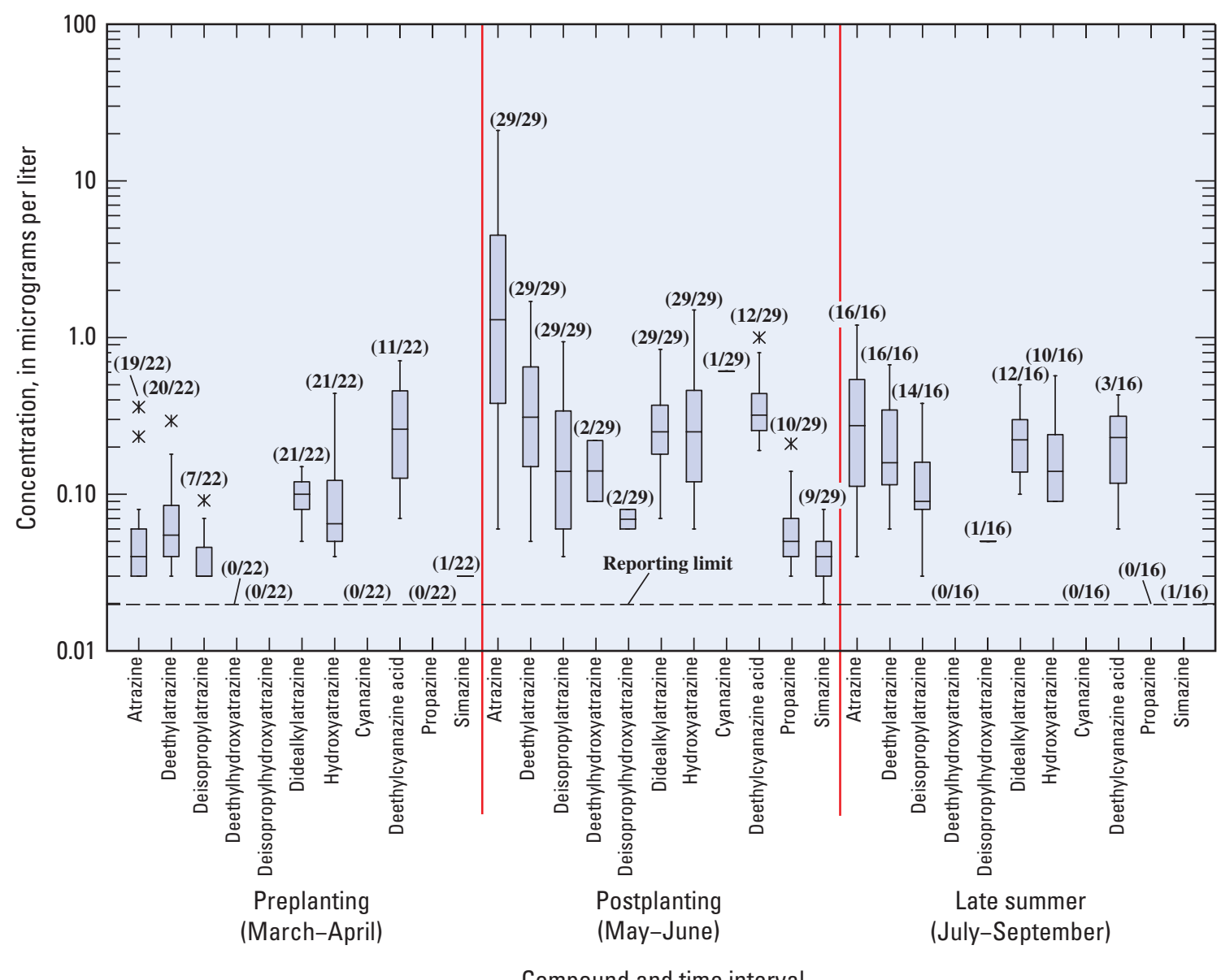

\section{EXPLANATION}

Percentile_-Percentage of analyses equal to or less than indicated values

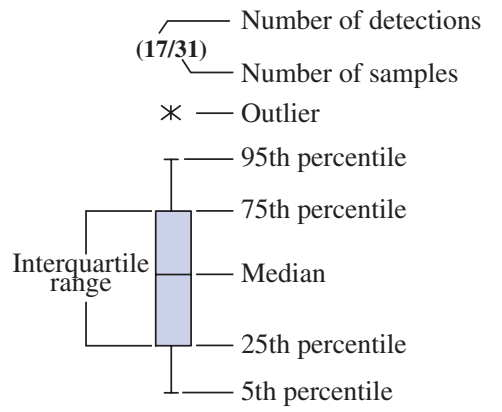

Figure 8. Concentrations of triazine herbicides and their degradation products in water samples collected from 10 rivers in lowa, 2004 


\section{Summary}

Iowa is one of the most productive agricultural areas in the United States. Pesticides are needed for crops to control competing vegetation, insects, and fungus. The use of herbicides has produced substantial crop yields.

The use of isoxaflutole, which was registered in 1998, has increased rapidly in the Midwestern United States, but there is limited understanding of its environmental fate. However, it is known that isoxaflutole degrades to a biologically active degradation product, diketonitrile, which is more stable, and further degradation of diketonitrile produces a nonbiologically active benzoic acid degradation product.

The main purpose of this report is to document the occurrence of the herbicide isoxaflutole and its degradation products from samples collected from 10 major rivers draining Iowa to the Missouri and Mississippi Rivers and to compare their occurrence with that of more commonly measured herbicides such as acetochlor, atrazine, and metolachlor. Herbicide use is one factor that affects the concentrations of herbicides measured in Midwestern rivers and a vital reason for monitoring the water quality in these rivers.

An analytical method to quantify isoxaflutole and its two degradation products was developed by the U.S. Geological Survey (USGS) Organic Geochemistry Research Laboratory using solid-phase extraction (SPE) and liquid chromatography/mass spectrometry/mass spectrometry (LC/MS/MS). Two separate methods also were used to provide the results of analysis for the occurrence of acetamide and triazine herbicides, and their degradation products. The USGS National Water-Quality Laboratory schedule 2001 was used to analyze 52 pesticides and degradation products.

Analytical results of 75 water samples show that isoxaflutole was detected in only four of the samples collected during the postplanting (May-June) season, whereas diketonitrile was detected in 56 water samples and benzoic acid was detected in 43 water samples collected from all three sampling periods. Metolachlor was the most frequently detected acetamide parent (59 of 60 samples) during all three sampling periods, followed by acetochlor (41/60). Ethanesulfonic acid and oxanilic acid degradation products of acetochlor (60/60 ESA and 60/60 OXA), alachlor (56/60 and 53/60), and metolachlor (60/60 and 60/60) were detected as frequently or more frequently than their parent compounds. Atrazine was the most detected triazine parent compound with 64 detections of 67 samples during all three sampling periods, whereas the triazine degradation products of deethylatrazine, didealkylatrazine, hydroxyatrazine, and deisopropylatrazine were detected in $65,62,61$, and 50 samples, respectively, which is similar to other reported conclusions of the detection frequency of the atrazine parent and its degradation.

Findings of the isoxaflutole study by the USGS include an improved understanding of the occurrence of the herbicide isoxaflutole and its degradation products in the hydrologic environment. Analytical results of the acetamide and triazine herbicides are consistent with previous studies, which show that large amounts of herbicides and their degradation products are flushed into streams with runoff. Also, the study confirmed previous findings that these herbicides occur as frequently or more frequently than their parent herbicide. The results of this study provide an important data set for future use.

\section{References Cited}

Battaglin, W.A., and Goolsby, D.A., 1999, Are shifts in herbicide use reflected in concentration changes in Midwestern rivers?: Environmental Science \& Technology, v. 33, p. 2917-2925.

Battaglin, W.A., Kolpin, D.W., Scribner, E.A., Kuivila, K.M., and Sandstrom, M.W., 2005, Glyphosate, other herbicides, and transformation products in Midwestern streams, 2002: Journal of the American Water Resources Association, v. 41 , no. 2 , p. 323-332.

Battaglin, W.A., Thurman, E.M., Kalkhoff, S.J., and Porter, S.D., 2003, Herbicides and transformation products in surface waters of the Midwestern United States: Journal of the American Water Resources Association, v. 39, no. 4, p. 743-756.

Benbrook, C.M., 2001, Factors shaping trends in corn herbicide use: AgBioTech InfoNet Technical Paper No. 5, Northwest Science and Environmental Policy Center, information available on the Web, accessed November 12, 2005, at http://www.biotech-info.net/corn_reduct.html

Coupe, R.H., and Goolsby, D.A., 1999, Monitoring the water quality of the Nation's large rivers: U.S. Geological Survey Fact Sheet 055-99, 6 p.

Gilliom, R.J., and Hamilton, P.A., 2006, Pesticides in the Nation's streams and ground water, 1992-2001 - a summary: U.S. Geological Survey Fact Sheet 2006-3028, 6 p.

Gilliom, R.J., and others, 2006, The quality of our Nation's water-pesticides in the Nation's streams and ground water, 1992-2001: U.S. Geological Survey Circular 1291, 172 p.

Hooper, R.P., Goolsby, D.A., Rickert, D.A., and McKenzie, S.W., 1997, A river-basin perspective on monitoring water quality: U.S. Geological Survey Fact Sheet 055-97, 6 p.

Iowa Department of Natural Resources, 2001, A plan for monitoring Iowa's waters: Geological Survey Bureau, Water Fact Sheet 2001-9, available on the Web, accessed April 24, 2002, at http://wqm.igsb.uiowa.edu

Kalkhoff, S.J., Kolpin, D.W., Thurman, E.M., Ferrer, I., and Barcelo, D., 1998, Degradation of chloroacetanilide herbicides - the prevalence of sulfonic and oxanilic acid metabolites in Iowa groundwaters and surface waters: Environmental Science \& Technology, v. 32, p. 1738-1740.

Kalkhoff, S.J., Lee, K.E., Porter, S.D., Terrio, P.J., and Thurman, E.M., 2003, Herbicides and herbicide degradation 
products in upper Midwest agricultural streams during August base-flow conditions: Journal of Environmental Quality, v. 32, p. 1025-1035.

Kolpin, D.W., Kalkhoff, S.J., Goolsby, D.A., Sneck-Fahrer, D.A., and Thurman, E.M., 1997, Occurrence of selected herbicides and herbicide degradation products in Iowa's ground water, 1995: Ground Water, v. 35, no. 5, p. 679688.

Kolpin, D.W., Nations, B.K., Goolsby, D.A., and Thurman, E.M., 1996, Acetochlor in the hydrogeologic system in the Midwestern United States, 1994: Environmental Science \& Technology, v. 30, p. 1459-1464.

Kolpin, D.W., Schnoebelen, D.J., and Thurman, E.M., 2004, Degradates provide insight to spatial and temporal trends of herbicides in ground water: Ground Water, v. 42, no. 4., p. 601-608.

Kolpin, D.W., Thurman, E.M., and Linhart, S.M., 1998, The environmental occurrence of herbicides - the importance of degradates in ground water: Archives of Environmental Contamination and Toxicology, v. 35, p. 385-390.

Kolpin, D.W., Thurman, E.M., and Linhart, S.M., 2000, Finding minimal herbicide concentrations in ground water? Try looking for degradates: Science of the Total Environment, v. 248, p. 115-122.

Kolpin, D.W., Thurman, E.M., and Linhart, S.M., 2001, Occurrence of cyanazine compounds in groundwater-degradates more prevalent than the parent compound: Environmental Science \& Technology, v. 35, no. 6, p. 1217-1222.

Lee, E.A., and Strahan, A.P., 2003, Methods of analysis by the U.S. Geological Survey Organic Geochemistry Research Group - determination of acetamide herbicides and their degradation products in water using online solid-phase extraction and high-performance liquid chromatography/ mass spectrometry: U.S. Geological Survey Open-File Report 03-173, $17 \mathrm{p}$.

Lee, E.A., Strahan, A.P., and Thurman, E.M., 2002, Methods of analysis by the U.S. Geological Survey Organic Geochemistry Research Group-determination of triazine and phenylurea herbicides and their degradation products in water using solid-phase extraction and liquid chromatography/mass spectrometry: U.S. Geological Survey Open-File Report 02-436, 19 p.

Lin, C.H., Lerch, R.N., Thurman, E.M., Garrett, H.E., and George, M.F., 2002, Determination of isoxaflutole (Balance) and its metabolites in water using solid-phase extraction followed by high-performance liquid chromatography with ultraviolet or mass spectrometry: Journal of Agriculture and Food Chemistry, v. 50, p. 5816-5824.

Lindley, C.E., Stewart, J.T., and Sandstrom, M.W., 1996, Determination of low concentrations of acetochlor in water by automated solid-phase extraction and gas chromatography with mass selective detection: Journal of AOAC International, v. 79, no. 4, p. 962-966.

Luscombe, B.M., Pallett, K.E., Loubiere, P., Millet, J.C., Melgarejo, J., and Vrabel, T.E., 1995, A novel herbicide for broadleaf and grass weed control in maize and sugarcane, in Proceedings of the 1995 Brighton Crop Protection Conference: Weeds, v. 2, p. 35-42.

Madsen, J.E., Sandstrom, M.W., and Zaugg, S.D., 2003, Methods of analysis by the U.S. Geological Survey National Water Quality Laboratory - a method supplement for the determination of fipronil and degradates in water by gas chromatography/mass spectrometry: U.S. Geological Survey Open-File Report 02-462, 11 p.

Meyer, M.T., Thurman, E.M., and Goolsby, D.A., 1996, Cyanazine, atrazine, and their metabolites as geochemical indicators of contaminant transport in the Mississippi River, in Meyer, M.T., and Thurman, E.M., eds., Herbicide metabolites in surface water and groundwater: American Chemical Society Symposium Series 630, chap. 21, p. 288-303.

Nalley, G.M., Gorman, J.G., Goodrich, R.D., Miller, V.E., Turco, M.J., and Linhart, S.M., 2001, Water resources data, Iowa, water year 2001: U.S. Geological Survey Water-Data Report IA-01-1, 383 p.

Pallet, K.E., Cramp, S.M., Little, J.P., Veerasekaran, P., Crudace, A.J., and Slater, A.E., 2001, Isoxaflutole-the background to its discovery and the basis of its herbicidal properties: Pesticide Management Science, v. 57, p. 133.

Schnoebelen, D.J., Kalkhoff, S.J., Becher, K.D., and Thurman, E.M., 2003, Water-quality assessment of the eastern Iowa streams, 1996-98: U.S. Geological Survey WaterResources Investigations Report 03-4075, 62 p.

Scribner, E.A., Battaglin, W.A., Goolsby, D.A., and Thurman, E.M., 2000a, Changes in herbicide concentrations in Midwestern streams in relation to changes in use: Science of the Total Environment, v. 248, p. 255-263.

Scribner, E.A., Dietze, J.E., and Thurman, E.M., 2004, Acetamide herbicides and their degradation products in ground water and surface water of the United States, 1993-2003: U.S. Geological Survey Data Series 88, 252 p.

Scribner, E.A, Goolsby, D.A., Thurman, E.M., and Battaglin, W.A., 1998, A reconnaissance for selected herbicides, metabolites, and nutrients in streams of nine Midwestern States, 1994-95: U.S. Geological Survey Open-File Report 98-181, 44 p.

Scribner, E.A., Thurman, E.M., Goolsby, D.A., Meyer, M.T., Battaglin, W.A., and Kolpin, D.W., 2005, Summary of significant results from studies of triazine herbicides and their degradation products in surface water, ground water, and precipitation in the Midwestern United States during the 
1990s: U.S. Geological Survey Scientific Investigations Report 2005-5094, $27 \mathrm{p}$.

Scribner, E.A., Thurman, E.M., Goolsby, D.A., Meyer, M.T., Mills, M.S., and Pomes, M.L., 1993, Reconnaissance data for selected herbicides, two atrazine metabolites, and nitrate in surface water of the Midwestern United States, 1989-90: U.S. Geological Survey Open-File Report 93-457, 77 p.

Scribner, E.A., Thurman, E.M., and Zimmerman, L.R., 2000b, Analysis of selected herbicide metabolites in surface and ground water of the United States: Science of the Total Environment, v. 248, p. 157-168.

Shelton, L.R., 1994, Field guide for collection and processing stream-water samples for the National Water-Quality Assessment Program: U.S. Geological Survey Open-File Report 94-455, 42 p.

Thurman, E.M., and Fallon, J.D., 1996, The deethylatrazine/ atrazine ratio as an indicator of the onset of the spring flush of herbicides into surface water of the Midwestern United States: International Journal of Environmental Analytical Chemistry, v. 65, p. 203-214.

Thurman, E.M., Goolsby, D.A., Meyer, M.T., and Kolpin, D.W., 1991, Herbicides in surface waters of the Midwestern United States - the effect of spring flush: Environmental Science \& Technology, v. 25, p. 1794-1796.

Thurman, E.M., Goolsby, D.A., Meyer, M.T., Mills, M.S., Pomes, M.L., and Kolpin, D.W., 1992, A reconnaissance study of herbicides and their metabolites in surface water of the Midwestern United States using immunoassay and gas chromatography/mass spectrometry: Environmental Science \& Technology, v. 26, p. 2440-2447.
Thurman, E.M., Meyer, M.T., Mills, M.L., Zimmerman, L.R., Perry, C.A., and Goolsby, D.A.,1994, Formation and transport of deethylatrazine and deisopropylatrazine in surface water: Environmental Science \& Technology, v. 28, p. 2267-2277.

U.S. Department of Agriculture, 2004, National Agricultural Statistics Service (NASS) agriculture chemical use database: Information available on the Web, accessed February 6, 2006, at http://www.pestmanagement.info/nass

Viviani, F., Little, J.P., and Pallett, K.E., 1998, The mode of action of isoxaflutole II. Characterization of the inhibition of carrot 4-hydroxyphenylpyruvate dioxygenase by diketonitrile derivative of isoxaflutole: Pesticide Biochemistry and Physiology, v. 62, no. 2, p. 125-134.

Webb, W.E., Radatke, D.B., and Iwatsubo, R.T., 1999, Surface-water sampling collection methods at flowing-water and still-water sites: U.S. Geological Survey Techniques in Water-Resources Investigations, book 9, chap. A4, section 4.1, p. 23-59.

Wilde, F.D., Radtke, D.B., Gibs, Jacob, and Iwatsubo, R.T., 1998, National field manual for the collection of water-quality data - preparations for water sampling: U.S. Geological Survey Techniques of Water-Resources Investigations, book 9, chap. A1-A5 [variously paged].

Zaugg, S.D., Sandstrom, M.W., Smith, S.G., and Fehlberg, K.M., 1995, Methods of analysis by the U.S. Geological Survey National Water Quality Laboratory-determination of pesticides in water by $\mathrm{C}-18$ solid-phase extraction and capillary-column gas chromatography/mass spectrometry with selected-ion monitoring: U.S. Geological Survey Open-File Report 95-181, 60 p. 


\section{Supplemental Information}


Table 8. Concentrations of acetamide herbicides and their degradation products analyzed by the U.S. Geological Survey Organic Geochemistry Research Laboratory, Lawrence, Kansas, for water samples collected from 10 rivers in lowa, 2004.

[ESA, ethanesulfonic acid; OXA, oxanilic acid; SAA, sulfynil acetic acid; <, less than; --, no data]

\begin{tabular}{|c|c|c|c|c|c|c|c|c|c|}
\hline \multirow[b]{2}{*}{$\begin{array}{c}\text { Map } \\
\text { number } \\
\text { (fig. 4) }\end{array}$} & \multirow{2}{*}{$\begin{array}{l}\text { U.S. Geologi- } \\
\text { cal Survey } \\
\text { site } \\
\text { identifica- } \\
\text { tion number }\end{array}$} & \multirow[b]{2}{*}{ Site name } & \multirow[b]{2}{*}{$\begin{array}{c}\text { Date of } \\
\text { collection } \\
\text { (month/day/ } \\
\text { year) }\end{array}$} & \multirow{2}{*}{$\begin{array}{l}\text { Collec- } \\
\text { tion } \\
\text { time } \\
\text { (24- } \\
\text { hour) }\end{array}$} & \multicolumn{5}{|c|}{ Concentrations, in micrograms per liter } \\
\hline & & & & & $\begin{array}{c}\text { Aceto- } \\
\text { chlor }\end{array}$ & $\begin{array}{l}\text { Aceto- } \\
\text { chlor } \\
\text { de- } \\
\text { schloro }\end{array}$ & $\begin{array}{l}\text { Aceto- } \\
\text { chlor } \\
\text { ESA }\end{array}$ & $\begin{array}{c}\text { Aceto- } \\
\text { chlor } \\
\text { hydroxy }\end{array}$ & $\begin{array}{c}\text { Aceto- } \\
\text { chlor } \\
\text { OXA }\end{array}$ \\
\hline \multirow[t]{6}{*}{1} & 05412500 & Turkey River at Garber & $03 / 15 / 04$ & 1100 & 0.04 & -- & 0.16 & -- & 0.23 \\
\hline & & & $04 / 20 / 04$ & 0950 & $<.02$ & -- & .22 & -- & .06 \\
\hline & & & 05/19/04 & 1200 & 2.2 & 0.07 & 1.2 & -- & .81 \\
\hline & & & 05/24/04 & 1115 & .13 & .02 & 2.9 & -- & .69 \\
\hline & & & 06/10/04 & 1000 & .34 & .02 & .85 & -- & .46 \\
\hline & & & 07/21/04 & 1130 & $<.02$ & $<.02$ & .75 & $<0.02$ & .10 \\
\hline \multirow[t]{7}{*}{2} & 5418600 & Maquoketa River near Spragueville & 03/15/04 & 1700 & $<.02$ & -- & .16 & -- & .12 \\
\hline & & & 03/29/04 & 1500 & $<.02$ & -- & .50 & -- & .16 \\
\hline & & & $04 / 20 / 04$ & 1510 & .02 & -- & .26 & -- & .04 \\
\hline & & & 05/19/04 & 0800 & .58 & $<.02$ & .32 & -- & .44 \\
\hline & & & $05 / 25 / 04$ & 1015 & 6.1 & .12 & 1.3 & -- & 2.2 \\
\hline & & & 06/10/04 & 1300 & .05 & .03 & .74 & -- & .39 \\
\hline & & & $07 / 21 / 04$ & 0720 & $<.02$ & $<.02$ & .45 & $<.02$ & .13 \\
\hline \multirow[t]{6}{*}{3} & 05422000 & Wapsipinicon River near DeWitt & 03/17/04 & 0830 & .03 & -- & .31 & -- & .28 \\
\hline & & & $04 / 15 / 04$ & 0830 & $<.02$ & -- & .60 & -- & .16 \\
\hline & & & 05/18/04 & 1200 & 2.6 & .08 & .94 & -- & 1.0 \\
\hline & & & $05 / 25 / 04$ & 1430 & 3.1 & .09 & 1.8 & -- & 2.3 \\
\hline & & & 06/16/04 & 1230 & .16 & .04 & 1.7 & -- & .82 \\
\hline & & & 07/20/04 & 1200 & .02 & $<.02$ & 1.7 & .04 & .38 \\
\hline \multirow[t]{5}{*}{4} & 05474000 & Skunk River at Augusta & 03/17/04 & 1430 & .03 & -- & .15 & -- & .18 \\
\hline & & & $04 / 15 / 04$ & 1345 & $<.02$ & -- & .18 & -- & .08 \\
\hline & & & 05/18/04 & 0730 & .59 & .05 & .37 & -- & .43 \\
\hline & & & 06/16/04 & 0900 & .20 & .03 & 1.6 & -- & 2.0 \\
\hline & & & 07/20/04 & 0800 & $<.02$ & $<.02$ & .52 & $<.02$ & .19 \\
\hline \multirow[t]{5}{*}{5} & 05490500 & Des Moines River at Keosauqua & 03/18/04 & 1230 & .05 & -- & .14 & -- & .24 \\
\hline & & & $04 / 22 / 04$ & 0910 & .02 & -- & .30 & -- & .26 \\
\hline & & & 05/17/04 & 1400 & .42 & .02 & .27 & -- & .22 \\
\hline & & & 06/14/04 & 1400 & .64 & .04 & .87 & -- & 1.3 \\
\hline & & & 07/19/04 & 1600 & .11 & .02 & .87 & .10 & .56 \\
\hline 6 & 06485500 & Big Sioux River at Akron & 03/09/04 & 1200 & .33 & -- & .80 & -- & 1.5 \\
\hline
\end{tabular}


Table 8. Concentrations of acetamide herbicides and their degradation products analyzed by the U.S. Geological Survey Organic Geochemistry Research Laboratory, Lawrence, Kansas, for water samples collected from 10 rivers in lowa, 2004.-Continued

[ESA, ethanesulfonic acid; OXA, oxanilic acid; SAA, sulfynil acetic acid; <, less than; --, no data]

\begin{tabular}{|c|c|c|c|c|c|c|c|c|c|}
\hline \multirow[b]{2}{*}{$\begin{array}{c}\text { Map } \\
\text { number } \\
\text { (fig. 4) }\end{array}$} & \multirow{2}{*}{$\begin{array}{l}\text { U.S. Geologi- } \\
\text { cal Survey } \\
\text { site } \\
\text { identifica- } \\
\text { tion number }\end{array}$} & \multirow[b]{2}{*}{ Site name } & \multirow[b]{2}{*}{$\begin{array}{c}\text { Date of } \\
\text { collection } \\
\text { (month/day/ } \\
\text { year) }\end{array}$} & \multirow{2}{*}{$\begin{array}{l}\text { Collec- } \\
\text { tion } \\
\text { time } \\
\text { (24- } \\
\text { hour) }\end{array}$} & \multicolumn{5}{|c|}{ Concentrations, in micrograms per liter } \\
\hline & & & & & $\begin{array}{l}\text { Aceto- } \\
\text { chlor }\end{array}$ & $\begin{array}{l}\text { Aceto- } \\
\text { chlor } \\
\text { de- } \\
\text { schloro }\end{array}$ & $\begin{array}{l}\text { Aceto- } \\
\text { chlor } \\
\text { ESA }\end{array}$ & $\begin{array}{l}\text { Aceto- } \\
\text { chlor } \\
\text { hydroxy }\end{array}$ & $\begin{array}{c}\text { Aceto- } \\
\text { chlor } \\
\text { OXA }\end{array}$ \\
\hline \multirow[t]{5}{*}{6} & 06485500 & Big Sioux River at Akron & 04/13/04 & 0930 & $<0.02$ & -- & 0.11 & -- & 0.15 \\
\hline & & & $05 / 12 / 04$ & 1030 & .04 & $<.02$ & .07 & -- & .08 \\
\hline & & & $05 / 26 / 04$ & 1300 & .64 & .02 & .72 & -- & .87 \\
\hline & & & 06/02/04 & 1215 & 1.3 & .05 & .83 & -- & 1.3 \\
\hline & & & $07 / 14 / 04$ & 1030 & $<.02$ & $<.02$ & .34 & 0.04 & .30 \\
\hline \multirow[t]{7}{*}{7} & 06607500 & Little Sioux River near Turin & 03/10/04 & 0830 & .03 & -- & .25 & -- & .56 \\
\hline & & & 04/13/04 & 1400 & $<.02$ & -- & .11 & -- & .09 \\
\hline & & & 05/11/04 & 1020 & .43 & $<.02$ & .15 & -- & .19 \\
\hline & & & $05 / 24 / 04$ & 1100 & 1.4 & .03 & .33 & -- & .54 \\
\hline & & & 06/08/04 & 0850 & .08 & .02 & .31 & -- & .26 \\
\hline & & & 06/17/04 & 1230 & .08 & $<.02$ & .14 & -- & .20 \\
\hline & & & 07/13/04 & 1000 & $<.02$ & $<.02$ & .32 & $<.02$ & .22 \\
\hline \multirow[t]{6}{*}{8} & 06609500 & Boyer River at Logan & $04 / 14 / 04$ & 0730 & $<.02$ & -- & .07 & -- & .06 \\
\hline & & & 05/11/04 & 1300 & .09 & $<.02$ & .07 & -- & .05 \\
\hline & & & $05 / 23 / 04$ & 1015 & 8.6 & .11 & .84 & -- & 1.7 \\
\hline & & & 06/08/04 & 1130 & .04 & $<.02$ & .14 & -- & .09 \\
\hline & & & $06 / 17 / 04$ & 1000 & .27 & .02 & .44 & -- & .80 \\
\hline & & & 07/13/04 & 1230 & $<.02$ & $<.02$ & .15 & $<.02$ & .06 \\
\hline \multirow[t]{7}{*}{9} & 06810000 & Nishnabotna River above Hamburg & 03/11/04 & 1030 & $<.02$ & -- & .07 & -- & .09 \\
\hline & & & 03/29/04 & 1230 & .02 & -- & .09 & -- & .10 \\
\hline & & & $04 / 12 / 04$ & 1300 & $<.02$ & -- & .05 & -- & .03 \\
\hline & & & 05/10/04 & 1230 & 3.1 & .03 & .20 & -- & .32 \\
\hline & & & $05 / 25 / 04$ & 1045 & .75 & .02 & .57 & -- & .85 \\
\hline & & & 06/07/04 & 1245 & .05 & $<.02$ & .13 & -- & .08 \\
\hline & & & $07 / 12 / 04$ & 1230 & $<.02$ & $<.02$ & .10 & $<.02$ & .09 \\
\hline \multirow[t]{5}{*}{10} & 06904010 & Chariton River near Moulton & 03/18/04 & 0900 & $<.02$ & -- & .14 & -- & .47 \\
\hline & & & $04 / 22 / 04$ & 1320 & $<.02$ & -- & .20 & -- & .35 \\
\hline & & & 05/17/04 & 1100 & .05 & .02 & .21 & -- & .35 \\
\hline & & & 06/14/04 & 1050 & .15 & .03 & 1.3 & -- & 2.1 \\
\hline & & & 07/19/04 & 1230 & .05 & .02 & .42 & .09 & .69 \\
\hline
\end{tabular}


Table 8. Concentrations of acetamide herbicides and their degradation products analyzed by the U.S. Geological Survey Organic Geochemistry Research Laboratory, Lawrence, Kansas, for water samples collected from 10 rivers in lowa, 2004.-Continued

[ESA, ethanesulfonic acid; OXA, oxanilic acid; SAA, sulfynil acetic acid; <, less than; --, no data]

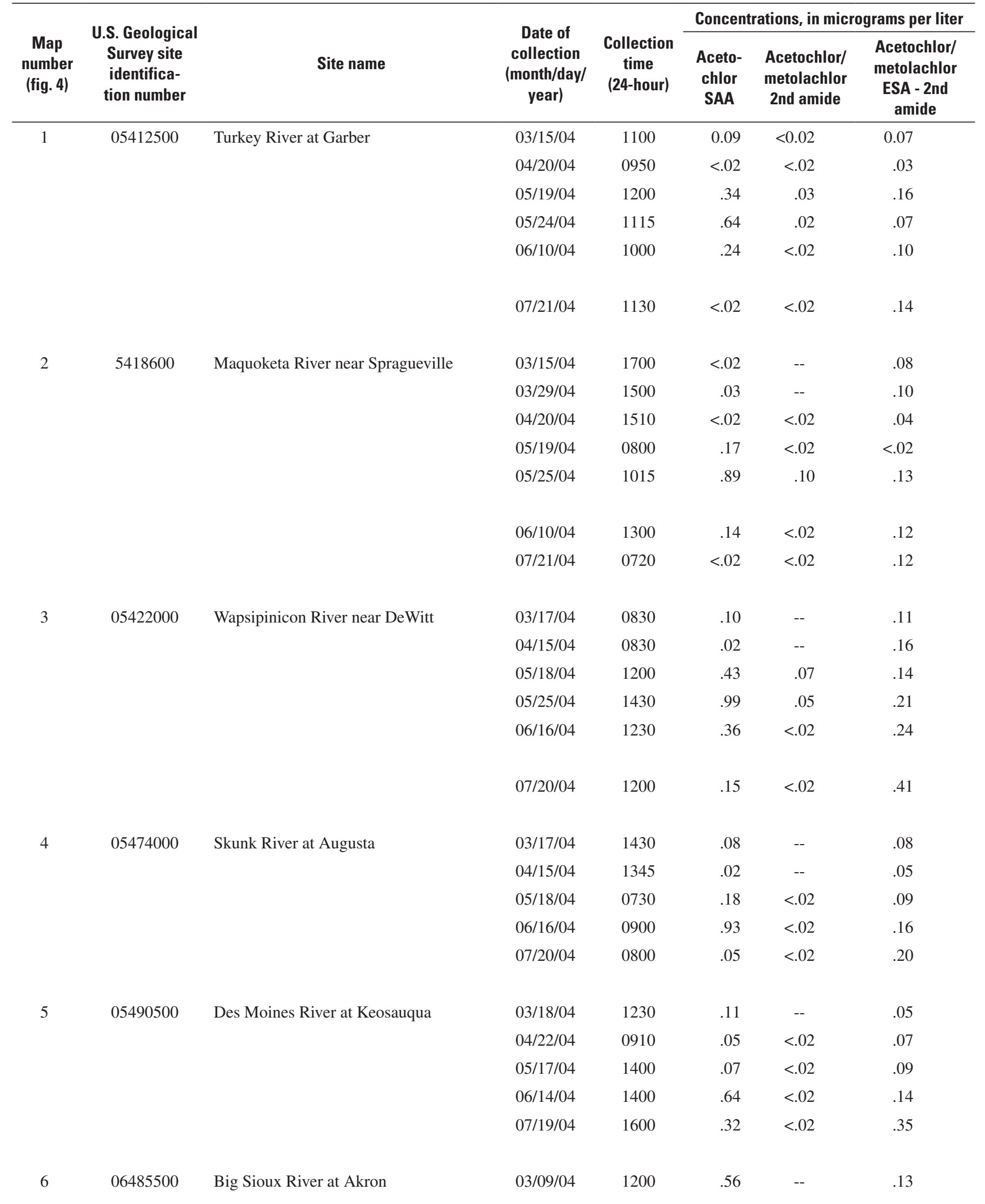


Table 8. Concentrations of acetamide herbicides and their degradation products analyzed by the U.S. Geological Survey Organic Geochemistry Research Laboratory, Lawrence, Kansas, for water samples collected from 10 rivers in lowa, 2004.-Continued

[ESA, ethanesulfonic acid; OXA, oxanilic acid; SAA, sulfynil acetic acid; <, less than; --, no data]

\begin{tabular}{|c|c|c|c|c|c|c|c|}
\hline \multirow[b]{2}{*}{$\begin{array}{l}\text { Map } \\
\text { number } \\
\text { (fig. 4) }\end{array}$} & \multirow[b]{2}{*}{$\begin{array}{l}\text { U.S. Geological } \\
\text { Survey site } \\
\text { identifica- } \\
\text { tion number }\end{array}$} & \multirow[b]{2}{*}{ Site name } & \multirow[b]{2}{*}{$\begin{array}{c}\text { Date of } \\
\text { collection } \\
\text { (month/day/ } \\
\text { year) }\end{array}$} & \multirow[b]{2}{*}{$\begin{array}{l}\text { Collection } \\
\text { time } \\
\text { (24-hour) }\end{array}$} & \multicolumn{3}{|c|}{ Concentrations, in micrograms per liter } \\
\hline & & & & & $\begin{array}{l}\text { Aceto- } \\
\text { chlor } \\
\text { SAA }\end{array}$ & $\begin{array}{l}\text { Acetochlor/ } \\
\text { metolachlor } \\
\text { 2nd amide }\end{array}$ & $\begin{array}{l}\text { Acetochlor/ } \\
\text { metolachlor } \\
\text { ESA - 2nd } \\
\text { amide }\end{array}$ \\
\hline \multirow[t]{4}{*}{6} & 06485500 & Big Sioux River at Akron & 04/13/04 & 0930 & 0.04 & -- & 0.03 \\
\hline & & & $05 / 12 / 04$ & 1030 & $<.02$ & $<0.02$ & .03 \\
\hline & & & 06/02/04 & 1215 & .50 & .03 & .07 \\
\hline & & & 07/14/04 & 1030 & .12 & $<.02$ & .09 \\
\hline \multirow[t]{4}{*}{7} & 06607500 & Little Sioux River near Turin & 03/10/04 & 0830 & .19 & -- & .08 \\
\hline & & & 06/08/04 & 0850 & .10 & $<.02$ & .07 \\
\hline & & & $06 / 17 / 04$ & 1230 & .08 & $<.02$ & .04 \\
\hline & & & 07/13/04 & 1000 & .10 & $<.02$ & .09 \\
\hline \multirow[t]{3}{*}{8} & 06609500 & Boyer River at Logan & $04 / 14 / 04$ & 0730 & $<.02$ & -- & .05 \\
\hline & & & 05/11/04 & 1300 & $<.02$ & $<.02$ & .02 \\
\hline & & & $05 / 23 / 04$ & 1015 & .70 & .07 & .07 \\
\hline \multirow{6}{*}{9} & & & $03 / 29 / 04$ & 1230 & .04 & -- & .05 \\
\hline & & & $04 / 12 / 04$ & 1300 & $<.02$ & -- & $<.02$ \\
\hline & & & 05/10/04 & 1230 & .12 & .08 & .03 \\
\hline & & & $05 / 25 / 04$ & 1045 & .26 & $<.02$ & .03 \\
\hline & & & 06/07/04 & 1245 & .06 & $<.02$ & .05 \\
\hline & & & $07 / 12 / 04$ & 1230 & $<.02$ & $<.02$ & .04 \\
\hline \multirow[t]{5}{*}{10} & 06904010 & Chariton River near Moulton & $03 / 18 / 04$ & 0900 & .11 & -- & .04 \\
\hline & & & $04 / 22 / 04$ & 1320 & .07 & $<.02$ & .03 \\
\hline & & & 05/17/04 & 1100 & .07 & $<.02$ & .03 \\
\hline & & & 06/14/04 & 1050 & .81 & $<.02$ & .12 \\
\hline & & & 07/19/04 & 1230 & .23 & $<.02$ & .13 \\
\hline
\end{tabular}


Table 8. Concentrations of acetamide herbicides and their degradation products analyzed by the U.S. Geological Survey Organic Geochemistry Research Laboratory, Lawrence, Kansas, for water samples collected from 10 rivers in lowa, 2004.-Continued

[ESA, ethanesulfonic acid; OXA, oxanilic acid; SAA, sulfynil acetic acid; <, less than; --, no data]

\begin{tabular}{|c|c|c|c|c|c|c|c|c|}
\hline \multirow{2}{*}{$\begin{array}{c}\text { Map } \\
\text { number } \\
\text { (fig. 4) }\end{array}$} & \multirow{2}{*}{$\begin{array}{l}\text { U.S. Geological } \\
\text { Survey site } \\
\text { identifica- } \\
\text { tion number }\end{array}$} & \multirow[b]{2}{*}{ Site name } & \multirow{2}{*}{$\begin{array}{c}\text { Date of } \\
\text { collection } \\
\text { (month/day/ } \\
\text { year) }\end{array}$} & \multirow{2}{*}{$\begin{array}{l}\text { Collection } \\
\text { time } \\
\text { (24-hour) }\end{array}$} & \multicolumn{4}{|c|}{ Concentrations, in micrograms per liter } \\
\hline & & & & & Alachlor & $\begin{array}{l}\text { Alachlor } \\
\text { deschloro }\end{array}$ & $\begin{array}{c}\text { Alachlor } \\
\text { ESA }\end{array}$ & $\begin{array}{l}\text { Alachlor } \\
\text { hydroxy }\end{array}$ \\
\hline \multirow[t]{6}{*}{1} & 5412500 & Turkey River at Garber & 03/15/04 & 1100 & $<0.02$ & -- & 0.25 & -- \\
\hline & & & $04 / 20 / 04$ & 0950 & $<.02$ & $<0.02$ & .46 & -- \\
\hline & & & 05/19/04 & 1200 & $<.02$ & $<.02$ & .44 & -- \\
\hline & & & $05 / 24 / 04$ & 1115 & $<.02$ & $<.02$ & .30 & -- \\
\hline & & & $06 / 10 / 04$ & 1000 & $<.02$ & $<.02$ & .28 & -- \\
\hline & & & $07 / 21 / 04$ & 1130 & $<.02$ & $<.02$ & .36 & $<0.02$ \\
\hline \multirow[t]{7}{*}{2} & 5418600 & Maquoketa River near Spragueville & 03/15/04 & 1700 & $<.02$ & -- & .29 & -- \\
\hline & & & $03 / 29 / 04$ & 1500 & $<.02$ & -- & .29 & -- \\
\hline & & & $04 / 20 / 04$ & 1510 & $<.02$ & $<.02$ & .56 & -- \\
\hline & & & 05/19/04 & 0800 & $<.02$ & $<.02$ & .39 & -- \\
\hline & & & $05 / 25 / 04$ & 1015 & $<.02$ & $<.02$ & .13 & -- \\
\hline & & & 06/10/04 & 1300 & $<.02$ & $<.02$ & .43 & -- \\
\hline & & & $07 / 21 / 04$ & 0720 & $<.02$ & $<.02$ & .48 & $<.02$ \\
\hline \multirow[t]{6}{*}{3} & 5422000 & Wapsipinicon River near DeWitt & 03/17/04 & 0830 & $<.02$ & -- & .40 & -- \\
\hline & & & $04 / 15 / 04$ & 0830 & $<.02$ & -- & .69 & -- \\
\hline & & & 05/18/04 & 1200 & $<.02$ & $<.02$ & .39 & -- \\
\hline & & & $05 / 25 / 04$ & 1430 & .09 & $<.02$ & .37 & -- \\
\hline & & & 06/16/04 & 1230 & $<.02$ & $<.02$ & .43 & -- \\
\hline & & & 07/20/04 & 1200 & $<.02$ & $<.02$ & .51 & $<.02$ \\
\hline \multirow[t]{5}{*}{4} & 5474000 & Skunk River at Augusta & 03/17/04 & 1430 & $<.02$ & -- & .12 & -- \\
\hline & & & $04 / 15 / 04$ & 1345 & $<.02$ & -- & .16 & -- \\
\hline & & & 05/18/04 & 0730 & $<.02$ & $<.02$ & .11 & -- \\
\hline & & & 06/16/04 & 0900 & $<.02$ & $<.02$ & .06 & -- \\
\hline & & & 07/20/04 & 0800 & $<.02$ & $<.02$ & .07 & $<.02$ \\
\hline \multirow[t]{5}{*}{5} & 5490500 & Des Moines River at Keosauqua & 03/18/04 & 1230 & $<.02$ & -- & .08 & -- \\
\hline & & & $04 / 22 / 04$ & 0910 & $<.02$ & $<.02$ & .07 & -- \\
\hline & & & 05/17/04 & 1400 & $<.02$ & $<.02$ & .05 & -- \\
\hline & & & 06/14/04 & 1400 & $<.02$ & $<.02$ & .04 & -- \\
\hline & & & 07/19/04 & 1600 & $<.02$ & $<.02$ & .04 & $<.02$ \\
\hline \multirow[t]{2}{*}{6} & 6485500 & Big Sioux River at Akron & 03/09/04 & 1200 & $<.02$ & -- & .08 & -- \\
\hline & & & 04/13/04 & 0930 & $<.02$ & -- & .08 & -- \\
\hline
\end{tabular}


Table 8. Concentrations of acetamide herbicides and their degradation products analyzed by the U.S. Geological Survey Organic Geochemistry Research Laboratory, Lawrence, Kansas, for water samples collected from 10 rivers in lowa, 2004.-Continued

[ESA, ethanesulfonic acid; OXA, oxanilic acid; SAA, sulfynil acetic acid; <, less than; --, no data]

\begin{tabular}{|c|c|c|c|c|c|c|c|c|}
\hline \multirow{2}{*}{$\begin{array}{c}\text { Map } \\
\text { number } \\
\text { (fig. 4) }\end{array}$} & \multirow{2}{*}{$\begin{array}{l}\text { U.S. Geological } \\
\text { Survey site } \\
\text { identifica- } \\
\text { tion number }\end{array}$} & \multirow[b]{2}{*}{ Site name } & \multirow{2}{*}{$\begin{array}{c}\text { Date of } \\
\text { collection } \\
\text { (month/day/ } \\
\text { year) }\end{array}$} & \multirow{2}{*}{$\begin{array}{c}\text { Collection } \\
\text { time } \\
\text { (24-hour) }\end{array}$} & \multicolumn{4}{|c|}{ Concentrations, in micrograms per liter } \\
\hline & & & & & Alachlor & $\begin{array}{l}\text { Alachlor } \\
\text { deschloro }\end{array}$ & $\begin{array}{c}\text { Alachlor } \\
\text { ESA }\end{array}$ & $\begin{array}{l}\text { Alachlor } \\
\text { hydroxy }\end{array}$ \\
\hline \multirow[t]{4}{*}{6} & 6485500 & Big Sioux River at Akron & $05 / 12 / 04$ & 1030 & $<0.02$ & $<0.02$ & 0.05 & -- \\
\hline & & & $05 / 26 / 04$ & 1300 & $<.02$ & $<.02$ & .06 & -- \\
\hline & & & 06/02/04 & 1215 & .03 & $<.02$ & .04 & -- \\
\hline & & & 07/14/04 & 1030 & $<.02$ & $<.02$ & .05 & $<0.02$ \\
\hline \multirow[t]{7}{*}{7} & 6607500 & Little Sioux River near Turin & 03/10/04 & 0830 & $<.02$ & -- & .08 & -- \\
\hline & & & 04/13/04 & 1400 & $<.02$ & -- & .09 & -- \\
\hline & & & $05 / 11 / 04$ & 1020 & $<.02$ & $<.02$ & .06 & -- \\
\hline & & & $05 / 24 / 04$ & 1100 & $<.02$ & $<.02$ & $<.02$ & -- \\
\hline & & & 06/08/04 & 0850 & $<.02$ & $<.02$ & .05 & -- \\
\hline & & & 06/17/04 & 1230 & $<.02$ & $<.02$ & $<.02$ & -- \\
\hline & & & $07 / 13 / 04$ & 1000 & $<.02$ & $<.02$ & .05 & $<.02$ \\
\hline \multirow[t]{6}{*}{8} & 6609500 & Boyer River at Logan & $04 / 14 / 04$ & 0730 & $<.02$ & -- & .07 & -- \\
\hline & & & $05 / 11 / 04$ & 1300 & $<.02$ & $<.02$ & .06 & -- \\
\hline & & & $05 / 23 / 04$ & 1015 & $<.02$ & $<.02$ & .02 & -- \\
\hline & & & 06/08/04 & 1130 & $<.02$ & $<.02$ & .03 & -- \\
\hline & & & 06/17/04 & 1000 & $<.02$ & $<.02$ & $<.02$ & -- \\
\hline & & & 07/13/04 & 1230 & $<.02$ & $<.02$ & .02 & $<.02$ \\
\hline \multirow[t]{7}{*}{9} & 6810000 & Nishnabotna River above Hamburg & 03/11/04 & 1030 & $<.02$ & -- & .08 & -- \\
\hline & & & $03 / 29 / 04$ & 1230 & $<.02$ & -- & .02 & -- \\
\hline & & & $04 / 12 / 04$ & 1300 & $<.02$ & -- & .05 & -- \\
\hline & & & $05 / 10 / 04$ & 1230 & .15 & $<.02$ & .04 & -- \\
\hline & & & $05 / 25 / 04$ & 1045 & $<.02$ & $<.02$ & .04 & -- \\
\hline & & & 06/07/04 & 1245 & $<.02$ & $<.02$ & .03 & -- \\
\hline & & & $07 / 12 / 04$ & 1230 & $<.02$ & $<.02$ & .02 & $<.02$ \\
\hline \multirow[t]{5}{*}{10} & 6904010 & Chariton River near Moulton & $03 / 18 / 04$ & 0900 & $<.02$ & -- & .07 & -- \\
\hline & & & $04 / 22 / 04$ & 1320 & $<.02$ & $<.02$ & .07 & -- \\
\hline & & & $05 / 17 / 04$ & 1100 & $<.02$ & $<.02$ & .05 & -- \\
\hline & & & 06/14/04 & 1050 & $<.02$ & $<.02$ & .03 & -- \\
\hline & & & 07/19/04 & 1230 & $<.02$ & $<.02$ & $<.02$ & $<.02$ \\
\hline
\end{tabular}


Table 8. Concentrations of acetamide herbicides and their degradation products analyzed by the U.S. Geological Survey Organic Geochemistry Research Laboratory, Lawrence, Kansas, for water samples collected from 10 rivers in lowa, 2004.-Continued

[ESA, ethanesulfonic acid; OXA, oxanilic acid; SAA, sulfynil acetic acid; <, less than; --, no data]

\begin{tabular}{|c|c|c|c|c|c|c|c|c|c|}
\hline \multirow[b]{2}{*}{$\begin{array}{c}\text { Map } \\
\text { number } \\
\text { (fig. 4) }\end{array}$} & \multirow[b]{2}{*}{$\begin{array}{l}\text { U.S. Geo- } \\
\text { logical } \\
\text { Survey site } \\
\text { identifica- } \\
\text { tion number }\end{array}$} & \multirow[b]{2}{*}{ Site name } & \multirow[b]{2}{*}{$\begin{array}{c}\text { Date of } \\
\text { collection } \\
\text { (month/ } \\
\text { day/ } \\
\text { year) }\end{array}$} & \multirow[b]{2}{*}{$\begin{array}{l}\text { Collec- } \\
\text { tion time } \\
\text { (24-hour) }\end{array}$} & \multicolumn{5}{|c|}{ Concentrations, in micrograms per liter } \\
\hline & & & & & $\begin{array}{l}\text { Ala- } \\
\text { chlor } \\
\text { OXA }\end{array}$ & $\begin{array}{l}\text { Ala- } \\
\text { chlor } \\
\text { SAA }\end{array}$ & $\begin{array}{l}\text { Ala- } \\
\text { chlor } \\
\text { 2nd } \\
\text { amide }\end{array}$ & $\begin{array}{c}\text { Ala- } \\
\text { chlor } \\
\text { ESA - 2nd } \\
\text { amide }\end{array}$ & $\begin{array}{l}\text { Dimeth- } \\
\text { enamid }\end{array}$ \\
\hline \multirow[t]{6}{*}{1} & 5412500 & Turkey River at Garber & 03/15/04 & 1100 & 0.07 & $<0.02$ & $<0.02$ & -- & 0.03 \\
\hline & & & $04 / 20 / 04$ & 0950 & .03 & $<.02$ & $<.02$ & $<0.02$ & $<.02$ \\
\hline & & & 05/19/04 & 1200 & .04 & .06 & $<.02$ & $<.02$ & .71 \\
\hline & & & $05 / 24 / 04$ & 1115 & .03 & .58 & $<.02$ & .33 & .62 \\
\hline & & & $06 / 10 / 04$ & 1000 & .02 & $<.02$ & $<.02$ & $<.02$ & .42 \\
\hline & & & $07 / 21 / 04$ & 1130 & .02 & $<.02$ & $<.02$ & $<.02$ & $<.02$ \\
\hline \multirow[t]{7}{*}{2} & 5418600 & Maquoketa River near Spragueville & 03/15/04 & 1700 & .05 & $<.02$ & -- & $<.02$ & $<.02$ \\
\hline & & & $03 / 29 / 04$ & 1500 & .03 & $<.02$ & -- & $<.02$ & $<.02$ \\
\hline & & & $04 / 20 / 04$ & 1510 & .02 & $<.02$ & $<.02$ & $<.02$ & $<.02$ \\
\hline & & & $05 / 19 / 04$ & 0800 & .02 & $<.02$ & $<.02$ & $<.02$ & .02 \\
\hline & & & $05 / 25 / 04$ & 1015 & .02 & .63 & $<.02$ & .15 & 1.1 \\
\hline & & & $06 / 10 / 04$ & 1300 & .02 & $<.02$ & $<.02$ & $<.02$ & .03 \\
\hline & & & 07/21/04 & 0720 & .02 & $<.02$ & $<.02$ & $<.02$ & $<.02$ \\
\hline \multirow[t]{6}{*}{3} & 5422000 & Wapsipinicon River near DeWitt & 03/17/04 & 0830 & .10 & $<.02$ & -- & .03 & .03 \\
\hline & & & $04 / 15 / 04$ & 0830 & .06 & $<.02$ & $<.02$ & $<.02$ & $<.02$ \\
\hline & & & 05/18/04 & 1200 & .05 & .12 & $<.02$ & .16 & .98 \\
\hline & & & $05 / 25 / 04$ & 1430 & .09 & .58 & $<.02$ & .12 & .35 \\
\hline & & & $06 / 16 / 04$ & 1230 & .05 & $<.02$ & $<.02$ & .02 & .08 \\
\hline & & & 07/20/04 & 1200 & .04 & $<.02$ & $<.02$ & $<.02$ & $<.02$ \\
\hline \multirow[t]{5}{*}{4} & 5474000 & Skunk River at Augusta & 03/17/04 & 1430 & .06 & $<.02$ & $<.02$ & .02 & $<.02$ \\
\hline & & & $04 / 15 / 04$ & 1345 & .03 & $<.02$ & $<.02$ & $<.02$ & $<.02$ \\
\hline & & & 05/18/04 & 0730 & .02 & .02 & $<.02$ & .04 & .18 \\
\hline & & & $06 / 16 / 04$ & 0900 & .03 & $<.02$ & $<.02$ & $<.02$ & .08 \\
\hline & & & 07/20/04 & 0800 & .02 & $<.02$ & $<.02$ & $<.02$ & $<.02$ \\
\hline \multirow[t]{5}{*}{5} & 5490500 & Des Moines River at Keosauqua & 03/18/04 & 1230 & .05 & $<.02$ & -- & .02 & .03 \\
\hline & & & $04 / 22 / 04$ & 0910 & .03 & $<.02$ & $<.02$ & $<.02$ & $<.02$ \\
\hline & & & $05 / 17 / 04$ & 1400 & .02 & $<.02$ & $<.02$ & $<.02$ & .20 \\
\hline & & & $06 / 14 / 04$ & 1400 & .03 & $<.02$ & $<.02$ & $<.02$ & .24 \\
\hline & & & $07 / 19 / 04$ & 1600 & .02 & $<.02$ & $<.02$ & $<.02$ & $<.02$ \\
\hline 6 & 6485500 & Big Sioux River at Akron & 03/09/04 & 1200 & .07 & $<.02$ & -- & .05 & .04 \\
\hline
\end{tabular}


Table 8. Concentrations of acetamide herbicides and their degradation products analyzed by the U.S. Geological Survey Organic Geochemistry Research Laboratory, Lawrence, Kansas, for water samples collected from 10 rivers in lowa, 2004.-Continued

[ESA, ethanesulfonic acid; OXA, oxanilic acid; SAA, sulfynil acetic acid; <, less than; --, no data]

\begin{tabular}{|c|c|c|c|c|c|c|c|c|c|}
\hline \multirow{2}{*}{$\begin{array}{c}\text { Map } \\
\text { number } \\
\text { (fig. 4) }\end{array}$} & \multirow{2}{*}{$\begin{array}{l}\text { U.S. Geo- } \\
\text { logical } \\
\text { Survey site } \\
\text { identifica- } \\
\text { tion number }\end{array}$} & \multirow[b]{2}{*}{ Site name } & \multirow{2}{*}{$\begin{array}{c}\text { Date of } \\
\text { collection } \\
\text { (month/ } \\
\text { day/ } \\
\text { year) }\end{array}$} & \multirow[b]{2}{*}{$\begin{array}{l}\text { Collec- } \\
\text { tion time } \\
\text { (24-hour) }\end{array}$} & \multicolumn{5}{|c|}{ Concentrations, in micrograms per liter } \\
\hline & & & & & $\begin{array}{c}\text { Ala- } \\
\text { chlor } \\
\text { OXA }\end{array}$ & $\begin{array}{l}\text { Ala- } \\
\text { chlor } \\
\text { SAA }\end{array}$ & $\begin{array}{l}\text { Ala- } \\
\text { chlor } \\
\text { 2nd } \\
\text { amide }\end{array}$ & $\begin{array}{l}\text { Ala- } \\
\text { chlor } \\
\text { ESA - 2nd } \\
\text { amide }\end{array}$ & $\begin{array}{l}\text { Dimeth- } \\
\text { enamid }\end{array}$ \\
\hline \multirow[t]{4}{*}{6} & 6485500 & Big Sioux River at Akron & $04 / 13 / 04$ & 0930 & 0.03 & $<0.02$ & $<0.02$ & $<0.02$ & $<0.02$ \\
\hline & & & $05 / 12 / 04$ & 1030 & .02 & $<.02$ & $<.02$ & $<.02$ & $<.02$ \\
\hline & & & $06 / 02 / 04$ & 1215 & .03 & $<.02$ & $<.02$ & $<.02$ & .15 \\
\hline & & & $07 / 14 / 04$ & 1030 & $<.02$ & $<.02$ & $<.02$ & $<.02$ & $<.02$ \\
\hline \multirow[t]{4}{*}{7} & 6607500 & Little Sioux River near Turin & $03 / 10 / 04$ & 0830 & .05 & $<.02$ & -- & $<.02$ & $<.02$ \\
\hline & & & 06/08/04 & 0850 & .02 & $<.02$ & $<.02$ & $<.02$ & $<.02$ \\
\hline & & & $06 / 17 / 04$ & 1230 & $<.02$ & $<.02$ & $<.02$ & $<.02$ & .02 \\
\hline & & & 07/13/04 & 1000 & $<.02$ & $<.02$ & $<.02$ & $<.02$ & $<.02$ \\
\hline \multirow[t]{3}{*}{8} & 6609500 & Boyer River at Logan & $04 / 14 / 04$ & 0730 & .06 & $<.02$ & $<.02$ & $<.02$ & $<.02$ \\
\hline & & & 05/11/04 & 1300 & .05 & $<.02$ & $<.02$ & $<.02$ & $<.02$ \\
\hline & & & 05/23/04 & 1015 & .02 & .26 & $<.02$ & $<.02$ & .23 \\
\hline \multirow{6}{*}{9} & & & $03 / 29 / 04$ & 1230 & .02 & $<.02$ & -- & $<.02$ & $<.02$ \\
\hline & & & $04 / 12 / 04$ & 1300 & .03 & $<.02$ & $<.02$ & $<.02$ & $<.02$ \\
\hline & & & 05/10/04 & 1230 & .02 & .06 & $<.02$ & $<.02$ & .52 \\
\hline & & & $05 / 25 / 04$ & 1045 & .03 & .15 & $<.02$ & $<.02$ & .38 \\
\hline & & & 06/07/04 & 1245 & .02 & $<.02$ & $<.02$ & $<.02$ & .02 \\
\hline & & & $07 / 12 / 04$ & 1230 & $<.02$ & $<.02$ & $<.02$ & $<.02$ & $<.02$ \\
\hline \multirow[t]{5}{*}{10} & 6904010 & Chariton River near Moulton & 03/18/04 & 0900 & .04 & $<.02$ & -- & .96 & .03 \\
\hline & & & $04 / 22 / 04$ & 1320 & .02 & $<.02$ & $<.02$ & $<.02$ & $<.02$ \\
\hline & & & 05/17/04 & 1100 & .02 & $<.02$ & $<.02$ & $<.02$ & $<.02$ \\
\hline & & & $06 / 14 / 04$ & 1050 & .02 & $<.02$ & $<.02$ & $<.02$ & .03 \\
\hline & & & 07/19/04 & 1230 & .02 & $<.02$ & $<.02$ & $<.02$ & $<.02$ \\
\hline
\end{tabular}


Table 8. Concentrations of acetamide herbicides and their degradation products analyzed by the U.S. Geological Survey Organic Geochemistry Research Laboratory, Lawrence, Kansas, for water samples collected from 10 rivers in lowa, 2004.-Continued

[ESA, ethanesulfonic acid; OXA, oxanilic acid; SAA, sulfynil acetic acid; <, less than; --, no data]

\begin{tabular}{|c|c|c|c|c|c|c|c|c|}
\hline \multirow[b]{2}{*}{$\begin{array}{c}\text { Map } \\
\text { number } \\
\text { (fig. 4) }\end{array}$} & \multirow[b]{2}{*}{$\begin{array}{l}\text { U.S. Geological } \\
\text { Survey site } \\
\text { identifica- } \\
\text { tion number }\end{array}$} & \multirow[b]{2}{*}{ Site name } & \multirow[b]{2}{*}{$\begin{array}{c}\text { Date of } \\
\text { collection } \\
\text { (month/day/ } \\
\text { year) }\end{array}$} & \multirow[b]{2}{*}{$\begin{array}{c}\text { Collection } \\
\text { time } \\
\text { (24-hour) }\end{array}$} & \multicolumn{4}{|c|}{ Concentrations, in micrograms per liter } \\
\hline & & & & & $\begin{array}{l}\text { Dimeth- } \\
\text { enamid } \\
\text { deschloro }\end{array}$ & $\begin{array}{c}\text { Dimeth- } \\
\text { enamid } \\
\text { ESA }\end{array}$ & $\begin{array}{l}\text { Dimeth- } \\
\text { enamid } \\
\text { hydroxy }\end{array}$ & $\begin{array}{l}\text { Dimethen- } \\
\text { amid } \\
\text { OXA }\end{array}$ \\
\hline \multirow[t]{6}{*}{1} & 5412500 & Turkey River at Garber & $3 / 15 / 2004$ & 1100 & -- & 0.05 & -- & $<0.02$ \\
\hline & & & $4 / 20 / 2004$ & 950 & -- & $<.02$ & -- & $<.02$ \\
\hline & & & $5 / 19 / 2004$ & 1200 & $<0.02$ & .10 & -- & .08 \\
\hline & & & $5 / 24 / 2004$ & 1115 & $<.02$ & .17 & -- & .34 \\
\hline & & & $6 / 10 / 2004$ & 1000 & $<.02$ & .13 & -- & .07 \\
\hline & & & $7 / 21 / 2004$ & 1130 & $<.02$ & $<.02$ & $<0.02$ & $<.02$ \\
\hline \multirow[t]{7}{*}{2} & 5418600 & Maquoketa River near Spragueville & $3 / 15 / 2004$ & 1700 & -- & .06 & -- & .02 \\
\hline & & & $3 / 29 / 2004$ & 1500 & -- & .07 & -- & $<.02$ \\
\hline & & & $4 / 20 / 2004$ & 1510 & -- & .02 & -- & $<.02$ \\
\hline & & & $5 / 19 / 2004$ & 800 & $<.02$ & .02 & -- & .02 \\
\hline & & & $5 / 25 / 2004$ & 1015 & $<.02$ & .18 & -- & .15 \\
\hline & & & $6 / 10 / 2004$ & 1300 & $<.02$ & .08 & -- & .03 \\
\hline & & & $7 / 21 / 2004$ & 720 & $<.02$ & .10 & $<.02$ & .02 \\
\hline \multirow[t]{6}{*}{3} & 5422000 & Wapsipinicon River near DeWitt & $3 / 17 / 2004$ & 830 & -- & .10 & -- & .03 \\
\hline & & & $4 / 15 / 2004$ & 830 & -- & .05 & -- & $<.02$ \\
\hline & & & $5 / 18 / 2004$ & 1200 & $<.02$ & .12 & -- & .16 \\
\hline & & & $5 / 25 / 2004$ & 1430 & $<.02$ & .18 & -- & .12 \\
\hline & & & $06 / 16 / 04$ & 1230 & $<.02$ & 0.21 & -- & 0.07 \\
\hline & & & $07 / 20 / 04$ & 1200 & $<.02$ & 60 & $<.02$ & .06 \\
\hline \multirow[t]{5}{*}{4} & 5474000 & Skunk River at Augusta & $03 / 17 / 04$ & 1430 & -- & .06 & -- & .02 \\
\hline & & & $04 / 15 / 04$ & 1345 & -- & .03 & -- & $<.02$ \\
\hline & & & $05 / 18 / 04$ & 0730 & $<.02$ & .06 & -- & .05 \\
\hline & & & 06/16/04 & 0900 & $<.02$ & .17 & -- & .15 \\
\hline & & & $07 / 20 / 04$ & 0800 & $<.02$ & .12 & $<.02$ & .03 \\
\hline \multirow[t]{5}{*}{5} & 5490500 & Des Moines River at Keosauqua & $03 / 18 / 04$ & 1230 & -- & .06 & -- & .02 \\
\hline & & & $04 / 22 / 04$ & 0910 & -- & .03 & -- & $<.02$ \\
\hline & & & $05 / 17 / 04$ & 1400 & $<.02$ & .04 & -- & $<.02$ \\
\hline & & & $06 / 14 / 04$ & 1400 & $<.02$ & .14 & -- & .10 \\
\hline & & & 07/19/04 & 1600 & $<.02$ & .14 & $<.02$ & .04 \\
\hline
\end{tabular}


Table 8. Concentrations of acetamide herbicides and their degradation products analyzed by the U.S. Geological Survey Organic Geochemistry Research Laboratory, Lawrence, Kansas, for water samples collected from 10 rivers in lowa, 2004.-Continued

[ESA, ethanesulfonic acid; OXA, oxanilic acid; SAA, sulfynil acetic acid; <, less than; --, no data]

\begin{tabular}{|c|c|c|c|c|c|c|c|c|}
\hline \multirow[b]{2}{*}{$\begin{array}{c}\text { Map } \\
\text { number } \\
\text { (fig. 4) }\end{array}$} & \multirow{2}{*}{$\begin{array}{l}\text { U.S. Geological } \\
\text { Survey site } \\
\text { identifica- } \\
\text { tion number }\end{array}$} & \multirow[b]{2}{*}{ Site name } & \multirow{2}{*}{$\begin{array}{c}\text { Date of } \\
\text { collection } \\
\text { (month/day/ } \\
\text { year) }\end{array}$} & \multirow[b]{2}{*}{$\begin{array}{l}\text { Collection } \\
\text { time } \\
\text { (24-hour) }\end{array}$} & \multicolumn{4}{|c|}{ Concentrations, in micrograms per liter } \\
\hline & & & & & $\begin{array}{c}\text { Dimeth- } \\
\text { enamid } \\
\text { deschloro }\end{array}$ & $\begin{array}{c}\text { Dimeth- } \\
\text { enamid } \\
\text { ESA }\end{array}$ & $\begin{array}{l}\text { Dimeth- } \\
\text { enamid } \\
\text { hydroxy }\end{array}$ & $\begin{array}{c}\text { Dimethen- } \\
\text { amid } \\
\text { OXA }\end{array}$ \\
\hline \multirow[t]{6}{*}{6} & 6485500 & Big Sioux River at Akron & 03/09/04 & 1200 & -- & 0.12 & -- & 0.07 \\
\hline & & & $04 / 13 / 04$ & 0930 & -- & .02 & -- & $<.02$ \\
\hline & & & $05 / 12 / 04$ & 1030 & $<0.02$ & $<.02$ & -- & $<.02$ \\
\hline & & & $05 / 26 / 04$ & 1300 & $<.02$ & .02 & -- & .04 \\
\hline & & & $06 / 02 / 04$ & 1215 & $<.02$ & .05 & -- & .04 \\
\hline & & & $07 / 14 / 04$ & 1030 & $<.02$ & .03 & $<0.02$ & $<.02$ \\
\hline \multirow[t]{7}{*}{7} & 6607500 & Little Sioux River near Turin & 03/10/04 & 0830 & -- & $<.02$ & -- & $<.02$ \\
\hline & & & $04 / 13 / 04$ & 1400 & -- & $<.02$ & -- & $<.02$ \\
\hline & & & $05 / 11 / 04$ & 1020 & $<.02$ & $<.02$ & -- & $<.02$ \\
\hline & & & $05 / 24 / 04$ & 1100 & $<.02$ & $<.02$ & -- & $<.02$ \\
\hline & & & 06/08/04 & 0850 & $<.02$ & $<.02$ & -- & $<.02$ \\
\hline & & & $06 / 17 / 04$ & 1230 & $<.02$ & .02 & -- & $<.02$ \\
\hline & & & 07/13/04 & 1000 & $<.02$ & $<.02$ & $<.02$ & $<.02$ \\
\hline \multirow[t]{6}{*}{8} & 6609500 & Boyer River at Logan & $04 / 14 / 04$ & 0730 & -- & $<.02$ & -- & $<.02$ \\
\hline & & & $05 / 11 / 04$ & 1300 & $<.02$ & $<.02$ & -- & $<.02$ \\
\hline & & & $05 / 23 / 04$ & 1015 & $<.02$ & .03 & -- & .05 \\
\hline & & & 06/08/04 & 1130 & $<.02$ & $<.02$ & -- & $<.02$ \\
\hline & & & $06 / 17 / 04$ & 1000 & $<.02$ & $<.02$ & -- & $<.02$ \\
\hline & & & $07 / 13 / 04$ & 1230 & $<.02$ & $<.02$ & $<.02$ & $<.02$ \\
\hline \multirow[t]{7}{*}{9} & 6810000 & Nishnabotna River above Hamburg & $03 / 11 / 04$ & 1030 & -- & $<.02$ & -- & $<.02$ \\
\hline & & & $03 / 29 / 04$ & 1230 & -- & .02 & -- & $<.02$ \\
\hline & & & $04 / 12 / 04$ & 1300 & -- & $<.02$ & -- & $<.02$ \\
\hline & & & $05 / 10 / 04$ & 1230 & $<.02$ & .02 & -- & $<.02$ \\
\hline & & & $05 / 25 / 04$ & 1045 & .03 & .06 & -- & .14 \\
\hline & & & 06/07/04 & 1245 & $<.02$ & .02 & $<.02$ & $<.02$ \\
\hline & & & $07 / 12 / 04$ & 1230 & $<.02$ & .02 & $<.02$ & $<.02$ \\
\hline \multirow[t]{5}{*}{10} & 6904010 & Chariton River near Moulton & $03 / 18 / 04$ & 0900 & -- & .06 & -- & .05 \\
\hline & & & $04 / 22 / 04$ & 1320 & -- & $<.02$ & -- & $<.02$ \\
\hline & & & $05 / 17 / 04$ & 1100 & $<.02$ & .03 & -- & .02 \\
\hline & & & $06 / 14 / 04$ & 1050 & $<.02$ & .09 & -- & .08 \\
\hline & & & $07 / 19 / 04$ & 1230 & $<.02$ & .06 & $<.02$ & .04 \\
\hline
\end{tabular}


Table 8. Concentrations of acetamide herbicides and their degradation products analyzed by the U.S. Geological Survey Organic Geochemistry Research Laboratory, Lawrence, Kansas, for water samples collected from 10 rivers in lowa, 2004.-Continued

[ESA, ethanesulfonic acid; OXA, oxanilic acid; SAA, sulfynil acetic acid; <, less than; --, no data]

\begin{tabular}{|c|c|c|c|c|c|c|c|c|c|}
\hline \multirow[b]{2}{*}{$\begin{array}{c}\text { Map } \\
\text { number } \\
\text { (fig. 4) }\end{array}$} & \multirow{2}{*}{$\begin{array}{l}\text { U.S. Geo- } \\
\text { logical } \\
\text { Survey site } \\
\text { identifica- } \\
\text { tion number }\end{array}$} & \multirow[b]{2}{*}{ Site name } & \multirow[b]{2}{*}{$\begin{array}{c}\text { Date of } \\
\text { collection } \\
\text { (month/day/ } \\
\text { year) }\end{array}$} & \multirow[b]{2}{*}{$\begin{array}{l}\text { Collection } \\
\text { time } \\
\text { (24-hour) }\end{array}$} & \multicolumn{5}{|c|}{ Concentrations, in micrograms per liter } \\
\hline & & & & & $\begin{array}{c}\text { Flu- } \\
\text { fena- } \\
\text { cet }\end{array}$ & $\begin{array}{c}\text { Flu- } \\
\text { fena- } \\
\text { cet } \\
\text { ESA }\end{array}$ & $\begin{array}{c}\text { Flu- } \\
\text { fena- } \\
\text { cet } \\
\text { OXA }\end{array}$ & $\begin{array}{l}\text { Metol- } \\
\text { achlor }\end{array}$ & $\begin{array}{c}\text { Metol- } \\
\text { achlor } \\
\text { des- } \\
\text { chloro }\end{array}$ \\
\hline \multirow[t]{5}{*}{1} & 5412500 & Turkey River at Garber & $03 / 15 / 04$ & 1100 & $<0.02$ & $<0.02$ & $<0.02$ & 0.07 & -- \\
\hline & & & $04 / 20 / 04$ & 0950 & $<.02$ & $<.02$ & $<.02$ & $<.02$ & -- \\
\hline & & & $05 / 24 / 04$ & 1115 & $<.02$ & .03 & .02 & .07 & $<.02$ \\
\hline & & & $06 / 10 / 04$ & 1000 & $<.02$ & $<.02$ & $<.02$ & .40 & $<.02$ \\
\hline & & & $07 / 21 / 04$ & 1130 & $<.02$ & $<.02$ & $<.02$ & .02 & $<.02$ \\
\hline \multirow{5}{*}{2} & & & $04 / 20 / 04$ & 1510 & $<.02$ & $<.02$ & $<.02$ & .02 & -- \\
\hline & & & 05/19/04 & 0800 & .13 & $<.02$ & $<.02$ & .22 & $<.02$ \\
\hline & & & $05 / 25 / 04$ & 1015 & $<.02$ & $<.02$ & $<.02$ & 3.3 & $<.02$ \\
\hline & & & $06 / 10 / 04$ & 1300 & $<.02$ & $<.02$ & $<.02$ & .10 & $<.02$ \\
\hline & & & $07 / 21 / 04$ & 0720 & $<.02$ & $<.02$ & $<.02$ & .03 & $<.02$ \\
\hline 3 & 5422000 & Wapsipinicon River near DeWitt & $03 / 17 / 04$ & 0830 & $<.02$ & $<.02$ & $<.02$ & .09 & -- \\
\hline \multirow[t]{5}{*}{4} & 5474000 & Skunk River at Augusta & 03/17/04 & 1430 & $<.02$ & $<.02$ & $<.02$ & .17 & -- \\
\hline & & & $04 / 15 / 04$ & 1345 & $<.02$ & $<.02$ & $<.02$ & .06 & -- \\
\hline & & & 05/18/04 & 0730 & $<.02$ & $<.02$ & $<.02$ & 1.2 & $<.02$ \\
\hline & & & 06/16/04 & 0900 & .19 & .16 & .12 & .84 & $<.02$ \\
\hline & & & 07/20/04 & 0800 & $<.02$ & $<.02$ & $<.02$ & .15 & $<.02$ \\
\hline \multirow[t]{5}{*}{5} & 5490500 & Des Moines River at Keosauqua & 03/18/04 & 1230 & .03 & .02 & $<.02$ & 1.1 & -- \\
\hline & & & $04 / 22 / 04$ & 0910 & $<.02$ & $<.02$ & $<.02$ & .25 & -- \\
\hline & & & 05/17/04 & 1400 & $<.02$ & $<.02$ & $<.02$ & .66 & $<.02$ \\
\hline & & & $06 / 14 / 04$ & 1400 & .05 & $<.02$ & $<.02$ & .64 & $<.02$ \\
\hline & & & 07/19/04 & 1600 & $<.02$ & $<.02$ & $<.02$ & .23 & $<.02$ \\
\hline
\end{tabular}


Table 8. Concentrations of acetamide herbicides and their degradation products analyzed by the U.S. Geological Survey Organic Geochemistry Research Laboratory, Lawrence, Kansas, for water samples collected from 10 rivers in lowa, 2004.-Continued

[ESA, ethanesulfonic acid; OXA, oxanilic acid; SAA, sulfynil acetic acid; <, less than; --, no data]

\begin{tabular}{|c|c|c|c|c|c|c|c|c|c|}
\hline \multirow[b]{2}{*}{$\begin{array}{c}\text { Map } \\
\text { number } \\
\text { (fig. 4) }\end{array}$} & \multirow{2}{*}{$\begin{array}{l}\text { U.S. Geo- } \\
\text { logical } \\
\text { Survey site } \\
\text { identifica- } \\
\text { tion number }\end{array}$} & \multirow[b]{2}{*}{ Site name } & \multirow[b]{2}{*}{$\begin{array}{c}\text { Date of } \\
\text { collection } \\
\text { (month/day/ } \\
\text { year) }\end{array}$} & \multirow[b]{2}{*}{$\begin{array}{l}\text { Collection } \\
\text { time } \\
\text { (24-hour) }\end{array}$} & \multicolumn{5}{|c|}{ Concentrations, in micrograms per liter } \\
\hline & & & & & $\begin{array}{c}\text { Flu- } \\
\text { fena- } \\
\text { cet }\end{array}$ & $\begin{array}{c}\text { Flu- } \\
\text { fena- } \\
\text { cet } \\
\text { ESA }\end{array}$ & $\begin{array}{l}\text { Flu- } \\
\text { fena- } \\
\text { cet } \\
\text { OXA }\end{array}$ & $\begin{array}{l}\text { Metol- } \\
\text { achlor }\end{array}$ & $\begin{array}{l}\text { Metol- } \\
\text { achlor } \\
\text { des- } \\
\text { chloro }\end{array}$ \\
\hline \multirow[t]{5}{*}{6} & 6485500 & Big Sioux River at Akron & 03/09/04 & 1200 & $<0.02$ & $<0.02$ & $<0.02$ & 1.5 & -- \\
\hline & & & 04/13/04 & 0930 & $<.02$ & $<.02$ & $<.02$ & .08 & -- \\
\hline & & & $05 / 26 / 04$ & 1300 & $<.02$ & $<.02$ & $<.02$ & .31 & $<.02$ \\
\hline & & & $06 / 02 / 04$ & 1215 & .03 & $<.02$ & $<.02$ & .58 & $<.02$ \\
\hline & & & $07 / 14 / 04$ & 1030 & $<.02$ & $<.02$ & $<.02$ & .03 & $<.02$ \\
\hline \multirow{5}{*}{7} & & & 05/11/04 & 1020 & .16 & $<.02$ & $<.02$ & .40 & $<.02$ \\
\hline & & & $05 / 24 / 04$ & 1100 & .20 & $<.02$ & $<.02$ & 1.1 & $<.02$ \\
\hline & & & 06/08/04 & 0850 & $<.02$ & $<.02$ & $<.02$ & .09 & $<.02$ \\
\hline & & & 06/17/04 & 1230 & .12 & $<.02$ & $<.02$ & .45 & $<.02$ \\
\hline & & & 07/13/04 & 1000 & $<.02$ & $<.02$ & $<.02$ & .04 & $<.02$ \\
\hline 8 & 6609500 & Boyer River at Logan & $04 / 14 / 04$ & 0730 & $<.02$ & $<.02$ & $<.02$ & .02 & -- \\
\hline \multirow[t]{7}{*}{9} & 6810000 & Nishnabotna River above Hamburg & 03/11/04 & 1030 & $<.02$ & $<.02$ & $<.02$ & .03 & -- \\
\hline & & & $03 / 29 / 04$ & 1230 & $<.02$ & $<.02$ & $<.02$ & .05 & -- \\
\hline & & & $04 / 12 / 04$ & 1300 & $<.02$ & $<.02$ & $<.02$ & .02 & -- \\
\hline & & & 05/10/04 & 1230 & .68 & $<.02$ & $<.02$ & .88 & $<.02$ \\
\hline & & & $05 / 25 / 04$ & 1045 & .20 & .02 & .02 & 2.4 & $<.02$ \\
\hline & & & 06/07/04 & 1245 & .02 & .02 & $<.02$ & .11 & $<.02$ \\
\hline & & & $07 / 12 / 04$ & 1230 & $<.02$ & $<.02$ & $<.02$ & .08 & $<.02$ \\
\hline \multirow[t]{5}{*}{10} & 6904010 & Chariton River near Moulton & 03/18/04 & 0900 & $<.02$ & $<.02$ & $<.02$ & .10 & -- \\
\hline & & & $04 / 22 / 04$ & 1320 & $<.02$ & $<.02$ & $<.02$ & .04 & -- \\
\hline & & & $05 / 17 / 04$ & 1100 & $<.02$ & $<.02$ & $<.02$ & .07 & .06 \\
\hline & & & 06/14/04 & 1050 & $<.02$ & $<.02$ & $<.02$ & .17 & .04 \\
\hline & & & $07 / 19 / 04$ & 1230 & $<.02$ & $<.02$ & $<.02$ & .32 & .08 \\
\hline
\end{tabular}


Table 8. Concentrations of acetamide herbicides and their degradation products analyzed by the U.S. Geological Survey Organic Geochemistry Research Laboratory, Lawrence, Kansas, for water samples collected from 10 rivers in lowa, 2004.-Continued

[ESA, ethanesulfonic acid; OXA, oxanilic acid; SAA, sulfynil acetic acid; <, less than; --, no data]

\begin{tabular}{|c|c|c|c|c|c|c|c|c|c|c|}
\hline \multirow[b]{2}{*}{$\begin{array}{c}\text { Map } \\
\text { number } \\
\text { (fig. 4) }\end{array}$} & \multirow{2}{*}{$\begin{array}{l}\text { U.S. Geo- } \\
\text { logical } \\
\text { Survey site } \\
\text { identifica- } \\
\text { tion number }\end{array}$} & \multirow[b]{2}{*}{ Site name } & \multirow{2}{*}{$\begin{array}{c}\text { Date of } \\
\text { collection } \\
\text { (month/ } \\
\text { day/ } \\
\text { year) }\end{array}$} & \multirow{2}{*}{$\begin{array}{c}\text { Collec- } \\
\text { tion } \\
\text { time } \\
\text { (24-hour) }\end{array}$} & \multicolumn{6}{|c|}{ Concentrations, in micrograms per liter } \\
\hline & & & & & $\begin{array}{l}\text { Metol- } \\
\text { achlor } \\
\text { ESA }\end{array}$ & $\begin{array}{l}\text { Metol- } \\
\text { achlor } \\
\text { hydroxy }\end{array}$ & $\begin{array}{c}\text { Metol- } \\
\text { achlor } \\
\text { OXA }\end{array}$ & $\begin{array}{l}\text { Propa- } \\
\text { chlor }\end{array}$ & $\begin{array}{l}\text { Propa- } \\
\text { chlor } \\
\text { ESA }\end{array}$ & $\begin{array}{c}\text { Propa- } \\
\text { chlor } \\
\text { OXA }\end{array}$ \\
\hline \multirow[t]{6}{*}{1} & 5412500 & Turkey River at Garber & 03/15/04 & 1100 & 0.30 & -- & 0.12 & $<0.02$ & $<0.05$ & $<0.02$ \\
\hline & & & 04/20/04 & 0950 & .88 & -- & .08 & $<.02$ & $<.05$ & $<.02$ \\
\hline & & & 05/19/04 & 1200 & 1.3 & -- & .22 & $<.02$ & $<.05$ & $<.02$ \\
\hline & & & 05/24/04 & 1115 & 1.6 & -- & .49 & $<.02$ & $<.05$ & $<.02$ \\
\hline & & & 06/10/04 & 1000 & .69 & -- & .16 & $<.02$ & $<.05$ & $<.02$ \\
\hline & & & 07/21/04 & 1130 & .75 & $<0.02$ & .07 & $<.02$ & $<.05$ & $<.02$ \\
\hline \multirow[t]{7}{*}{2} & 5418600 & Maquoketa River near Spragueville & 03/15/04 & 1700 & 1.2 & -- & .21 & $<.02$ & $<.05$ & $<.02$ \\
\hline & & & 03/29/04 & 1500 & 1.6 & -- & .32 & $<.02$ & $<.05$ & $<.02$ \\
\hline & & & 04/20/04 & 1510 & 1.9 & -- & .17 & $<.02$ & $<.05$ & $<.02$ \\
\hline & & & 05/19/04 & 0800 & 1.5 & -- & .16 & $<.02$ & $<.05$ & $<.02$ \\
\hline & & & $05 / 25 / 04$ & 1015 & 1.0 & -- & .49 & $<.02$ & $<.05$ & $<.02$ \\
\hline & & & 06/10/04 & 1300 & 1.7 & -- & .25 & $<.02$ & $<.05$ & $<.02$ \\
\hline & & & 07/21/04 & 0720 & 1.6 & $<.02$ & .15 & $<.02$ & $<.05$ & $<.02$ \\
\hline \multirow[t]{6}{*}{3} & 5422000 & Wapsipinicon River near DeWitt & 03/17/04 & 0830 & 1.3 & -- & .30 & $<.02$ & $<.05$ & $<.02$ \\
\hline & & & $04 / 15 / 04$ & 0830 & 1.7 & -- & .26 & $<.02$ & $<.05$ & $<.02$ \\
\hline & & & 05/18/04 & 1200 & 1.5 & -- & .40 & $<.02$ & $<.05$ & $<.02$ \\
\hline & & & $05 / 25 / 04$ & 1430 & 2.0 & -- & .87 & $<.02$ & $<.05$ & $<.02$ \\
\hline & & & $06 / 16 / 04$ & 1230 & 2.2 & -- & .51 & $<.02$ & $<.05$ & $<.02$ \\
\hline & & & 07/20/04 & 1200 & 2.9 & .03 & .33 & $<.02$ & $<.05$ & $<.02$ \\
\hline \multirow[t]{5}{*}{4} & 5474000 & Skunk River at Augusta & 03/17/04 & 1430 & .84 & -- & .31 & $<.02$ & $<.05$ & $<.02$ \\
\hline & & & $04 / 15 / 04$ & 1345 & .97 & -- & .23 & $<.02$ & $<.05$ & $<.02$ \\
\hline & & & 05/18/04 & 0730 & 1.1 & -- & .29 & $<.02$ & $<.05$ & $<.02$ \\
\hline & & & 06/16/04 & 0900 & 1.6 & -- & 1.1 & $<.02$ & $<.05$ & $<.02$ \\
\hline & & & 07/20/04 & 0800 & 2.0 & .05 & .36 & $<.02$ & $<.05$ & $<.02$ \\
\hline \multirow[t]{5}{*}{5} & 5490500 & Des Moines River at Keosauqua & 03/18/04 & 1230 & .42 & -- & .36 & $<.02$ & $<.05$ & $<.02$ \\
\hline & & & $04 / 22 / 04$ & 0910 & 1.3 & -- & .38 & $<.02$ & $<.05$ & $<.02$ \\
\hline & & & 05/17/04 & 1400 & .86 & -- & .24 & $<.02$ & $<.05$ & $<.02$ \\
\hline & & & $06 / 14 / 04$ & 1400 & 1.1 & -- & .45 & $<.02$ & $<.05$ & $<.02$ \\
\hline & & & 07/19/04 & 1600 & 1.5 & .07 & .32 & $<.02$ & $<.05$ & $<.02$ \\
\hline 6 & 6485500 & Big Sioux River at Akron & 03/9/04 & 1200 & 1.1 & -- & .99 & $<.02$ & $<.05$ & $<.02$ \\
\hline
\end{tabular}


Table 8. Concentrations of acetamide herbicides and their degradation products analyzed by the U.S. Geological Survey Organic Geochemistry Research Laboratory, Lawrence, Kansas, for water samples collected from 10 rivers in lowa, 2004.-Continued

[ESA, ethanesulfonic acid; OXA, oxanilic acid; SAA, sulfynil acetic acid; <, less than; --, no data]

\begin{tabular}{|c|c|c|c|c|c|c|c|c|c|c|}
\hline \multirow[b]{2}{*}{$\begin{array}{c}\text { Map } \\
\text { number } \\
\text { (fig. 4) }\end{array}$} & \multirow{2}{*}{$\begin{array}{l}\text { U.S. Geo- } \\
\text { logical } \\
\text { Survey site } \\
\text { identifica- } \\
\text { tion number }\end{array}$} & \multirow[b]{2}{*}{ Site name } & \multirow{2}{*}{$\begin{array}{c}\text { Date of } \\
\text { collection } \\
\text { (month/ } \\
\text { day/ } \\
\text { year) }\end{array}$} & \multirow{2}{*}{$\begin{array}{l}\text { Collec- } \\
\text { tion } \\
\text { time } \\
\text { (24-hour) }\end{array}$} & \multicolumn{6}{|c|}{ Concentrations, in micrograms per liter } \\
\hline & & & & & $\begin{array}{l}\text { Metol- } \\
\text { achlor } \\
\text { ESA }\end{array}$ & $\begin{array}{l}\text { Metol- } \\
\text { achlor } \\
\text { hydroxy }\end{array}$ & $\begin{array}{l}\text { Metol- } \\
\text { achlor } \\
\text { OXA }\end{array}$ & $\begin{array}{c}\text { Propa- } \\
\text { chlor }\end{array}$ & $\begin{array}{c}\text { Propa- } \\
\text { chlor } \\
\text { ESA }\end{array}$ & $\begin{array}{c}\text { Propa- } \\
\text { chlor } \\
\text { OXA }\end{array}$ \\
\hline \multirow[t]{5}{*}{6} & 6485500 & Big Sioux River at Akron & $4 / 13 / 04$ & 930 & 0.57 & -- & 0.14 & $<0.02$ & $<0.05$ & $<0.02$ \\
\hline & & & $5 / 12 / 04$ & 1030 & .40 & -- & .10 & $<.02$ & $<.05$ & $<.02$ \\
\hline & & & $5 / 26 / 04$ & 1300 & 1.2 & -- & .31 & $<.02$ & $<.05$ & $<.02$ \\
\hline & & & $6 / 2 / 04$ & 1215 & .50 & -- & .23 & $<.02$ & $<.05$ & $<.02$ \\
\hline & & & $7 / 14 / 04$ & 1030 & .63 & $<0.02$ & .13 & $<.02$ & $<.05$ & $<.02$ \\
\hline \multirow[t]{7}{*}{7} & 6607500 & Little Sioux River near Turin & 03/10/04 & 0830 & .39 & -- & .39 & $<.02$ & $<.05$ & $<.02$ \\
\hline & & & 04/13/04 & 1400 & .46 & -- & .15 & $<.02$ & $<.05$ & $<.02$ \\
\hline & & & 05/11/04 & 1020 & .41 & -- & .14 & $<.02$ & $<.05$ & $<.02$ \\
\hline & & & 05/24/04 & 1100 & .37 & -- & .22 & $<.02$ & $<.05$ & $<.02$ \\
\hline & & & 06/08/04 & 0850 & .61 & -- & .14 & $<.02$ & $<.05$ & $<.02$ \\
\hline & & & 06/17/04 & 1230 & .27 & -- & .20 & $<.02$ & $<.05$ & $<.02$ \\
\hline & & & 07/13/04 & 1000 & .67 & $<.02$ & .15 & $<.02$ & $<.05$ & $<.02$ \\
\hline \multirow[t]{6}{*}{8} & 6609500 & Boyer River at Logan & 04/14/04 & 0730 & .36 & -- & .19 & $<.02$ & $<.05$ & $<.02$ \\
\hline & & & 05/11/04 & 1300 & .30 & -- & .16 & $<.02$ & $<.05$ & $<.02$ \\
\hline & & & $05 / 23 / 04$ & 1015 & .51 & -- & .45 & $<.02$ & $<.05$ & $<.02$ \\
\hline & & & 06/08/04 & 1130 & .48 & -- & .15 & $<.02$ & $<.05$ & $<.02$ \\
\hline & & & 06/17/04 & 1000 & .38 & -- & .23 & $<.02$ & $<.05$ & $<.02$ \\
\hline & & & 07/13/04 & 1230 & .61 & $<.02$ & .14 & $<.02$ & $<.05$ & $<.02$ \\
\hline \multirow[t]{7}{*}{9} & 6810000 & Nishnabotna River above Hamburg & 03/11/04 & 1030 & .16 & -- & .13 & $<.02$ & $<.05$ & $<.02$ \\
\hline & & & 03/29/04 & 1230 & .33 & -- & .15 & $<.02$ & $<.05$ & $<.02$ \\
\hline & & & $04 / 12 / 04$ & 1300 & .31 & -- & .09 & $<.02$ & $<.05$ & $<.02$ \\
\hline & & & 05/10/04 & 1230 & .22 & -- & .09 & $<.02$ & $<.05$ & $<.02$ \\
\hline & & & $05 / 25 / 04$ & 1045 & .72 & -- & .63 & $<.02$ & $<.05$ & $<.02$ \\
\hline & & & 06/07/04 & 1245 & .28 & -- & .09 & $<.02$ & $<.05$ & $<.02$ \\
\hline & & & 07/12/04 & 1230 & .24 & $<.02$ & .12 & $<.02$ & $<.05$ & $<.02$ \\
\hline \multirow[t]{5}{*}{10} & 6904010 & Chariton River near Moulton & 03/18/04 & 0900 & .19 & -- & .41 & $<.02$ & $<.05$ & $<.02$ \\
\hline & & & $04 / 22 / 04$ & 1320 & .43 & -- & .32 & $<.02$ & $<.05$ & $<.02$ \\
\hline & & & 05/17/04 & 1100 & .23 & -- & .29 & $<.02$ & $<.05$ & $<.02$ \\
\hline & & & 06/14/04 & 1050 & .46 & -- & .51 & $<.02$ & $<.05$ & $<.02$ \\
\hline & & & 07/19/04 & 1230 & .55 & .23 & .51 & $<.02$ & $<.05$ & $<.02$ \\
\hline
\end{tabular}


Table 9. Concentrations of triazine and phenylurea herbicides and their degradation products analyzed by the U.S. Geological Survey Organic Geochemistry Research Laboratory, Lawrence, Kansas, for water samples collected from 10 rivers in lowa, 2004.

$[<$, less than; --, no data $]$

\begin{tabular}{|c|c|c|c|c|c|c|c|c|}
\hline \multirow[b]{2}{*}{$\begin{array}{c}\text { Map } \\
\text { number } \\
\text { (fig. 4) }\end{array}$} & \multirow{2}{*}{$\begin{array}{l}\text { U.S. Geo- } \\
\text { logical } \\
\text { Survey site } \\
\text { identifica- } \\
\text { tion number }\end{array}$} & \multirow[b]{2}{*}{ Site name } & \multirow[b]{2}{*}{$\begin{array}{c}\text { Date of } \\
\text { collection } \\
\text { (month/day/ } \\
\text { year) }\end{array}$} & \multirow[b]{2}{*}{$\begin{array}{l}\text { Collection } \\
\text { time } \\
\text { (24-hour) }\end{array}$} & \multicolumn{4}{|c|}{ Concentration, in micrograms per liter } \\
\hline & & & & & $\begin{array}{l}\text { Atra- } \\
\text { zine }\end{array}$ & $\begin{array}{l}\text { Deethyl- } \\
\text { atrazine }\end{array}$ & $\begin{array}{l}\text { Deethyl- } \\
\text { hydroxy- } \\
\text { atrazine }\end{array}$ & $\begin{array}{l}\text { Deiso- } \\
\text { propyl- } \\
\text { atrazine }\end{array}$ \\
\hline \multirow[t]{7}{*}{1} & 05412500 & Turkey River at Garber & $03 / 15 / 04$ & 1100 & 0.04 & 0.07 & $<0.025$ & $<0.025$ \\
\hline & & & 04/20/04 & 0950 & .06 & .09 & $<.025$ & .03 \\
\hline & & & 05/19/04 & 1200 & 2.6 & .32 & $<.025$ & .14 \\
\hline & & & $05 / 24 / 04$ & 1115 & 3.4 & .65 & $<.025$ & .34 \\
\hline & & & 06/10/04 & 1000 & 1.2 & .28 & $<.025$ & .14 \\
\hline & & & $07 / 21 / 04$ & 1130 & .21 & .18 & $<.025$ & .08 \\
\hline & & & $09 / 14 / 04$ & 1300 & .06 & .11 & $<.025$ & .03 \\
\hline \multirow[t]{8}{*}{2} & 05418600 & Maquoketa River near Spragueville & $03 / 15 / 04$ & 1700 & $<.025$ & .08 & $<.025$ & $<.025$ \\
\hline & & & $03 / 29 / 04$ & 1500 & .03 & .09 & $<.025$ & $<.025$ \\
\hline & & & $04 / 20 / 04$ & 1510 & .06 & .10 & $<.025$ & .03 \\
\hline & & & 05/19/04 & 0800 & .88 & .20 & $<.025$ & .07 \\
\hline & & & $05 / 25 / 04$ & 1015 & 4.5 & .84 & $<.025$ & .50 \\
\hline & & & $06 / 10 / 04$ & 1300 & .33 & .16 & $<.025$ & .05 \\
\hline & & & $07 / 21 / 04$ & 0720 & .20 & .19 & $<.025$ & .08 \\
\hline & & & $09 / 14 / 04$ & 1000 & .04 & .12 & $<.025$ & .03 \\
\hline \multirow[t]{7}{*}{3} & 05422000 & Wapsipinicon River near DeWitt & $03 / 17 / 04$ & 0830 & $<.025$ & .06 & $<.025$ & $<.025$ \\
\hline & & & $04 / 15 / 04$ & 0830 & .03 & .08 & $<.025$ & .03 \\
\hline & & & 05/18/04 & 1200 & 5.8 & .41 & $<.025$ & .17 \\
\hline & & & $05 / 25 / 04$ & 1430 & 4.6 & .77 & $<.025$ & .45 \\
\hline & & & 06/16/04 & 1230 & 1.6 & .40 & $<.025$ & .15 \\
\hline & & & 07/20/04 & 1200 & .43 & .50 & $<.025$ & .21 \\
\hline & & & 09/14/04 & 0730 & .07 & .08 & $<.025$ & $<.025$ \\
\hline \multirow[t]{6}{*}{4} & 05474000 & Skunk River at Augusta & 03/17/04 & 1430 & .03 & .04 & $<.025$ & $<.025$ \\
\hline & & & $04 / 15 / 04$ & 1345 & .05 & .05 & $<.025$ & .03 \\
\hline & & & 05/18/04 & 0730 & 1.3 & .18 & $<.025$ & .08 \\
\hline & & & $06 / 16 / 04$ & 0900 & 1.2 & .70 & $<.025$ & .38 \\
\hline & & & 07/20/04 & 0800 & .30 & .18 & $<.025$ & .09 \\
\hline & & & 09/13/04 & 1530 & .07 & .06 & $<.025$ & $<.025$ \\
\hline
\end{tabular}


Table 9. Concentrations of triazine and phenylurea herbicides and their degradation products analyzed by the U.S. Geological Survey Organic Geochemistry Research Laboratory, Lawrence, Kansas, for water samples collected from 10 rivers in lowa, 2004.Continued

\begin{tabular}{|c|c|c|c|c|c|c|c|c|}
\hline \multirow[b]{2}{*}{$\begin{array}{c}\text { Map } \\
\text { number } \\
\text { (fig. 4) }\end{array}$} & \multirow{2}{*}{$\begin{array}{l}\text { U.S. Geo- } \\
\text { logical } \\
\text { Survey site } \\
\text { identifica- } \\
\text { tion number }\end{array}$} & \multirow[b]{2}{*}{ Site name } & \multirow[b]{2}{*}{$\begin{array}{c}\text { Date of } \\
\text { collection } \\
\text { (month/day/ } \\
\text { year) }\end{array}$} & \multirow[b]{2}{*}{$\begin{array}{l}\text { Collection } \\
\text { time } \\
\text { (24-hour) }\end{array}$} & \multicolumn{4}{|c|}{ Concentration, in micrograms per liter } \\
\hline & & & & & $\begin{array}{l}\text { Atra- } \\
\text { zine }\end{array}$ & $\begin{array}{l}\text { Deethyl- } \\
\text { atrazine }\end{array}$ & $\begin{array}{l}\text { Deethyl- } \\
\text { hydroxy- } \\
\text { atrazine }\end{array}$ & $\begin{array}{l}\text { Deiso- } \\
\text { propyl- } \\
\text { atrazine }\end{array}$ \\
\hline \multirow[t]{6}{*}{5} & 05490500 & Des Moines River at Keosauqua & 03/18/04 & 1230 & 0.05 & 0.04 & $<0.025$ & $<0.025$ \\
\hline & & & $04 / 22 / 04$ & 0910 & .07 & .04 & $<.025$ & .03 \\
\hline & & & 05/17/04 & 1400 & 1.3 & .10 & $<.025$ & .05 \\
\hline & & & 06/14/04 & 1400 & 1.2 & .31 & $<.025$ & .14 \\
\hline & & & 07/19/04 & 1600 & 1.2 & .34 & $<.025$ & .19 \\
\hline & & & 09/13/04 & 1330 & .18 & .09 & $<.025$ & .04 \\
\hline \multirow[t]{6}{*}{6} & 06485500 & Big Sioux River at Akron & 03/09/04 & 1200 & .06 & .06 & $<.025$ & $<.025$ \\
\hline & & & 04/13/04 & 0930 & .03 & $<.025$ & $<.025$ & $<.025$ \\
\hline & & & 05/12/04 & 1030 & .06 & .05 & $<.025$ & .05 \\
\hline & & & $05 / 26 / 04$ & 1300 & .38 & .07 & $<.025$ & .06 \\
\hline & & & 06/02/04 & 1215 & 1.3 & .27 & $<.025$ & .20 \\
\hline & & & $07 / 14 / 04$ & 1030 & .52 & .14 & $<.025$ & .11 \\
\hline \multirow[t]{7}{*}{7} & 06607500 & Little Sioux River near Turin & 03/10/04 & 0830 & .04 & .04 & $<.025$ & $<.025$ \\
\hline & & & 04/13/04 & 1400 & .03 & .03 & $<.025$ & $<.025$ \\
\hline & & & 05/11/04 & 1020 & 1.4 & .15 & $<.025$ & .08 \\
\hline & & & $05 / 24 / 04$ & 1100 & 3.3 & .47 & $<.025$ & .30 \\
\hline & & & 06/08/04 & 0850 & .23 & .07 & $<.025$ & .04 \\
\hline & & & 06/17/04 & 1230 & 8.2 & .46 & .09 & .29 \\
\hline & & & 07/13/04 & 1000 & .51 & .14 & $<.025$ & .08 \\
\hline \multirow[t]{7}{*}{8} & 06609500 & Boyer River at Logan & $03 / 12 / 04$ & 0930 & .03 & $<.025$ & $<.025$ & $<.025$ \\
\hline & & & $04 / 14 / 04$ & 0730 & .03 & .03 & $<.025$ & $<.025$ \\
\hline & & & 05/11/04 & 1300 & .32 & .09 & $<.025$ & .06 \\
\hline & & & $05 / 23 / 04$ & 1015 & 18 & 1.7 & $<.025$ & .94 \\
\hline & & & 06/08/04 & 1130 & .33 & .08 & $<.025$ & .04 \\
\hline & & & 06/17/04 & 1000 & 13 & .88 & .22 & .65 \\
\hline & & & 07/13/04 & 1230 & .25 & .12 & $<.025$ & .06 \\
\hline \multirow[t]{2}{*}{9} & 06810000 & Nishnabotna River above Hamburg & 03/11/04 & 1030 & $<.025$ & .03 & $<.025$ & $<.025$ \\
\hline & & & 03/29/04 & 1230 & .08 & .05 & $<.025$ & $<.025$ \\
\hline
\end{tabular}


Table 9. Concentrations of triazine and phenylurea herbicides and their degradation products analyzed by the U.S. Geological Survey Organic Geochemistry Research Laboratory, Lawrence, Kansas, for water samples collected from 10 rivers in lowa, 2004.Continued

$[<$, less than; --, no data]

\begin{tabular}{|c|c|c|c|c|c|c|c|c|}
\hline \multirow[b]{2}{*}{$\begin{array}{c}\text { Map } \\
\text { number } \\
\text { (fig. 4) }\end{array}$} & \multirow{2}{*}{$\begin{array}{l}\text { U.S. Geo- } \\
\text { logical } \\
\text { Survey site } \\
\text { identifica- } \\
\text { tion number }\end{array}$} & \multirow[b]{2}{*}{ Site name } & \multirow[b]{2}{*}{$\begin{array}{c}\text { Date of } \\
\text { collection } \\
\text { (month/day/ } \\
\text { year) }\end{array}$} & \multirow[b]{2}{*}{$\begin{array}{l}\text { Collection } \\
\text { time } \\
\text { (24-hour) }\end{array}$} & \multicolumn{4}{|c|}{ Concentration, in micrograms per liter } \\
\hline & & & & & $\begin{array}{l}\text { Atra- } \\
\text { zine }\end{array}$ & $\begin{array}{l}\text { Deethyl- } \\
\text { atrazine }\end{array}$ & $\begin{array}{l}\text { Deethyl- } \\
\text { hydroxy- } \\
\text { atrazine }\end{array}$ & $\begin{array}{l}\text { Deiso- } \\
\text { propyl- } \\
\text { atrazine }\end{array}$ \\
\hline \multirow[t]{5}{*}{9} & 06810000 & Nishnabotna River above Hamburg & $04 / 12 / 04$ & 1300 & 0.04 & 0.04 & $<0.025$ & $<0.025$ \\
\hline & & & $05 / 10 / 04$ & 1230 & 21 & .96 & $<.025$ & .37 \\
\hline & & & $05 / 25 / 04$ & 1045 & 5.1 & 1.2 & $<.025$ & .91 \\
\hline & & & 06/07/04 & 1245 & .50 & .14 & $<.025$ & .06 \\
\hline & & & $07 / 12 / 04$ & 1230 & .58 & .35 & $<.025$ & .16 \\
\hline \multirow[t]{6}{*}{10} & 06904010 & Chariton River near Moulton & $03 / 18 / 04$ & 0900 & .36 & .29 & $<.025$ & .09 \\
\hline & & & $04 / 22 / 04$ & 1320 & .23 & .18 & $<.025$ & .07 \\
\hline & & & 05/17/04 & 1100 & .29 & .21 & $<.025$ & .08 \\
\hline & & & $06 / 14 / 04$ & 1050 & .85 & .53 & $<.025$ & .20 \\
\hline & & & $07 / 19 / 04$ & 1230 & .86 & .67 & $<.025$ & .38 \\
\hline & & & 09/13/04 & 1030 & .56 & .38 & $<.025$ & .15 \\
\hline
\end{tabular}


Table 9. Concentrations of triazine and phenylurea herbicides and their degradation products analyzed by the U.S. Geological Survey Organic Geochemistry Research Laboratory, Lawrence, Kansas, for water samples collected from 10 rivers in lowa, 2004.-Continued

$[<$, less than; --, no data $]$

\begin{tabular}{|c|c|c|c|c|c|c|c|}
\hline \multirow[b]{2}{*}{$\begin{array}{c}\text { Map } \\
\text { number } \\
\text { (fig. 4) }\end{array}$} & \multirow{2}{*}{$\begin{array}{l}\text { U.S. Geo- } \\
\text { logical } \\
\text { Survey site } \\
\text { identifica- } \\
\text { tion number }\end{array}$} & \multirow[b]{2}{*}{ Site name } & \multirow[b]{2}{*}{$\begin{array}{c}\text { Date of } \\
\text { collection } \\
\text { (month/day/ } \\
\text { year) }\end{array}$} & \multirow[b]{2}{*}{$\begin{array}{l}\text { Collection } \\
\text { time } \\
\text { (24-hour) }\end{array}$} & \multicolumn{3}{|c|}{ Concentration, in micrograms per liter } \\
\hline & & & & & $\begin{array}{c}\text { Deiso- } \\
\text { propyl- } \\
\text { hydroxy- } \\
\text { atrazine }\end{array}$ & $\begin{array}{l}\text { Didealkyl- } \\
\text { atrazine }\end{array}$ & $\begin{array}{l}\text { Hydroxy- } \\
\text { atrazine }\end{array}$ \\
\hline \multirow[t]{7}{*}{1} & 05412500 & Turkey River at Garber & $03 / 15 / 04$ & 1100 & $<0.025$ & 0.10 & 0.04 \\
\hline & & & 04/20/04 & 0950 & $<.025$ & .12 & .04 \\
\hline & & & $05 / 19 / 04$ & 1200 & $<.025$ & .34 & .09 \\
\hline & & & $05 / 24 / 04$ & 1115 & $<.025$ & .43 & .28 \\
\hline & & & $06 / 10 / 04$ & 1000 & $<.025$ & .29 & .22 \\
\hline & & & $07 / 21 / 04$ & 1130 & .05 & $<.025$ & $<.025$ \\
\hline & & & 09/14/04 & 1300 & $<.025$ & .17 & .09 \\
\hline \multirow[t]{8}{*}{2} & 05418600 & Maquoketa River near Spragueville & $03 / 15 / 04$ & 1700 & $<.025$ & .10 & $<.025$ \\
\hline & & & $03 / 29 / 04$ & 1500 & $<.025$ & .13 & .05 \\
\hline & & & $04 / 20 / 04$ & 1510 & $<.025$ & .13 & .04 \\
\hline & & & $05 / 19 / 04$ & 0800 & $<.025$ & .18 & .06 \\
\hline & & & $05 / 25 / 04$ & 1015 & $<.025$ & .45 & .46 \\
\hline & & & 06/10/04 & 1300 & $<.025$ & .23 & .07 \\
\hline & & & $07 / 21 / 04$ & 0720 & $<.025$ & .28 & .09 \\
\hline & & & 09/14/04 & 1000 & $<.025$ & .19 & .09 \\
\hline \multirow[t]{7}{*}{3} & 05422000 & Wapsipinicon River near DeWitt & 03/17/04 & 0830 & $<.025$ & .08 & .05 \\
\hline & & & $04 / 15 / 04$ & 0830 & $<.025$ & .12 & .05 \\
\hline & & & 05/18/04 & 1200 & $<.025$ & .18 & .16 \\
\hline & & & $05 / 25 / 04$ & 1430 & $<.025$ & .58 & .37 \\
\hline & & & 06/16/04 & 1230 & $<.025$ & .25 & .15 \\
\hline & & & 07/20/04 & 1200 & $<.025$ & $<.025$ & $<.025$ \\
\hline & & & 09/14/04 & 0730 & $<.025$ & .10 & .13 \\
\hline \multirow[t]{5}{*}{4} & 05474000 & Skunk River at Augusta & 03/17/04 & 1430 & $<.025$ & .07 & .05 \\
\hline & & & $04 / 15 / 04$ & 1345 & $<.025$ & .11 & .06 \\
\hline & & & 05/18/04 & 0730 & $<.025$ & .15 & .10 \\
\hline & & & 06/16/04 & 0900 & $<.025$ & .58 & .30 \\
\hline & & & $07 / 20 / 04$ & 0800 & $<.025$ & .36 & $<.025$ \\
\hline & & & 09/13/04 & 1530 & $<.025$ & .12 & .19 \\
\hline
\end{tabular}


Table 9. Concentrations of triazine and phenylurea herbicides and their degradation products analyzed by the U.S. Geological Survey Organic Geochemistry Research Laboratory, Lawrence, Kansas, for water samples collected from 10 rivers in lowa, 2004.-Continued

$[<$, less than; --, no data]

\begin{tabular}{|c|c|c|c|c|c|c|c|}
\hline \multirow[b]{2}{*}{$\begin{array}{c}\text { Map } \\
\text { number } \\
\text { (fig. 4) }\end{array}$} & \multirow{2}{*}{$\begin{array}{l}\text { U.S. Geo- } \\
\text { logical } \\
\text { Survey site } \\
\text { identifica- } \\
\text { tion number }\end{array}$} & \multirow[b]{2}{*}{ Site name } & \multirow[b]{2}{*}{$\begin{array}{c}\text { Date of } \\
\text { collection } \\
\text { (month/day/ } \\
\text { year) }\end{array}$} & \multirow[b]{2}{*}{$\begin{array}{l}\text { Collection } \\
\text { time } \\
\text { (24-hour) }\end{array}$} & \multicolumn{3}{|c|}{ Concentration, in micrograms per liter } \\
\hline & & & & & $\begin{array}{l}\text { Deiso- } \\
\text { propyl- } \\
\text { hydroxy- } \\
\text { atrazine }\end{array}$ & $\begin{array}{l}\text { Didealkyl- } \\
\text { atrazine }\end{array}$ & $\begin{array}{l}\text { Hydroxy- } \\
\text { atrazine }\end{array}$ \\
\hline \multirow[t]{6}{*}{5} & 05490500 & Des Moines River at Keosauqua & 03/18/04 & 1230 & $<0.025$ & 0.05 & 0.10 \\
\hline & & & $04 / 22 / 04$ & 0910 & $<.025$ & .07 & .06 \\
\hline & & & 05/17/04 & 1400 & $<.025$ & .10 & .10 \\
\hline & & & $06 / 14 / 04$ & 1400 & $<.025$ & .23 & .25 \\
\hline & & & 07/19/04 & 1600 & $<.025$ & .32 & $<.025$ \\
\hline & & & 09/13/04 & 1330 & $<.025$ & .11 & .24 \\
\hline \multirow[t]{6}{*}{6} & 06485500 & Big Sioux River at Akron & 03/09/04 & 1200 & $<.025$ & $<.025$ & .26 \\
\hline & & & 04/13/04 & 0930 & $<.025$ & .09 & .05 \\
\hline & & & 05/12/04 & 1030 & $<.025$ & .14 & .06 \\
\hline & & & 05/26/04 & 1300 & $<.025$ & .32 & .16 \\
\hline & & & 06/02/04 & 1215 & $<.025$ & .29 & .40 \\
\hline & & & 07/14/04 & 1030 & $<.025$ & .26 & .15 \\
\hline \multirow[t]{7}{*}{7} & 06607500 & Little Sioux River near Turin & 03/10/04 & 0830 & $<.025$ & .06 & .18 \\
\hline & & & 04/13/04 & 1400 & $<.025$ & .11 & .05 \\
\hline & & & 05/11/04 & 1020 & $<.025$ & .14 & .63 \\
\hline & & & 05/24/04 & 1100 & $<.025$ & .37 & .96 \\
\hline & & & 06/08/04 & 0850 & $<.025$ & .19 & .12 \\
\hline & & & $06 / 17 / 04$ & 1230 & .06 & .25 & .86 \\
\hline & & & 07/13/04 & 1000 & $<.025$ & .27 & $<.025$ \\
\hline \multirow[t]{7}{*}{8} & 06609500 & Boyer River at Logan & $03 / 12 / 04$ & 0930 & $<.025$ & .08 & .07 \\
\hline & & & $04 / 14 / 04$ & 0730 & $<.025$ & .12 & .07 \\
\hline & & & 05/11/04 & 1300 & $<.025$ & .15 & .09 \\
\hline & & & $05 / 23 / 04$ & 1015 & $<.025$ & .73 & 1.0 \\
\hline & & & 06/08/04 & 1130 & $<.025$ & .24 & .15 \\
\hline & & & $06 / 17 / 04$ & 1000 & .08 & .55 & 1.5 \\
\hline & & & 07/13/04 & 1230 & $<.025$ & $<.025$ & .14 \\
\hline \multirow[t]{2}{*}{9} & 06810000 & Nishnabotna River above Hamburg & $03 / 11 / 04$ & 1030 & $<.025$ & .08 & .08 \\
\hline & & & 03/29/04 & 1230 & $<.025$ & .12 & .15 \\
\hline
\end{tabular}


Table 9. Concentrations of triazine and phenylurea herbicides and their degradation products analyzed by the U.S. Geological Survey Organic Geochemistry Research Laboratory, Lawrence, Kansas, for water samples collected from 10 rivers in lowa, 2004.-Continued

$[<$, less than; --, no data]

\begin{tabular}{|c|c|c|c|c|c|c|c|}
\hline \multirow[b]{2}{*}{$\begin{array}{c}\text { Map } \\
\text { number } \\
\text { (fig. 4) }\end{array}$} & \multirow{2}{*}{$\begin{array}{l}\text { U.S. Geo- } \\
\text { logical } \\
\text { Survey site } \\
\text { identifica- } \\
\text { tion number }\end{array}$} & \multirow[b]{2}{*}{ Site name } & \multirow[b]{2}{*}{$\begin{array}{c}\text { Date of } \\
\text { collection } \\
\text { (month/day/ } \\
\text { year) }\end{array}$} & \multirow[b]{2}{*}{$\begin{array}{l}\text { Collection } \\
\text { time } \\
\text { (24-hour) }\end{array}$} & \multicolumn{3}{|c|}{ Concentration, in micrograms per liter } \\
\hline & & & & & $\begin{array}{l}\text { Deiso- } \\
\text { propyl- } \\
\text { hydroxy- } \\
\text { atrazine }\end{array}$ & $\begin{array}{l}\text { Didealkyl- } \\
\text { atrazine }\end{array}$ & $\begin{array}{c}\text { Hydroxy- } \\
\text { atrazine }\end{array}$ \\
\hline \multirow[t]{5}{*}{9} & 06810000 & Nishnabotna River above Hamburg & $04 / 12 / 04$ & 1300 & $<0.025$ & 0.15 & 0.07 \\
\hline & & & 05/10/04 & 1230 & $<.025$ & .22 & .69 \\
\hline & & & $05 / 25 / 04$ & 1045 & $<.025$ & .84 & .84 \\
\hline & & & 06/07/04 & 1245 & $<.025$ & .31 & .16 \\
\hline & & & $07 / 12 / 04$ & 1230 & $<.025$ & .50 & .31 \\
\hline \multirow[t]{6}{*}{10} & 06904010 & Chariton River near Moulton & 03/18/04 & 0900 & $<.025$ & .08 & .44 \\
\hline & & & $04 / 22 / 04$ & 1320 & $<.025$ & .07 & .31 \\
\hline & & & $05 / 17 / 04$ & 1100 & $<.025$ & .07 & .33 \\
\hline & & & $06 / 14 / 04$ & 1050 & $<.025$ & .28 & .46 \\
\hline & & & $07 / 19 / 04$ & 1230 & $<.025$ & $<.025$ & $<.025$ \\
\hline & & & $09 / 13 / 04$ & 1030 & $<.025$ & .16 & .57 \\
\hline
\end{tabular}


Table 9. Concentrations of triazine and phenylurea herbicides and their degradation products analyzed by the U.S. Geological Survey Organic Geochemistry Research Laboratory, Lawrence, Kansas, for water samples collected from 10 rivers in lowa, 2004.-Continued

$[<$, less than; --, no data $]$

\begin{tabular}{|c|c|c|c|c|c|c|c|c|c|c|}
\hline \multirow[b]{2}{*}{$\begin{array}{l}\text { Map } \\
\text { num- } \\
\text { ber } \\
\text { (fig. 4) }\end{array}$} & \multirow[b]{2}{*}{$\begin{array}{l}\text { U.S. Geo- } \\
\text { Iogical } \\
\text { Survey site } \\
\text { identifica- } \\
\text { tion number }\end{array}$} & \multirow[b]{2}{*}{ Site name } & \multirow{2}{*}{$\begin{array}{c}\text { Date of } \\
\text { collection } \\
\text { (month/ } \\
\text { day/ } \\
\text { year) }\end{array}$} & \multirow[b]{2}{*}{$\begin{array}{l}\text { Collec- } \\
\text { tion } \\
\text { time } \\
\text { (24-hour) }\end{array}$} & \multicolumn{6}{|c|}{ Concentration, in micrograms per liter } \\
\hline & & & & & $\begin{array}{l}\text { Bro- } \\
\text { macil }\end{array}$ & $\begin{array}{l}\text { Cyana- } \\
\text { zine }\end{array}$ & $\begin{array}{l}\text { Cyana- } \\
\text { zine } \\
\text { amide }\end{array}$ & $\begin{array}{c}\text { Cyana- } \\
\text { zine } \\
\text { acid }\end{array}$ & $\begin{array}{c}\text { Deethyl- } \\
\text { cyana- } \\
\text { zine }\end{array}$ & $\begin{array}{l}\text { Deethyl- } \\
\text { cyana- } \\
\text { zine } \\
\text { acid }\end{array}$ \\
\hline \multirow[t]{5}{*}{1} & 05412500 & Turkey River at Garber & $03 / 15 / 04$ & 1100 & $<0.025$ & $<0.025$ & $<0.025$ & $<0.025$ & $<0.020$ & $<0.025$ \\
\hline & & & 04/20/04 & 0950 & $<.025$ & $<.025$ & $<.025$ & $<.025$ & $<.020$ & $<.025$ \\
\hline & & & $05 / 24 / 04$ & 1115 & $<.025$ & $<.025$ & $<.025$ & $<.025$ & $<.020$ & $<.025$ \\
\hline & & & $06 / 10 / 04$ & 1000 & $<.025$ & $<.025$ & $<.025$ & $<.025$ & $<.020$ & $<.025$ \\
\hline & & & $07 / 21 / 04$ & 1130 & $<.025$ & $<.025$ & $<.025$ & $<.025$ & $<.020$ & $<.025$ \\
\hline \multirow{7}{*}{2} & & Spragueville & $03 / 29 / 04$ & 1500 & $<.025$ & $<.025$ & $<.025$ & $<.025$ & $<.020$ & $<.025$ \\
\hline & & & $04 / 20 / 04$ & 1510 & $<.025$ & $<.025$ & $<.025$ & $<.025$ & $<.020$ & .08 \\
\hline & & & 05/19/04 & 0800 & $<.025$ & $<.025$ & $<.025$ & $<.025$ & $<.020$ & $<.025$ \\
\hline & & & $05 / 25 / 04$ & 1015 & $<.025$ & $<.025$ & $<.025$ & $<.025$ & $<.020$ & $<.025$ \\
\hline & & & 06/10/04 & 1300 & $<.025$ & $<.025$ & $<.025$ & $<.025$ & $<.020$ & $<.025$ \\
\hline & & & $07 / 21 / 04$ & 0720 & $<.025$ & $<.025$ & $<.025$ & $<.025$ & $<.020$ & $<.025$ \\
\hline & & & 09/14/04 & 1000 & $<.025$ & $<.025$ & $<.025$ & $<.025$ & $<.020$ & .06 \\
\hline \multirow{2}{*}{3} & & & 07/20/04 & 1200 & $<.025$ & $<.025$ & $<.025$ & $<.025$ & $<.020$ & $<.025$ \\
\hline & & & 09/14/04 & 0730 & $<.025$ & $<.025$ & $<.025$ & $<.025$ & $<.020$ & $<.025$ \\
\hline \multirow[t]{6}{*}{4} & 05474000 & Skunk River at Augusta & 03/17/04 & 1430 & $<.025$ & $<.025$ & $<.025$ & $<.025$ & $<.020$ & $<.025$ \\
\hline & & & $04 / 15 / 04$ & 1345 & $<.025$ & $<.025$ & $<.025$ & $<.025$ & $<.020$ & .08 \\
\hline & & & 05/18/04 & 0730 & $<.025$ & $<.025$ & $<.025$ & $<.025$ & $<.020$ & $<.025$ \\
\hline & & & 06/16/04 & 0900 & $<.025$ & $<.025$ & $<.025$ & $<.025$ & $<.020$ & $<.025$ \\
\hline & & & $07 / 20 / 04$ & 0800 & $<.025$ & $<.025$ & $<.025$ & $<.025$ & $<.020$ & $<.025$ \\
\hline & & & $09 / 13 / 04$ & 1530 & $<.025$ & $<.025$ & $<.025$ & $<.025$ & $<.020$ & $<.025$ \\
\hline
\end{tabular}


Table 9. Concentrations of triazine and phenylurea herbicides and their degradation products analyzed by the U.S. Geological Survey Organic Geochemistry Research Laboratory, Lawrence, Kansas, for water samples collected from 10 rivers in lowa, 2004.—Continued

$[<$, less than; --, no data $]$

\begin{tabular}{|c|c|c|c|c|c|c|c|c|c|c|}
\hline \multirow[b]{2}{*}{$\begin{array}{l}\text { Map } \\
\text { num- } \\
\text { ber } \\
\text { (fig. 4) }\end{array}$} & \multirow{2}{*}{$\begin{array}{l}\text { U.S. Geo- } \\
\text { logical } \\
\text { Survey site } \\
\text { identifica- } \\
\text { tion number }\end{array}$} & \multirow[b]{2}{*}{ Site name } & \multirow{2}{*}{$\begin{array}{c}\text { Date of } \\
\text { collection } \\
\text { (month/ } \\
\text { day/ } \\
\text { year) }\end{array}$} & \multirow[b]{2}{*}{$\begin{array}{c}\text { Collec- } \\
\text { tion } \\
\text { time } \\
\text { (24-hour) }\end{array}$} & \multicolumn{6}{|c|}{ Concentration, in micrograms per liter } \\
\hline & & & & & $\begin{array}{l}\text { Bro- } \\
\text { macil }\end{array}$ & $\begin{array}{l}\text { Cyana- } \\
\text { zine }\end{array}$ & $\begin{array}{l}\text { Cyana- } \\
\text { zine } \\
\text { amide }\end{array}$ & $\begin{array}{l}\text { Cyana- } \\
\text { zine } \\
\text { acid }\end{array}$ & $\begin{array}{c}\text { Deethyl- } \\
\text { cyana- } \\
\text { zine }\end{array}$ & $\begin{array}{l}\text { Deethyl- } \\
\text { cyana- } \\
\text { zine } \\
\text { acid }\end{array}$ \\
\hline \multirow[t]{6}{*}{5} & \multirow[t]{6}{*}{05490500} & \multirow{6}{*}{$\begin{array}{l}\text { Des Moines River at } \\
\text { Keosauqua }\end{array}$} & 03/18/04 & 1230 & $<0.025$ & $<0.025$ & $<0.025$ & $<0.025$ & $<0.020$ & $<0.025$ \\
\hline & & & $04 / 22 / 04$ & 0910 & $<.025$ & $<.025$ & $<.025$ & $<.025$ & $<.020$ & $<.025$ \\
\hline & & & 05/17/04 & 1400 & $<.025$ & $<.025$ & $<.025$ & $<.025$ & $<.020$ & $<.025$ \\
\hline & & & $06 / 14 / 04$ & 1400 & $<.025$ & $<.025$ & $<.025$ & $<.025$ & $<.020$ & $<.025$ \\
\hline & & & 07/19/04 & 1600 & $<.025$ & $<.025$ & $<.025$ & $<.025$ & $<.020$ & $<.025$ \\
\hline & & & 09/13/04 & 1330 & $<.025$ & $<.025$ & $<.025$ & $<.025$ & $<.020$ & $<.025$ \\
\hline \multirow[t]{6}{*}{6} & \multirow[t]{6}{*}{06485500} & \multirow[t]{6}{*}{ Big Sioux River at Akron } & 03/09/04 & 1200 & $<.025$ & $<.025$ & $<.025$ & $<.025$ & $<.020$ & $<.025$ \\
\hline & & & $04 / 13 / 04$ & 0930 & $<.025$ & $<.025$ & $<.025$ & $<.025$ & $<.020$ & .38 \\
\hline & & & $05 / 12 / 04$ & 1030 & $<.025$ & $<.025$ & $<.025$ & $<.025$ & $<.020$ & .41 \\
\hline & & & 05/26/04 & 1300 & $<.025$ & $<.025$ & $<.025$ & $<.025$ & $<.020$ & .25 \\
\hline & & & 06/02/04 & 1215 & $<.025$ & $<.025$ & $<.025$ & $<.025$ & $<.020$ & $<.025$ \\
\hline & & & 07/14/04 & 1030 & $<.025$ & $<.025$ & $<.025$ & $<.025$ & $<.020$ & $<.025$ \\
\hline \multirow[t]{7}{*}{7} & \multirow[t]{7}{*}{06607500} & \multirow{7}{*}{$\begin{array}{l}\text { Little Sioux River near } \\
\text { Turin }\end{array}$} & 03/10/04 & 0830 & $<.025$ & $<.025$ & $<.025$ & $<.025$ & $<.020$ & .21 \\
\hline & & & 04/13/04 & 1400 & $<.025$ & $<.025$ & $<.025$ & $<.025$ & $<.020$ & .58 \\
\hline & & & 05/11/04 & 1020 & $<.025$ & $<.025$ & $<.025$ & $<.025$ & $<.020$ & .41 \\
\hline & & & $05 / 24 / 04$ & 1100 & $<.025$ & $<.025$ & $<.025$ & $<.025$ & $<.020$ & .26 \\
\hline & & & 06/08/04 & 0850 & $<.025$ & $<.025$ & $<.025$ & $<.025$ & $<.020$ & .19 \\
\hline & & & 06/17/04 & 1230 & $<.025$ & $<.025$ & $<.025$ & $<.025$ & $<.020$ & .06 \\
\hline & & & 07/13/04 & 1000 & $<.025$ & $<.025$ & $<.025$ & $<.025$ & $<.020$ & $<.025$ \\
\hline \multirow[t]{7}{*}{8} & \multirow[t]{7}{*}{06609500} & \multirow[t]{7}{*}{ Boyer River at Logan } & 03/12/04 & 0930 & $<.025$ & $<.025$ & $<.025$ & $<.025$ & $<.020$ & .35 \\
\hline & & & $04 / 14 / 04$ & 0730 & $<.025$ & $<.025$ & $<.025$ & $<.025$ & $<.020$ & .71 \\
\hline & & & 05/11/04 & 1300 & $<.025$ & $<.025$ & $<.025$ & $<.025$ & $<.020$ & .80 \\
\hline & & & $05 / 23 / 04$ & 1015 & $<.025$ & $<.025$ & $<.025$ & $<.025$ & $<.020$ & 1.0 \\
\hline & & & 06/08/04 & 1130 & $<.025$ & $<.025$ & $<.025$ & $<.025$ & $<.020$ & .47 \\
\hline & & & $06 / 17 / 04$ & 1000 & $<.025$ & $<.025$ & $<.025$ & $<.025$ & $<.020$ & $<.025$ \\
\hline & & & 07/13/04 & 1230 & $<.025$ & $<.025$ & $<.025$ & $<.025$ & $<.020$ & .23 \\
\hline \multirow[t]{3}{*}{9} & \multirow[t]{3}{*}{06810000} & \multirow{3}{*}{$\begin{array}{l}\text { Nishnabotna River above } \\
\text { Hamburg }\end{array}$} & 03/11/04 & 1030 & $<.025$ & $<.025$ & $<.025$ & $<.025$ & $<.020$ & .20 \\
\hline & & & 03/29/04 & 1230 & $<.025$ & $<.025$ & $<.025$ & $<.025$ & $<.020$ & .26 \\
\hline & & & 04/12/04 & 1300 & $<.025$ & $<.025$ & $<.025$ & $<.025$ & $<.020$ & .55 \\
\hline
\end{tabular}


Table 9. Concentrations of triazine and phenylurea herbicides and their degradation products analyzed by the U.S. Geological Survey Organic Geochemistry Research Laboratory, Lawrence, Kansas, for water samples collected from 10 rivers in lowa, 2004.-Continued

[<, less than; --, no data]

\begin{tabular}{|c|c|c|c|c|c|c|c|c|c|c|}
\hline $\begin{array}{l}\text { Map } \\
\text { num- } \\
\text { ber } \\
\text { (fig. 4) }\end{array}$ & $\begin{array}{l}\text { U.S. Geo- } \\
\text { logical } \\
\text { Survey site } \\
\text { identifica- } \\
\text { tion number }\end{array}$ & Site name & $\begin{array}{c}\text { Date of } \\
\text { collection } \\
\text { (month/ } \\
\text { day/ } \\
\text { year) }\end{array}$ & $\begin{array}{l}\text { Collec- } \\
\text { tion } \\
\text { time } \\
\text { (24-hour) }\end{array}$ & $\begin{array}{l}\text { Bro- } \\
\text { macil }\end{array}$ & $\begin{array}{l}\text { Cyana- } \\
\text { zine }\end{array}$ & $\begin{array}{c}\text { Cyana- } \\
\text { zine } \\
\text { amide }\end{array}$ & $\begin{array}{c}\text { Cyana- } \\
\text { zine } \\
\text { acid }\end{array}$ & $\begin{array}{c}\text { Deethyl- } \\
\text { cyana- } \\
\text { zine }\end{array}$ & $\begin{array}{l}\text { Deethyl- } \\
\text { cyana- } \\
\text { zine } \\
\text { acid }\end{array}$ \\
\hline \multirow[t]{3}{*}{9} & \multirow[t]{3}{*}{06810000} & \multirow{3}{*}{$\begin{array}{l}\text { Nishnabotna River above } \\
\text { Hamburg }\end{array}$} & 05/10/04 & 1230 & $<0.025$ & $<0.025$ & $<0.025$ & $<0.025$ & $<0.020$ & 0.27 \\
\hline & & & 06/07/04 & 1245 & $<.025$ & $<.025$ & $<.025$ & $<.025$ & $<.020$ & .33 \\
\hline & & & 07/12/04 & 1230 & $<.025$ & $<.025$ & $<.025$ & $<.025$ & $<.020$ & .43 \\
\hline \multirow[t]{4}{*}{10} & \multirow[t]{4}{*}{06904010} & \multirow{4}{*}{$\begin{array}{l}\text { Chariton River near } \\
\text { Moulton }\end{array}$} & 03/18/04 & 0900 & $<.025$ & $<.025$ & $<.025$ & $<.025$ & $<.020$ & $<.025$ \\
\hline & & & $04 / 22 / 04$ & 1320 & $<.025$ & $<.025$ & $<.025$ & $<.025$ & $<.020$ & $<.025$ \\
\hline & & & 07/19/04 & 1230 & $<.025$ & $<.025$ & $<.025$ & $<.025$ & $<.020$ & $<.025$ \\
\hline & & & 09/13/04 & 1030 & $<.025$ & $<.025$ & $<.025$ & $<.025$ & $<.020$ & $<.025$ \\
\hline
\end{tabular}


Table 9. Concentrations of triazine and phenylurea herbicides and their degradation products analyzed by the U.S. Geological Survey Organic Geochemistry Research Laboratory, Lawrence, Kansas, for water samples collected from 10 rivers in lowa, 2004.-Continued

$[<$, less than; --, no data $]$

\begin{tabular}{|c|c|c|c|c|c|c|c|c|c|}
\hline \multirow[b]{2}{*}{$\begin{array}{c}\text { Map } \\
\text { number } \\
\text { (fig. 4) }\end{array}$} & \multirow{2}{*}{$\begin{array}{l}\text { U.S. Geo- } \\
\text { logical } \\
\text { Survey site } \\
\text { identifica- } \\
\text { tion number }\end{array}$} & \multirow[b]{2}{*}{ Site name } & \multirow[b]{2}{*}{$\begin{array}{c}\text { Date of } \\
\text { collection } \\
\text { (month/day/ } \\
\text { year) }\end{array}$} & \multirow[b]{2}{*}{$\begin{array}{c}\text { Collection } \\
\text { time } \\
\text { (24-hour) }\end{array}$} & \multicolumn{5}{|c|}{ Concentration, in micrograms per liter } \\
\hline & & & & & $\begin{array}{l}\text { Deethyl- } \\
\text { cyana- } \\
\text { zine } \\
\text { amide }\end{array}$ & $\begin{array}{c}\text { Prome- } \\
\text { ton }\end{array}$ & $\begin{array}{c}\text { Propa- } \\
\text { zine }\end{array}$ & $\begin{array}{l}\text { Sima- } \\
\text { zine }\end{array}$ & $\begin{array}{l}\text { Hydroxy- } \\
\text { sima- } \\
\text { zine }\end{array}$ \\
\hline \multirow[t]{5}{*}{1} & 05412500 & Turkey River at Garber & 03/15/04 & 1100 & $<0.025$ & -- & $<0.025$ & $<0.025$ & $<0.025$ \\
\hline & & & 04/20/04 & 0950 & $<.025$ & -- & $<.025$ & $<.025$ & $<.025$ \\
\hline & & & $05 / 24 / 04$ & 1115 & $<.025$ & $<.025$ & $<.025$ & $<.025$ & $<.025$ \\
\hline & & & 06/10/04 & 1000 & $<.025$ & $<.025$ & $<.025$ & .03 & $<.025$ \\
\hline & & & $07 / 21 / 04$ & 1130 & $<.025$ & $<.025$ & $<.025$ & $<.025$ & $<.025$ \\
\hline \multirow{6}{*}{2} & & Spragueville & $03 / 29 / 04$ & 1500 & $<.025$ & -- & $<.025$ & $<.025$ & $<.025$ \\
\hline & & & 04/20/04 & 1510 & $<.025$ & -- & $<.025$ & $<.025$ & $<.025$ \\
\hline & & & 05/19/04 & 0800 & $<.025$ & -- & $<.025$ & .04 & $<.025$ \\
\hline & & & 05/25/04 & 1015 & $<.025$ & $<.025$ & .04 & $<.025$ & $<.025$ \\
\hline & & & 06/10/04 & 1300 & $<.025$ & $<.025$ & $<.025$ & $<.025$ & $<.025$ \\
\hline & & & $07 / 21 / 04$ & 0720 & $<.025$ & $<.025$ & $<.025$ & $<.025$ & $<.025$ \\
\hline \multirow{3}{*}{3} & & & 06/16/04 & 1230 & $<.025$ & $<.025$ & $<.025$ & $<.025$ & $<.025$ \\
\hline & & & 07/20/04 & 1200 & $<.025$ & $<.025$ & $<.025$ & $<.025$ & $<.025$ \\
\hline & & & 09/14/04 & 0730 & $<.025$ & $<.025$ & $<.025$ & $<.025$ & $<.025$ \\
\hline \multirow[t]{6}{*}{4} & 05474000 & Skunk River at Augusta & 03/17/04 & 1430 & $<.025$ & -- & $<.025$ & $<.025$ & $<.025$ \\
\hline & & & $04 / 15 / 04$ & 1345 & $<.025$ & -- & $<.025$ & $<.025$ & $<.025$ \\
\hline & & & 05/18/04 & 0730 & $<.025$ & -- & $<.025$ & $<.025$ & $<.025$ \\
\hline & & & 06/16/04 & 0900 & $<.025$ & $<.025$ & .03 & $<.025$ & $<.025$ \\
\hline & & & 07/20/04 & 0800 & $<.025$ & $<.025$ & $<.025$ & $<.025$ & $<.025$ \\
\hline & & & 09/13/04 & 1530 & $<.025$ & $<.025$ & $<.025$ & $<.025$ & $<.025$ \\
\hline
\end{tabular}


Table 9. Concentrations of triazine and phenylurea herbicides and their degradation products analyzed by the U.S. Geological Survey Organic Geochemistry Research Laboratory, Lawrence, Kansas, for water samples collected from 10 rivers in lowa, 2004. - Continued

$[<$, less than; --, no data $]$

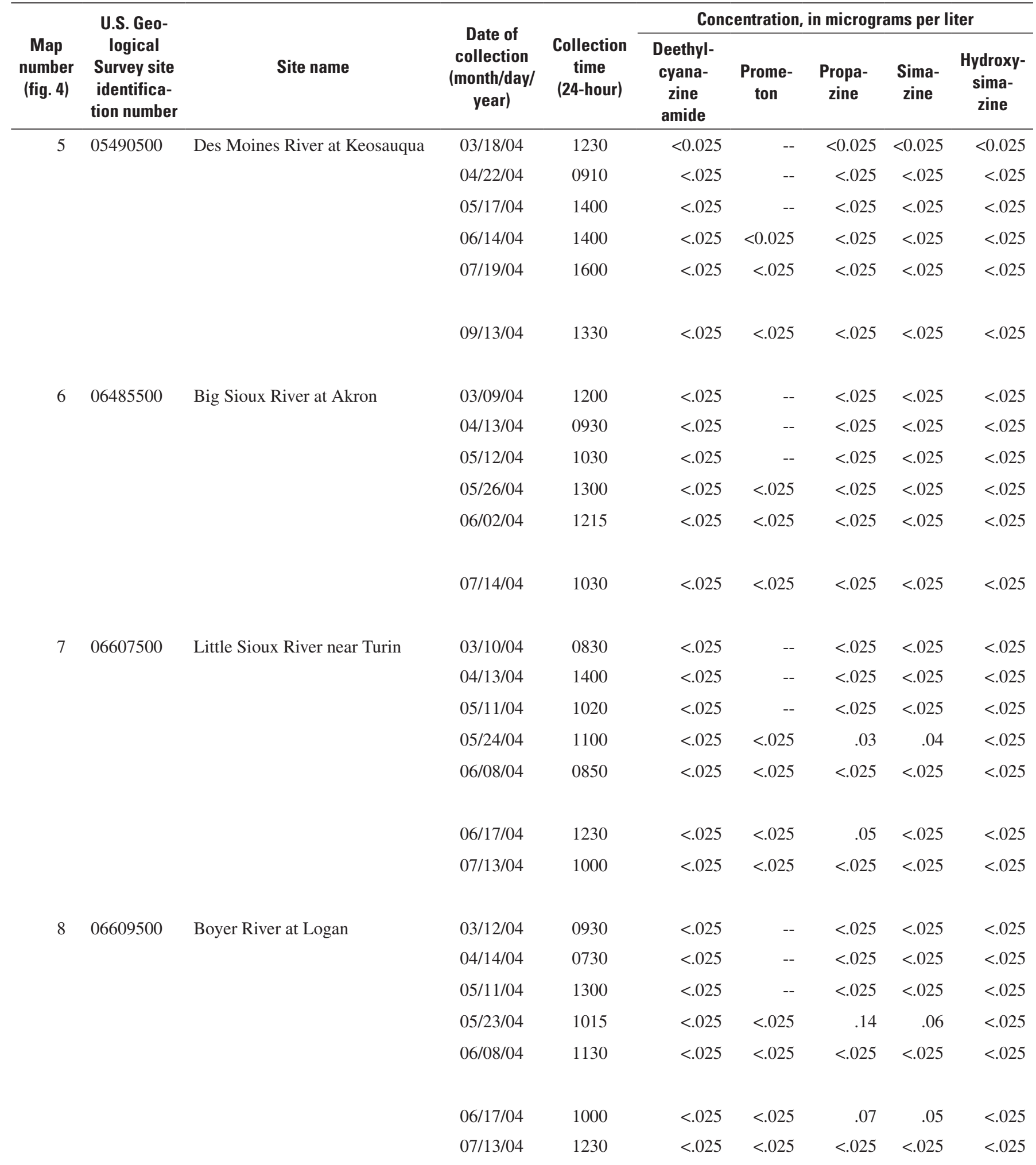


Table 9. Concentrations of triazine and phenylurea herbicides and their degradation products analyzed by the U.S. Geological Survey Organic Geochemistry Research Laboratory, Lawrence, Kansas, for water samples collected from 10 rivers in lowa, 2004.-Continued

$[<$, less than; --, no data]

\begin{tabular}{|c|c|c|c|c|c|c|c|c|c|}
\hline \multirow[b]{2}{*}{$\begin{array}{c}\text { Map } \\
\text { number } \\
\text { (fig. 4) }\end{array}$} & \multirow{2}{*}{$\begin{array}{l}\text { U.S. Geo- } \\
\text { logical } \\
\text { Survey site } \\
\text { identifica- } \\
\text { tion number }\end{array}$} & \multirow[b]{2}{*}{ Site name } & \multirow[b]{2}{*}{$\begin{array}{c}\text { Date of } \\
\text { collection } \\
\text { (month/day/ } \\
\text { year) }\end{array}$} & \multirow[b]{2}{*}{$\begin{array}{c}\text { Collection } \\
\text { time } \\
\text { (24-hour) }\end{array}$} & \multicolumn{5}{|c|}{ Concentration, in micrograms per liter } \\
\hline & & & & & $\begin{array}{l}\text { Deethyl- } \\
\text { cyana- } \\
\text { zine } \\
\text { amide }\end{array}$ & $\begin{array}{c}\text { Prome- } \\
\text { ton }\end{array}$ & $\begin{array}{c}\text { Propa- } \\
\text { zine }\end{array}$ & $\begin{array}{l}\text { Sima- } \\
\text { zine }\end{array}$ & $\begin{array}{l}\text { Hydroxy- } \\
\text { sima- } \\
\text { zine }\end{array}$ \\
\hline \multirow[t]{5}{*}{9} & 06810000 & Nishnabotna River above & 03/11/04 & 1030 & $<0.025$ & -- & $<0.025$ & $<0.025$ & $<0.025$ \\
\hline & & Hamburg & 03/29/04 & 1230 & $<.025$ & -- & $<.025$ & $<.025$ & $<.025$ \\
\hline & & & 05/10/04 & 1230 & $<.025$ & $<0.025$ & .21 & .08 & $<.025$ \\
\hline & & & $05 / 25 / 04$ & 1045 & $<.025$ & $<.025$ & .06 & .02 & $<.025$ \\
\hline & & & 06/07/04 & 1245 & $<.025$ & $<.025$ & $<.025$ & $<.025$ & $<.025$ \\
\hline \multirow{5}{*}{10} & & & $04 / 22 / 04$ & 1320 & $<.025$ & -- & $<.025$ & .03 & $<.025$ \\
\hline & & & 05/17/04 & 1100 & $<.025$ & -- & $<.025$ & $<.025$ & $<.025$ \\
\hline & & & $06 / 14 / 04$ & 1050 & $<.025$ & $<.025$ & $<.025$ & .03 & $<.025$ \\
\hline & & & 07/19/04 & 1230 & $<.025$ & $<.025$ & $<.025$ & .05 & $<.025$ \\
\hline & & & 09/13/04 & 1030 & $<.025$ & $<.025$ & $<.025$ & $<.025$ & $<.025$ \\
\hline
\end{tabular}


Table 9. Concentrations of triazine and phenylurea herbicides and their degradation products analyzed by the U.S. Geological Survey Organic Geochemistry Research Laboratory, Lawrence, Kansas, for water samples collected from 10 rivers in lowa, 2004.-Continued

$[<$, less than; --, no data $]$

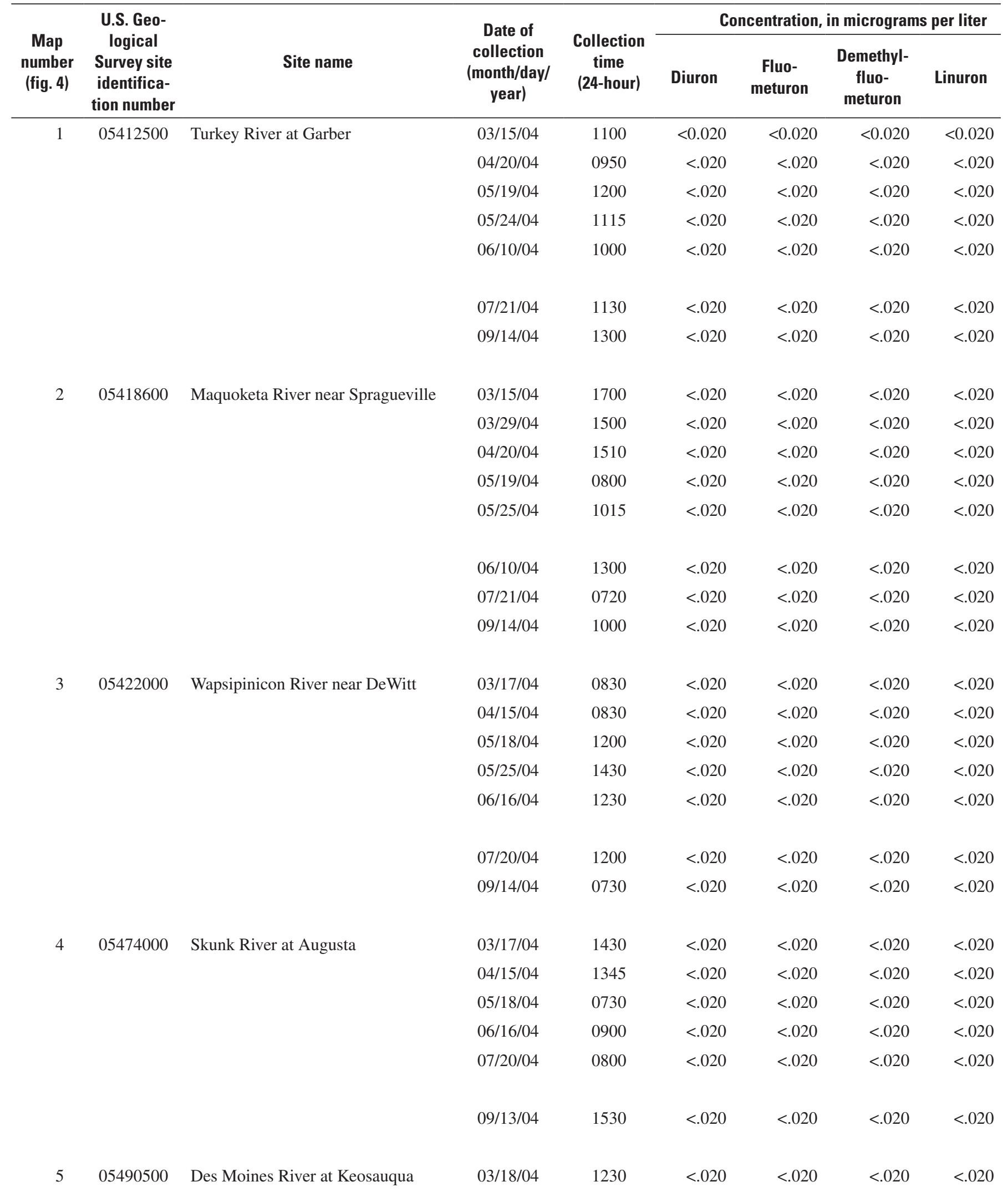


Table 9. Concentrations of triazine and phenylurea herbicides and their degradation products analyzed by the U.S. Geological Survey Organic Geochemistry Research Laboratory, Lawrence, Kansas, for water samples collected from 10 rivers in lowa, 2004.-Continued

$[<$, less than; --, no data]

\begin{tabular}{|c|c|c|c|c|c|c|c|c|}
\hline \multirow[b]{2}{*}{$\begin{array}{c}\text { Map } \\
\text { number } \\
\text { (fig. 4) }\end{array}$} & \multirow{2}{*}{$\begin{array}{l}\text { U.S. Geo- } \\
\text { logical } \\
\text { Survey site } \\
\text { identifica- } \\
\text { tion number }\end{array}$} & \multirow[b]{2}{*}{ Site name } & \multirow{2}{*}{$\begin{array}{c}\text { Date of } \\
\text { collection } \\
\text { (month/day/ } \\
\text { year) }\end{array}$} & \multirow[b]{2}{*}{$\begin{array}{c}\text { Collection } \\
\text { time } \\
\text { (24-hour) }\end{array}$} & \multicolumn{4}{|c|}{ Concentration, in micrograms per liter } \\
\hline & & & & & Diuron & $\begin{array}{c}\text { Fluo- } \\
\text { meturon }\end{array}$ & $\begin{array}{c}\text { Demethyl- } \\
\text { fluo- } \\
\text { meturon }\end{array}$ & Linuron \\
\hline \multirow[t]{4}{*}{5} & 05490500 & Des Moines River at Keosauqua & $04 / 22 / 04$ & 0910 & $<0.020$ & $<0.020$ & $<0.020$ & $<0.020$ \\
\hline & & & 05/17/04 & 1400 & $<.020$ & $<.020$ & $<.020$ & $<.020$ \\
\hline & & & 07/19/04 & 1600 & $<.020$ & $<.020$ & $<.020$ & $<.020$ \\
\hline & & & 09/13/04 & 1330 & $<.020$ & $<.020$ & $<.020$ & $<.020$ \\
\hline \multirow[t]{3}{*}{6} & 06485500 & Big Sioux River at Akron & 03/09/04 & 1200 & $<.020$ & $<.020$ & $<.020$ & $<.020$ \\
\hline & & & 06/02/04 & 1215 & $<.020$ & $<.020$ & $<.020$ & $<.020$ \\
\hline & & & 07/14/04 & 1030 & $<.020$ & $<.020$ & $<.020$ & $<.020$ \\
\hline \multirow[t]{4}{*}{7} & 06607500 & Little Sioux River near Turin & 03/10/04 & 0830 & $<.020$ & $<.020$ & $<.020$ & $<.020$ \\
\hline & & & 04/13/04 & 1400 & $<.020$ & $<.020$ & $<.020$ & $<.020$ \\
\hline & & & 05/11/04 & 1020 & $<.020$ & $<.020$ & $<.020$ & $<.020$ \\
\hline & & & 05/24/04 & 1100 & $<.020$ & $<.020$ & $<.020$ & $<.020$ \\
\hline \multirow{6}{*}{8} & & & $04 / 14 / 04$ & 0730 & $<.020$ & $<.020$ & $<.020$ & $<.020$ \\
\hline & & & 05/11/04 & 1300 & $<.020$ & $<.020$ & $<.020$ & $<.020$ \\
\hline & & & $05 / 23 / 04$ & 1015 & $<.020$ & $<.020$ & $<.020$ & $<.020$ \\
\hline & & & 06/08/04 & 1130 & $<.020$ & $<.020$ & $<.020$ & $<.020$ \\
\hline & & & 06/17/04 & 1000 & $<.020$ & $<.020$ & $<.020$ & $<.020$ \\
\hline & & & 07/13/04 & 1230 & $<.020$ & $<.020$ & $<.020$ & $<.020$ \\
\hline \multirow[t]{5}{*}{9} & 06810000 & Nishnabotna River above Hamburg & 03/11/04 & 1030 & $<.020$ & $<.020$ & $<.020$ & $<.020$ \\
\hline & & & $03 / 29 / 04$ & 1230 & $<.020$ & $<.020$ & $<.020$ & $<.020$ \\
\hline & & & $04 / 12 / 04$ & 1300 & $<.020$ & $<.020$ & $<.020$ & $<.020$ \\
\hline & & & 05/10/04 & 1230 & $<.020$ & $<.020$ & $<.020$ & $<.020$ \\
\hline & & & $05 / 25 / 04$ & 1045 & $<.020$ & $<.020$ & $<.020$ & $<.020$ \\
\hline
\end{tabular}


Table 9. Concentrations of triazine and phenylurea herbicides and their degradation products analyzed by the U.S. Geological Survey Organic Geochemistry Research Laboratory, Lawrence, Kansas, for water samples collected from 10 rivers in lowa, 2004.-Continued

$[<$, less than; --, no data]

\begin{tabular}{|c|c|c|c|c|c|c|c|c|}
\hline \multirow[b]{2}{*}{$\begin{array}{c}\text { Map } \\
\text { number } \\
\text { (fig. 4) }\end{array}$} & \multirow{2}{*}{$\begin{array}{l}\text { U.S. Geo- } \\
\text { logical } \\
\text { Survey site } \\
\text { identifica- } \\
\text { tion number }\end{array}$} & \multirow[b]{2}{*}{ Site name } & \multirow[b]{2}{*}{$\begin{array}{c}\text { Date of } \\
\text { collection } \\
\text { (month/day/ } \\
\text { year) }\end{array}$} & \multirow[b]{2}{*}{$\begin{array}{l}\text { Collection } \\
\text { time } \\
\text { (24-hour) }\end{array}$} & \multicolumn{4}{|c|}{ Concentration, in micrograms per liter } \\
\hline & & & & & Diuron & $\begin{array}{c}\text { Fluo- } \\
\text { meturon }\end{array}$ & $\begin{array}{l}\text { Demethyl- } \\
\text { fluo- } \\
\text { meturon }\end{array}$ & Linuron \\
\hline \multirow[t]{2}{*}{9} & 06810000 & Nishnabotna River above Hamburg & 06/07/04 & 1245 & $<0.020$ & $<0.020$ & $<0.020$ & $<0.020$ \\
\hline & & & $07 / 12 / 04$ & 1230 & $<.020$ & $<.020$ & $<.020$ & $<.020$ \\
\hline \multirow[t]{4}{*}{10} & 06904010 & Chariton River near Moulton & 03/18/04 & 0900 & $<.020$ & $<.020$ & $<.020$ & $<.020$ \\
\hline & & & $04 / 22 / 04$ & 1320 & .38 & $<.020$ & $<.020$ & $<.020$ \\
\hline & & & $05 / 17 / 04$ & 1100 & $<.020$ & $<.020$ & $<.020$ & $<.020$ \\
\hline & & & $06 / 14 / 04$ & 1050 & $<.020$ & $<.020$ & $<.020$ & $<.020$ \\
\hline
\end{tabular}


Table 10. Concentrations of selected pesticides and pesticide degradation products determined by the U.S. Geological Survey National Water-Quality Laboratory, Lakewood, Colorado, using laboratory schedule 2001 for water samples collected from 10 rivers in lowa, 2004.

[E, estimated; EPTC, s-ethyl dipropylthiocarbamate; <, less than; --, not detected]

\begin{tabular}{|c|c|c|c|c|c|c|c|c|c|c|}
\hline \multirow{2}{*}{$\begin{array}{c}\text { Map } \\
\text { number } \\
\text { (fig. 4) }\end{array}$} & \multirow{2}{*}{$\begin{array}{l}\text { U.S. Geo- } \\
\text { logical } \\
\text { Survey site } \\
\text { identifica- } \\
\text { tion number }\end{array}$} & \multirow[b]{2}{*}{ Site name } & \multirow{2}{*}{$\begin{array}{c}\text { Date of } \\
\text { collection } \\
\text { (month/ } \\
\text { day/ } \\
\text { year) }\end{array}$} & \multirow{2}{*}{$\begin{array}{c}\text { Collec- } \\
\text { tion } \\
\text { time } \\
\text { (24-hour) }\end{array}$} & \multicolumn{6}{|c|}{ Concentrations, in micrograms per liter } \\
\hline & & & & & $\begin{array}{c}\text { Aceto- } \\
\text { chlor }\end{array}$ & $\begin{array}{l}\text { Ala- } \\
\text { chlor }\end{array}$ & $\begin{array}{l}\text { Atra- } \\
\text { zine }\end{array}$ & $\begin{array}{c}\text { Carb- } \\
\text { aryl }\end{array}$ & $\begin{array}{l}\text { Carbo- } \\
\text { furan }\end{array}$ & $\begin{array}{l}\text { Chloro- } \\
\text { pyrifos }\end{array}$ \\
\hline \multirow[t]{11}{*}{1} & 05412500 & Turkey River at Garber & 03/15/04 & 1100 & 0.038 & $<0.007$ & 0.104 & $<0.041$ & $<0.020$ & $<0.005$ \\
\hline & & & 04/20/04 & 0950 & .029 & $<.005$ & .125 & $<.041$ & $<.020$ & $<.005$ \\
\hline & & & 05/19/04 & 1200 & 2.5 & .014 & 5.6 & $<.041$ & $<.020$ & $<.005$ \\
\hline & & & 05/24/04 & 1100 & 4.9 & .147 & 7.1 & $<.041$ & $<.020$ & .009 \\
\hline & & & 06/10/04 & 1000 & .336 & .008 & 1.9 & $<.041$ & E.016 & .037 \\
\hline & & & 07/21/04 & 1130 & .019 & $<.005$ & .264 & $<.041$ & $<.020$ & $<.005$ \\
\hline & & & 08/17/04 & 1445 & .016 & $<.005$ & .189 & $<.041$ & $<.020$ & $<.005$ \\
\hline & & & 09/14/04 & 1300 & .008 & $<.005$ & .147 & $<.041$ & $<.020$ & $<.005$ \\
\hline & & & $10 / 18 / 04$ & 1030 & E.005 & $<.005$ & .112 & $<.041$ & $<.020$ & $<.005$ \\
\hline & & & $11 / 16 / 04$ & 0901 & $<.006$ & $<.005$ & .093 & $<.041$ & $<.020$ & $<.005$ \\
\hline & & & $12 / 06 / 04$ & 0955 & $<.006$ & $<.005$ & .073 & $<.041$ & $<.020$ & $<.005$ \\
\hline \multirow[t]{12}{*}{2} & 05418600 & Maquoketa River near & 03/15/04 & 1700 & .009 & .006 & .074 & $<.041$ & $<.020$ & $<.005$ \\
\hline & & Spragueville & 03/29/04 & 1500 & .015 & .008 & .090 & $<.041$ & $<.020$ & $<.005$ \\
\hline & & & $04 / 20 / 04$ & 1510 & .052 & $<.005$ & .154 & $<.041$ & $<.020$ & $<.005$ \\
\hline & & & 05/19/04 & 0800 & .526 & .007 & 1.5 & $<.041$ & $<.020$ & .006 \\
\hline & & & $05 / 25 / 04$ & 1000 & 5.5 & .080 & 10 & $<.041$ & E.092 & .013 \\
\hline & & & 06/10/04 & 1300 & .075 & E.005 & .571 & $<.041$ & E.006 & E.004 \\
\hline & & & $07 / 21 / 04$ & 0720 & .017 & $<.005$ & .238 & $<.041$ & $<.020$ & $<.005$ \\
\hline & & & 08/17/04 & 1025 & .009 & $<.005$ & .135 & $<.041$ & $<.020$ & $<.005$ \\
\hline & & & 09/14/04 & 1000 & $<.010$ & $<.005$ & .095 & $<.041$ & $<.020$ & $<.005$ \\
\hline & & & $10 / 18 / 04$ & 1330 & E.005 & $<.005$ & .096 & $<.041$ & $<.020$ & $<.005$ \\
\hline & & & $11 / 17 / 04$ & 0710 & $<.006$ & $<.005$ & .091 & $<.041$ & $<.020$ & $<.005$ \\
\hline & & & $12 / 06 / 04$ & 1340 & .047 & $<.010$ & .099 & $<.041$ & $<.020$ & $<.005$ \\
\hline \multirow[t]{5}{*}{3} & 05422000 & Wapsipinicon River near & 03/17/04 & 0830 & .023 & .007 & .078 & $<.041$ & $<.020$ & $<.005$ \\
\hline & & DeWitt & $04 / 15 / 04$ & 0830 & .012 & $<.005$ & .069 & $<.041$ & $<.020$ & $<.005$ \\
\hline & & & 05/18/04 & 1200 & 3.4 & .019 & 9.5 & $<.041$ & $<.020$ & E.008 \\
\hline & & & $05 / 25 / 04$ & 1400 & 3.2 & .149 & 8.6 & $<.041$ & E.026 & .010 \\
\hline & & & 06/16/04 & 1230 & .219 & .007 & 2.5 & $<.041$ & E.516 & $<.005$ \\
\hline & & & 07/20/04 & 1200 & .029 & $<.005$ & .517 & $<.041$ & E.031 & $<.005$ \\
\hline
\end{tabular}


Table 10. Concentrations of selected pesticides and pesticide degradation products determined by the U.S. Geological Survey National Water-Quality Laboratory, Lakewood, Colorado, using laboratory schedule 2001 for water samples collected from 10 rivers in lowa, 2004.-Continued

[E, estimated; EPTC, s-ethyl dipropylthiocarbamate; <, less than; --, not detected]

\begin{tabular}{|c|c|c|c|c|c|c|c|c|c|c|}
\hline \multirow{2}{*}{$\begin{array}{c}\text { Map } \\
\text { number } \\
\text { (fig. 4) }\end{array}$} & \multirow{2}{*}{$\begin{array}{l}\text { U.S. Geo- } \\
\text { logical } \\
\text { Survey site } \\
\text { identifica- } \\
\text { tion number }\end{array}$} & \multirow[b]{2}{*}{ Site name } & \multirow{2}{*}{$\begin{array}{l}\text { Date of } \\
\text { collection } \\
\text { (month/ } \\
\text { day/ } \\
\text { year) }\end{array}$} & \multirow{2}{*}{$\begin{array}{l}\text { Collec- } \\
\text { tion } \\
\text { time } \\
\text { (24-hour) }\end{array}$} & \multicolumn{6}{|c|}{ Concentrations, in micrograms per liter } \\
\hline & & & & & $\begin{array}{l}\text { Aceto- } \\
\text { chlor }\end{array}$ & $\begin{array}{l}\text { Ala- } \\
\text { chlor }\end{array}$ & $\begin{array}{l}\text { Atra- } \\
\text { zine }\end{array}$ & $\begin{array}{l}\text { Carb- } \\
\text { aryl }\end{array}$ & $\begin{array}{l}\text { Carbo- } \\
\text { furan }\end{array}$ & $\begin{array}{l}\text { Chloro- } \\
\text { pyrifos }\end{array}$ \\
\hline \multirow[t]{5}{*}{3} & \multirow[t]{5}{*}{05422000} & \multirow{5}{*}{$\begin{array}{l}\text { Wapsipinicon River near } \\
\text { DeWitt }\end{array}$} & 08/17/04 & 0745 & 0.015 & $<0.005$ & 0.247 & $<0.041$ & $<0.020$ & $<0.005$ \\
\hline & & & 09/14/04 & 0730 & .011 & $<.005$ & .173 & $<.041$ & $<.020$ & $<.005$ \\
\hline & & & 10/18/04 & 1520 & .006 & $<.005$ & .119 & $<.041$ & $<.020$ & $<.005$ \\
\hline & & & $11 / 17 / 04$ & 0845 & $<.010$ & $<.005$ & .100 & $<.041$ & $<.020$ & $<.005$ \\
\hline & & & $12 / 06 / 04$ & 1615 & .010 & $<.005$ & .062 & $<.041$ & $<.020$ & $<.005$ \\
\hline \multirow[t]{10}{*}{4} & \multirow[t]{10}{*}{05474000} & \multirow[t]{10}{*}{ Skunk River at Augusta } & 03/17/04 & 1430 & .019 & $<.005$ & .099 & $<.041$ & $<.020$ & $<.005$ \\
\hline & & & $04 / 15 / 04$ & 1345 & .013 & $<.005$ & .093 & $<.041$ & $<.020$ & $<.005$ \\
\hline & & & 05/18/04 & 0730 & .549 & .006 & 2.6 & $<.041$ & $<.020$ & $<.010$ \\
\hline & & & 06/16/04 & 0900 & .279 & .011 & 2.5 & $<.041$ & $<.020$ & $<.005$ \\
\hline & & & 07/20/04 & 0800 & .021 & $<.005$ & .363 & $<.041$ & $<.020$ & $<.005$ \\
\hline & & & 08/16/04 & 1615 & .017 & $<.005$ & .244 & $<.041$ & $<.020$ & $<.005$ \\
\hline & & & 09/13/04 & 1530 & .011 & $<.005$ & .150 & $<.041$ & $<.020$ & $<.005$ \\
\hline & & & 10/19/04 & 0845 & .007 & $<.005$ & .452 & $<.041$ & $<.020$ & $<.005$ \\
\hline & & & 11/17/04 & 1130 & $<.020$ & $<.005$ & .118 & $<.041$ & $<.020$ & $<.005$ \\
\hline & & & $12 / 08 / 04$ & 1150 & .013 & $<.005$ & .106 & $<.041$ & $<.020$ & $<.005$ \\
\hline \multirow[t]{10}{*}{5} & \multirow[t]{10}{*}{05490500} & \multirow{10}{*}{$\begin{array}{l}\text { Des Moines River at } \\
\text { Keosauqua }\end{array}$} & 03/18/04 & 1230 & .049 & $<.007$ & .124 & $<.041$ & $<.020$ & $<.005$ \\
\hline & & & $04 / 22 / 04$ & 0910 & .049 & $<.005$ & .147 & $<.041$ & $<.020$ & $<.005$ \\
\hline & & & 05/17/04 & 1400 & .422 & .020 & 2.3 & $<.041$ & $<.020$ & $<.007$ \\
\hline & & & 06/14/04 & 1400 & .776 & .017 & 2.6 & $<.041$ & $<.040$ & $<.005$ \\
\hline & & & 07/19/04 & 1600 & .148 & $<.005$ & 1.4 & $<.041$ & $<.020$ & $<.005$ \\
\hline & & & 08/16/04 & 1330 & .018 & $<.005$ & .488 & $<.041$ & $<.020$ & $<.005$ \\
\hline & & & 09/13/04 & 1330 & .012 & $<.005$ & .313 & $<.041$ & $<.020$ & $<.005$ \\
\hline & & & 10/19/04 & 1100 & .013 & $<.005$ & .240 & $<.041$ & $<.020$ & $<.005$ \\
\hline & & & $11 / 17 / 04$ & 1400 & $<.006$ & $<.005$ & .162 & $<.041$ & $<.020$ & $<.005$ \\
\hline & & & $12 / 08 / 04$ & 0900 & .015 & $<.005$ & .104 & $<.041$ & $<.020$ & $<.005$ \\
\hline \multirow[t]{5}{*}{6} & \multirow[t]{5}{*}{06485500} & \multirow[t]{5}{*}{ Big Sioux River at Akron } & 03/09/04 & 1200 & .500 & $<.005$ & .173 & $<.041$ & $<.020$ & $<.005$ \\
\hline & & & 04/13/04 & 0930 & .020 & $<.005$ & .045 & $<.041$ & $<.020$ & $<.005$ \\
\hline & & & 05/12/04 & 1030 & .063 & .008 & .140 & $<.041$ & $<.020$ & $<.005$ \\
\hline & & & $05 / 26 / 04$ & 1300 & .911 & .015 & .759 & E.008 & $<.020$ & E.005 \\
\hline & & & 06/02/04 & 1215 & 1.3 & .057 & 1.8 & E.016 & E.005 & .005 \\
\hline
\end{tabular}


Table 10. Concentrations of selected pesticides and pesticide degradation products determined by the U.S. Geological Survey National Water-Quality Laboratory, Lakewood, Colorado, using laboratory schedule 2001 for water samples collected from 10 rivers in lowa, 2004.-Continued

[E, estimated; EPTC, s-ethyl dipropylthiocarbamate; <, less than; --, not detected]

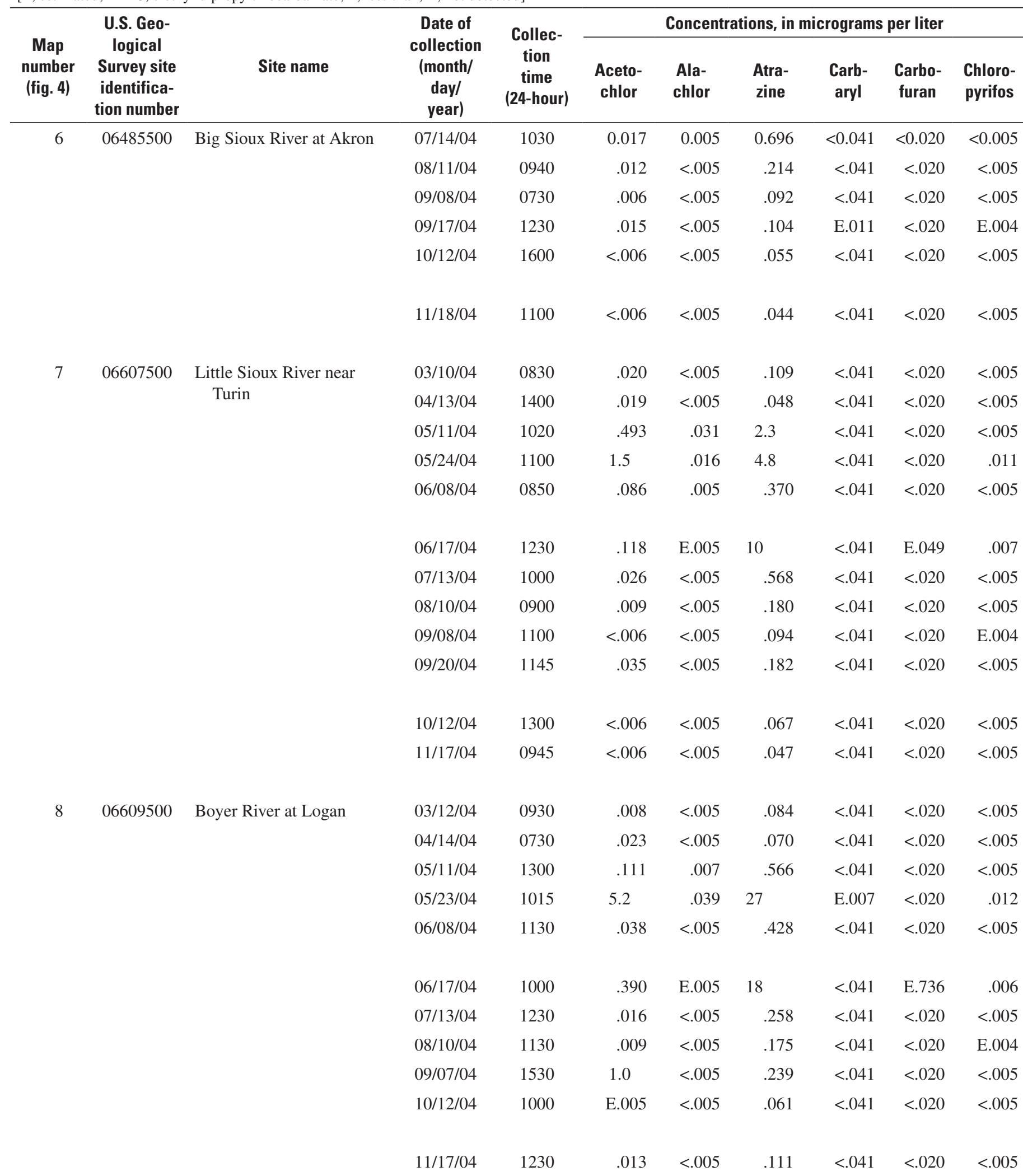


Table 10. Concentrations of selected pesticides and pesticide degradation products determined by the U.S. Geological Survey National Water-Quality Laboratory, Lakewood, Colorado, using laboratory schedule 2001 for water samples collected from 10 rivers in lowa, 2004.-Continued

[E, estimated; EPTC, s-ethyl dipropylthiocarbamate; <, less than; --, not detected]

\begin{tabular}{|c|c|c|c|c|c|c|c|c|c|c|}
\hline \multirow{2}{*}{$\begin{array}{c}\text { Map } \\
\text { number } \\
\text { (fig. 4) }\end{array}$} & \multirow{2}{*}{$\begin{array}{l}\text { U.S. Geo- } \\
\text { logical } \\
\text { Survey site } \\
\text { identifica- } \\
\text { tion number }\end{array}$} & \multirow[b]{2}{*}{ Site name } & \multirow{2}{*}{$\begin{array}{l}\text { Date of } \\
\text { collection } \\
\text { (month/ } \\
\text { day/ } \\
\text { year) }\end{array}$} & \multirow{2}{*}{$\begin{array}{l}\text { Collec- } \\
\text { tion } \\
\text { time } \\
\text { (24-hour) }\end{array}$} & \multicolumn{6}{|c|}{ Concentrations, in micrograms per liter } \\
\hline & & & & & $\begin{array}{l}\text { Aceto- } \\
\text { chlor }\end{array}$ & $\begin{array}{l}\text { Ala- } \\
\text { chlor }\end{array}$ & $\begin{array}{l}\text { Atra- } \\
\text { zine }\end{array}$ & $\begin{array}{l}\text { Carb- } \\
\text { aryl }\end{array}$ & $\begin{array}{l}\text { Carbo- } \\
\text { furan }\end{array}$ & $\begin{array}{l}\text { Chloro- } \\
\text { pyrifos }\end{array}$ \\
\hline \multirow[t]{11}{*}{9} & \multirow[t]{11}{*}{06810000} & \multirow{11}{*}{$\begin{array}{l}\text { Nishnabotna River above } \\
\text { Hamburg }\end{array}$} & 03/11/04 & 1030 & 0.009 & $<0.005$ & 0.078 & $<0.041$ & $<0.020$ & $<0.005$ \\
\hline & & & 03/29/04 & 1230 & .026 & $<.005$ & .160 & $<.041$ & $<.020$ & .006 \\
\hline & & & $04 / 12 / 04$ & 1300 & .017 & $<.005$ & .070 & $<.041$ & $<.020$ & $<.005$ \\
\hline & & & 05/10/04 & 1230 & 2.3 & .240 & E41.7 & E.007 & $<.020$ & .008 \\
\hline & & & 05/25/04 & 1045 & .884 & .051 & 8.7 & E.007 & $<.020$ & .027 \\
\hline & & & 06/07/04 & 1245 & .051 & .006 & .781 & $<.041$ & $<.020$ & $<.005$ \\
\hline & & & 07/12/04 & 1230 & .032 & $<.005$ & .681 & $<.041$ & $<.020$ & $<.005$ \\
\hline & & & 08/09/04 & 1230 & .015 & $<.005$ & .239 & $<.041$ & $<.020$ & E.004 \\
\hline & & & 09/07/04 & 1230 & .025 & $<.005$ & .273 & $<.041$ & $<.020$ & $<.005$ \\
\hline & & & $10 / 13 / 04$ & 0800 & $<.006$ & $<.005$ & .065 & $<.041$ & $<.020$ & $<.005$ \\
\hline & & & $11 / 16 / 04$ & 1300 & E.004 & $<.005$ & .041 & $<.041$ & $<.020$ & $<.005$ \\
\hline \multirow[t]{7}{*}{10} & \multirow[t]{7}{*}{06904010} & \multirow{7}{*}{$\begin{array}{l}\text { Chariton River near } \\
\text { Moulton }\end{array}$} & 03/18/04 & 0900 & .011 & .006 & .657 & $<.041$ & $<.020$ & $<.005$ \\
\hline & & & 04/22/04 & 1320 & .022 & $<.005$ & .493 & $<.041$ & $<.020$ & $<.005$ \\
\hline & & & 05/17/04 & 1100 & .065 & $<.005$ & .555 & $<.041$ & $<.020$ & $<.005$ \\
\hline & & & 06/14/04 & 1050 & .206 & $<.005$ & 1.3 & $<.041$ & $<.020$ & $<.005$ \\
\hline & & & 07/19/04 & 1230 & .083 & $<.005$ & 1.1 & $<.041$ & $<.020$ & $<.005$ \\
\hline & & & 08/16/04 & 1030 & .047 & $<.005$ & 1.1 & $<.041$ & $<.020$ & $<.005$ \\
\hline & & & 09/13/04 & 1030 & .036 & $<.005$ & .853 & $<.041$ & $<.020$ & $<.005$ \\
\hline
\end{tabular}


Table 10. Concentrations of selected pesticides and pesticide degradation products determined by the U.S. Geological Survey National Water-Quality Laboratory, Lakewood, Colorado, using laboratory schedule 2001 for water samples collected from 10 rivers in lowa, 2004.-Continued

[E, estimated; EPTC, s-ethyl dipropylthiocarbamate; <, less than; --, not detected]

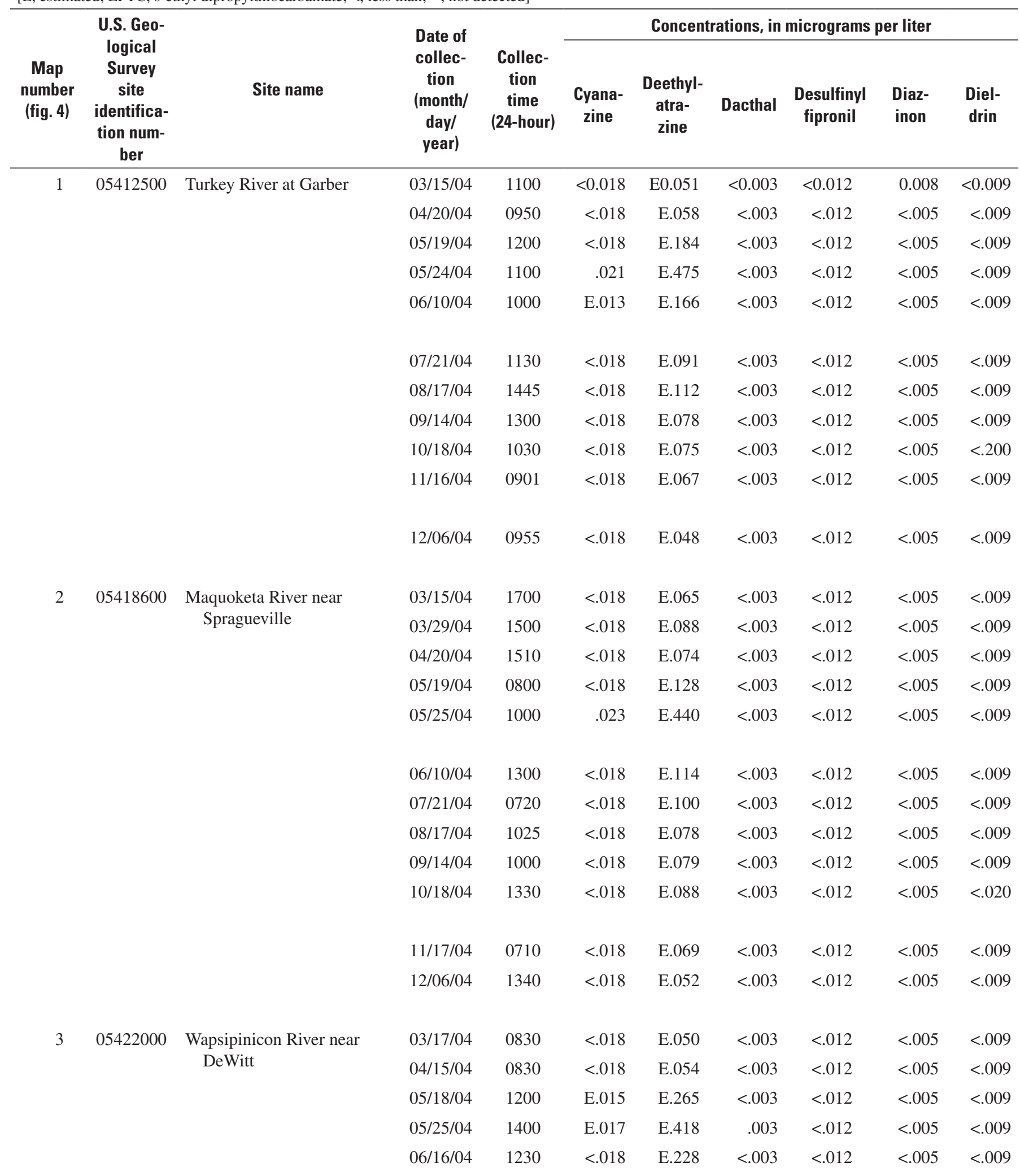


Table 10. Concentrations of selected pesticides and pesticide degradation products determined by the U.S. Geological Survey National Water-Quality Laboratory, Lakewood, Colorado, using laboratory schedule 2001 for water samples collected from 10 rivers in lowa, 2004.-Continued

[E, estimated; EPTC, s-ethyl dipropylthiocarbamate; <, less than; --, not detected]

\begin{tabular}{|c|c|c|c|c|c|c|c|c|c|c|}
\hline \multirow[b]{2}{*}{$\begin{array}{c}\text { Map } \\
\text { number } \\
\text { (fig. 4) }\end{array}$} & \multirow{2}{*}{$\begin{array}{l}\text { U.S. Geo- } \\
\text { logical } \\
\text { Survey } \\
\text { site } \\
\text { identifica- } \\
\text { tion num- } \\
\text { ber }\end{array}$} & \multirow[b]{2}{*}{ Site name } & \multirow{2}{*}{$\begin{array}{c}\text { Date of } \\
\text { collec- } \\
\text { tion } \\
\text { (month/ } \\
\text { day/ } \\
\text { year) }\end{array}$} & \multirow{2}{*}{$\begin{array}{c}\text { Collec- } \\
\text { tion } \\
\text { time } \\
\text { (24-hour) }\end{array}$} & \multicolumn{6}{|c|}{ Concentrations, in micrograms per liter } \\
\hline & & & & & $\begin{array}{l}\text { Cyana- } \\
\text { zine }\end{array}$ & $\begin{array}{c}\text { Deethyl- } \\
\text { atra- } \\
\text { zine }\end{array}$ & Dacthal & $\begin{array}{l}\text { Desulfinyl } \\
\text { fipronil }\end{array}$ & $\begin{array}{l}\text { Diaz- } \\
\text { inon }\end{array}$ & $\begin{array}{l}\text { Diel- } \\
\text { drin }\end{array}$ \\
\hline \multirow{3}{*}{3} & \multirow{3}{*}{05422000} & \multirow{3}{*}{$\begin{array}{l}\text { Wapsipinicon River near } \\
\text { DeWitt }\end{array}$} & $09 / 14 / 04$ & 0730 & $<.018$ & E.068 & $<.003$ & $<.012$ & $<.005$ & $<.009$ \\
\hline & & & $10 / 18 / 04$ & 1520 & $<.018$ & E.067 & $<.003$ & $<.012$ & $<.005$ & $<.009$ \\
\hline & & & $11 / 17 / 04$ & 0845 & $<.018$ & E.053 & $<.003$ & $<.012$ & $<.005$ & $<.009$ \\
\hline \multirow{7}{*}{4} & \multirow{7}{*}{05474000} & \multirow{7}{*}{ Skunk River at Augusta } & $04 / 15 / 04$ & 1345 & $<.018$ & E.038 & $<.003$ & $<.012$ & $<.005$ & $<.009$ \\
\hline & & & 05/18/04 & 0730 & E.007 & E.113 & $<.003$ & $<.012$ & $<.005$ & $<.009$ \\
\hline & & & $06 / 16 / 04$ & 0900 & E.018 & E.433 & $<.003$ & $<.012$ & $<.005$ & $<.009$ \\
\hline & & & 07/20/04 & 0800 & $<.018$ & E.079 & $<.003$ & $<.012$ & $<.005$ & $<.009$ \\
\hline & & & $08 / 16 / 04$ & 1615 & $<.018$ & E.056 & $<.003$ & $<.012$ & $<.005$ & $<.009$ \\
\hline & & & 09/13/04 & 1530 & $<.018$ & E.051 & $<.003$ & $<.012$ & $<.005$ & $<.009$ \\
\hline & & & $10 / 19 / 04$ & 0845 & $<.018$ & E.034 & $<.003$ & E.004 & $<.005$ & $<.009$ \\
\hline \multirow{8}{*}{5} & \multirow{8}{*}{05490500} & \multirow{8}{*}{$\begin{array}{l}\text { Des Moines River at } \\
\text { Keosauqua }\end{array}$} & 05/17/04 & 1400 & E.008 & E.071 & $<.003$ & E.004 & $<.005$ & $<.009$ \\
\hline & & & $06 / 14 / 04$ & 1400 & $<.018$ & E.199 & $<.003$ & $<.012$ & $<.005$ & $<.009$ \\
\hline & & & $07 / 19 / 04$ & 1600 & $<.018$ & E. 126 & $<.003$ & $<.012$ & $<.005$ & $<.009$ \\
\hline & & & $08 / 16 / 04$ & 1330 & $<.018$ & E.067 & $<.003$ & $<.012$ & $<.005$ & $<.009$ \\
\hline & & & 09/13/04 & 1330 & $<.018$ & E.059 & $<.003$ & $<.012$ & $<.005$ & $<.009$ \\
\hline & & & $10 / 19 / 04$ & 1100 & $<.018$ & E.052 & $<.003$ & $<.012$ & $<.005$ & $<.009$ \\
\hline & & & $11 / 17 / 04$ & 1400 & $<.018$ & E.040 & $<.003$ & $<.012$ & $<.005$ & $<.009$ \\
\hline & & & $12 / 08 / 04$ & 0900 & $<.018$ & E.024 & $<.003$ & $<.012$ & $<.005$ & $<.009$ \\
\hline \multirow[t]{3}{*}{6} & \multirow[t]{3}{*}{06485500} & \multirow[t]{3}{*}{ Big Sioux River at Akron } & 03/09/04 & 1200 & $<.018$ & E.042 & $<.003$ & $<.012$ & $<.005$ & $<.009$ \\
\hline & & & $04 / 13 / 04$ & 0930 & $<.018$ & E.015 & $<.003$ & $<.012$ & $<.005$ & $<.009$ \\
\hline & & & $05 / 12 / 04$ & 1030 & $<.018$ & E.030 & $<.003$ & E.003 & $<.005$ & $<.009$ \\
\hline
\end{tabular}


Table 10. Concentrations of selected pesticides and pesticide degradation products determined by the U.S. Geological Survey National Water-Quality Laboratory, Lakewood, Colorado, using laboratory schedule 2001 for water samples collected from 10 rivers in lowa, 2004.-Continued

[E, estimated; EPTC, s-ethyl dipropylthiocarbamate; <, less than; --, not detected]

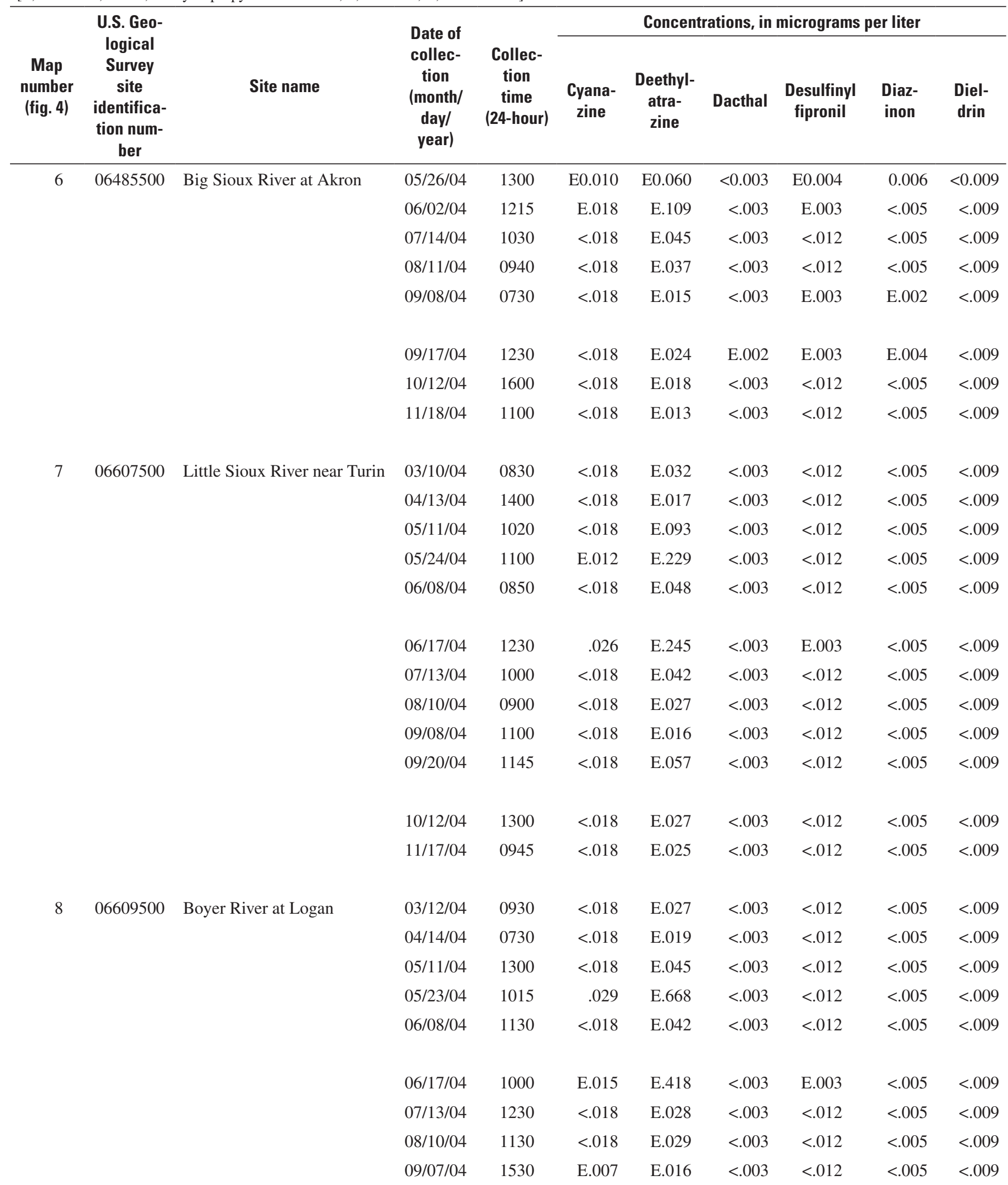


Table 10. Concentrations of selected pesticides and pesticide degradation products determined by the U.S. Geological Survey National Water-Quality Laboratory, Lakewood, Colorado, using laboratory schedule 2001 for water samples collected from 10 rivers in lowa, 2004.-Continued

[E, estimated; EPTC, s-ethyl dipropylthiocarbamate; <, less than; --, not detected]

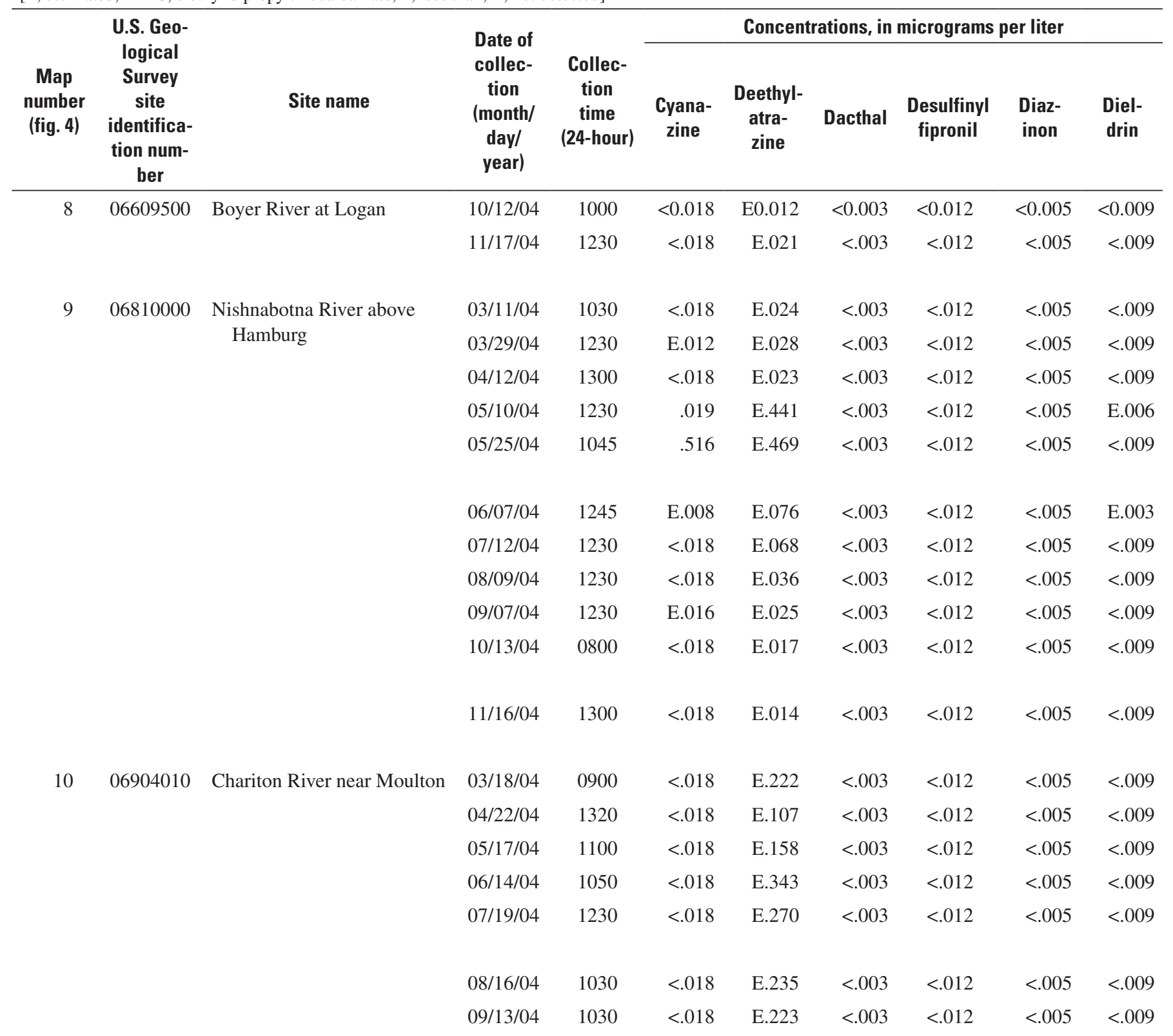


Table 10. Concentrations of selected pesticides and pesticide degradation products determined by the U.S. Geological Survey National Water-Quality Laboratory, Lakewood, Colorado, using laboratory schedule 2001 for water samples collected from 10 rivers in lowa, 2004.-Continued

[E, estimated; EPTC, s-ethyl dipropylthiocarbamate; <, less than; --, not detected]

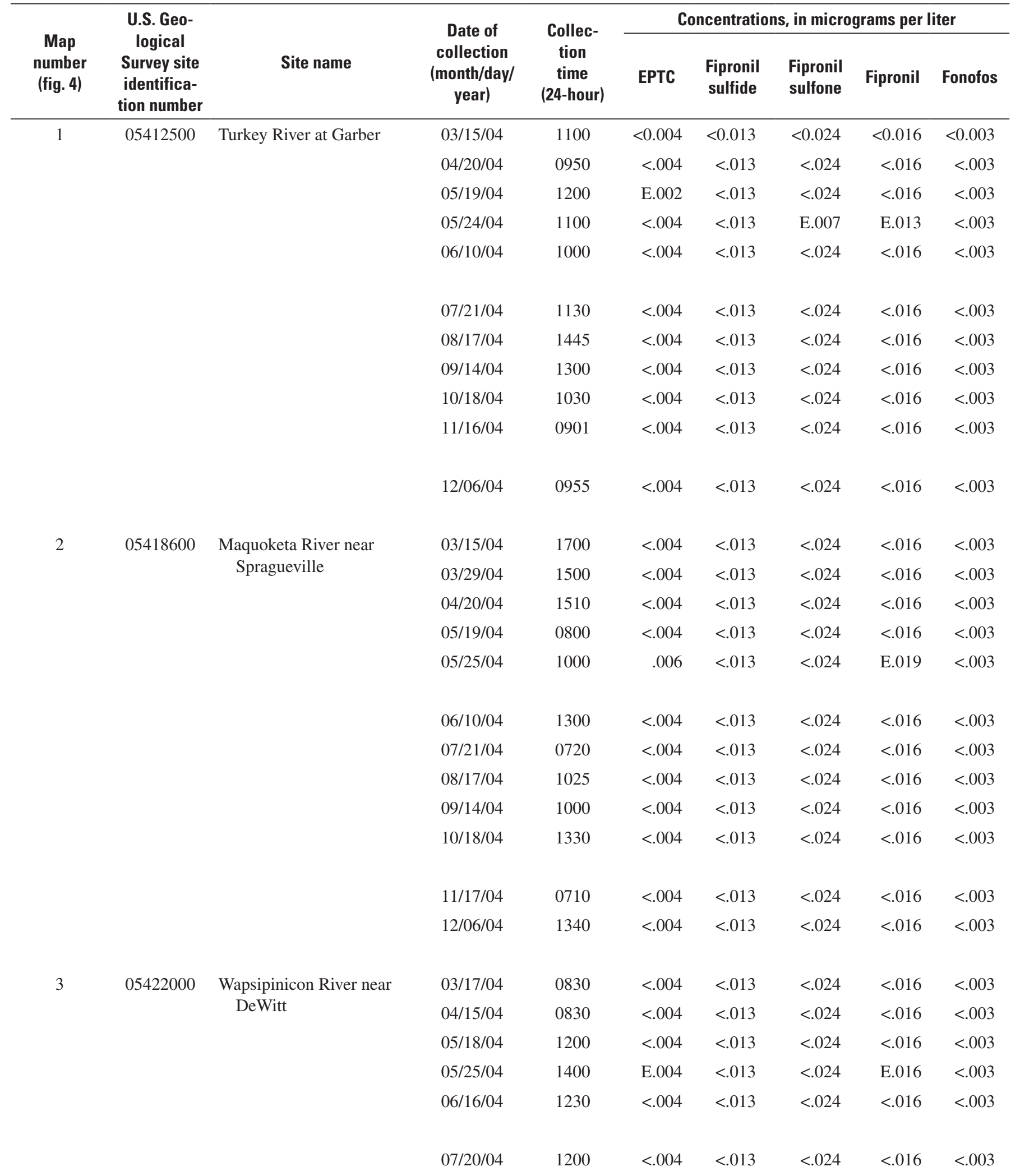


Table 10. Concentrations of selected pesticides and pesticide degradation products determined by the U.S. Geological Survey National Water-Quality Laboratory, Lakewood, Colorado, using laboratory schedule 2001 for water samples collected from 10 rivers in lowa, 2004.-Continued

[E, estimated; EPTC, s-ethyl dipropylthiocarbamate; <, less than; --, not detected]

\begin{tabular}{|c|c|c|c|c|c|c|c|c|c|}
\hline \multirow{2}{*}{$\begin{array}{c}\text { Map } \\
\text { number } \\
\text { (fig. 4) }\end{array}$} & \multirow{2}{*}{$\begin{array}{l}\text { U.S. Geo- } \\
\text { logical } \\
\text { Survey site } \\
\text { identifica- } \\
\text { tion number }\end{array}$} & \multirow[b]{2}{*}{ Site name } & \multirow{2}{*}{$\begin{array}{c}\text { Date of } \\
\text { collection } \\
\text { (month/day/ } \\
\text { year) }\end{array}$} & \multirow{2}{*}{$\begin{array}{l}\text { Collec- } \\
\text { tion } \\
\text { time } \\
\text { (24-hour) }\end{array}$} & \multicolumn{5}{|c|}{ Concentrations, in micrograms per liter } \\
\hline & & & & & EPTC & $\begin{array}{l}\text { Fipronil } \\
\text { sulfide }\end{array}$ & $\begin{array}{l}\text { Fipronil } \\
\text { sulfone }\end{array}$ & Fipronil & Fonofos \\
\hline \multirow[t]{4}{*}{3} & \multirow[t]{4}{*}{05422000} & \multirow{4}{*}{$\begin{array}{l}\text { Wapsipinicon River near } \\
\text { DeWitt }\end{array}$} & 08/17/04 & 0745 & $<0.004$ & $<0.013$ & $<0.024$ & $<0.016$ & $<0.003$ \\
\hline & & & 09/14/04 & 0730 & $<.004$ & $<.013$ & $<.024$ & $<.016$ & $<.003$ \\
\hline & & & $11 / 17 / 04$ & 0845 & $<.004$ & $<.013$ & $<.024$ & $<.016$ & $<.003$ \\
\hline & & & $12 / 06 / 04$ & 1615 & $<.004$ & $<.013$ & $<.024$ & $<.016$ & $<.003$ \\
\hline \multirow[t]{7}{*}{4} & \multirow[t]{7}{*}{05474000} & \multirow[t]{7}{*}{ Skunk River at Augusta } & 03/17/04 & 1430 & $<.004$ & $<.013$ & $<.024$ & $<.016$ & $<.003$ \\
\hline & & & 07/20/04 & 0800 & $<.004$ & $<.013$ & $<.024$ & $<.016$ & $<.003$ \\
\hline & & & 08/16/04 & 1615 & $<.004$ & $<.013$ & $<.024$ & $<.016$ & $<.003$ \\
\hline & & & 09/13/04 & 1530 & $<.004$ & $<.013$ & $<.024$ & $<.016$ & $<.003$ \\
\hline & & & $10 / 19 / 04$ & 0845 & $<.004$ & $<.013$ & $<.024$ & $<.016$ & $<.003$ \\
\hline & & & $11 / 17 / 04$ & 1130 & $<.004$ & $<.013$ & $<.024$ & $<.016$ & $<.003$ \\
\hline & & & $12 / 08 / 04$ & 1150 & $<.004$ & $<.013$ & $<.024$ & $<.016$ & $<.003$ \\
\hline \multirow{6}{*}{5} & \multirow{6}{*}{05490500} & \multirow{6}{*}{$\begin{array}{l}\text { Des Moines River at } \\
\text { Keosauqua }\end{array}$} & 07/19/04 & 1600 & $<.004$ & $<.013$ & $<.024$ & $<.016$ & $<.003$ \\
\hline & & & 08/16/04 & 1330 & $<.004$ & $<.013$ & $<.024$ & $<.016$ & $<.003$ \\
\hline & & & 09/13/04 & 1330 & $<.004$ & $<.013$ & $<.024$ & $<.016$ & $<.003$ \\
\hline & & & $10 / 19 / 04$ & 1100 & $<.004$ & $<.013$ & $<.024$ & $<.016$ & $<.003$ \\
\hline & & & $11 / 17 / 04$ & 1400 & $<.004$ & $<.013$ & $<.024$ & $<.016$ & $<.003$ \\
\hline & & & $12 / 08 / 04$ & 0900 & $<.004$ & $<.013$ & $<.024$ & $<.016$ & $<.003$ \\
\hline \multirow[t]{5}{*}{6} & \multirow[t]{5}{*}{06485500} & \multirow[t]{5}{*}{ Big Sioux River at Akron } & 03/09/04 & 1200 & $<.004$ & $<.013$ & $<.024$ & $<.016$ & $<.003$ \\
\hline & & & 04/13/04 & 0930 & $<.004$ & $<.013$ & $<.024$ & $<.016$ & $<.003$ \\
\hline & & & 05/12/04 & 1030 & E.003 & $<.013$ & $<.024$ & $<.016$ & $<.003$ \\
\hline & & & 05/26/04 & 1300 & E.003 & $<.013$ & $<.024$ & E.014 & $<.003$ \\
\hline & & & 06/02/04 & 1215 & .008 & $<.013$ & E.005 & E.019 & $<.003$ \\
\hline
\end{tabular}


Table 10. Concentrations of selected pesticides and pesticide degradation products determined by the U.S. Geological Survey National Water-Quality Laboratory, Lakewood, Colorado, using laboratory schedule 2001 for water samples collected from 10 rivers in lowa, 2004.-Continued

[E, estimated; EPTC, s-ethyl dipropylthiocarbamate; <, less than; --, not detected]

\begin{tabular}{|c|c|c|c|c|c|c|c|c|c|}
\hline \multirow{2}{*}{$\begin{array}{c}\text { Map } \\
\text { number } \\
\text { (fig. 4) }\end{array}$} & \multirow{2}{*}{$\begin{array}{l}\text { U.S. Geo- } \\
\text { logical } \\
\text { Survey site } \\
\text { identifica- } \\
\text { tion number }\end{array}$} & \multirow{2}{*}{ Site name } & \multirow{2}{*}{$\begin{array}{c}\text { Date of } \\
\text { collection } \\
\text { (month/day/ } \\
\text { year) }\end{array}$} & \multirow{2}{*}{$\begin{array}{c}\text { Collec- } \\
\text { tion } \\
\text { time } \\
\text { (24-hour) }\end{array}$} & \multicolumn{5}{|c|}{ Concentrations, in micrograms per liter } \\
\hline & & & & & EPTC & $\begin{array}{l}\text { Fipronil } \\
\text { sulfide }\end{array}$ & $\begin{array}{l}\text { Fipronil } \\
\text { sulfone }\end{array}$ & Fipronil & Fonofos \\
\hline \multirow[t]{5}{*}{6} & 06485500 & Big Sioux River at Akron & 07/14/04 & 1030 & $<0.004$ & $<0.013$ & $<0.024$ & $<0.016$ & $<0.003$ \\
\hline & & & 08/11/04 & 0940 & $<.004$ & $<.013$ & $<.024$ & $<.016$ & $<.003$ \\
\hline & & & $09 / 17 / 04$ & 1230 & $<.004$ & $<.013$ & $<.024$ & $<.016$ & $<.003$ \\
\hline & & & $10 / 12 / 04$ & 1600 & $<.004$ & $<.013$ & $<.024$ & $<.016$ & $<.003$ \\
\hline & & & $11 / 18 / 04$ & 1100 & $<.004$ & $<.013$ & $<.024$ & $<.016$ & $<.003$ \\
\hline \multirow{7}{*}{7} & & & 05/11/04 & 1020 & $<.004$ & $<.013$ & $<.024$ & $<.016$ & $<.003$ \\
\hline & & & $05 / 24 / 04$ & 1100 & E.003 & $<.013$ & $<.024$ & E.009 & $<.003$ \\
\hline & & & 06/08/04 & 0850 & $<.004$ & $<.013$ & $<.024$ & $<.016$ & $<.003$ \\
\hline & & & $06 / 17 / 04$ & 1230 & $<.004$ & E.003 & E.006 & E.014 & $<.003$ \\
\hline & & & 07/13/04 & 1000 & $<.004$ & $<.013$ & $<.024$ & $<.016$ & $<.003$ \\
\hline & & & 08/10/04 & 0900 & $<.008$ & $<.013$ & $<.024$ & $<.016$ & $<.003$ \\
\hline & & & 09/08/04 & 1100 & $<.004$ & $<.013$ & $<.024$ & $<.016$ & $<.003$ \\
\hline \multirow{9}{*}{8} & & & $04 / 14 / 04$ & 0730 & $<.004$ & $<.013$ & $<.024$ & $<.016$ & $<.003$ \\
\hline & & & 05/11/04 & 1300 & $<.004$ & $<.013$ & $<.024$ & $<.016$ & $<.003$ \\
\hline & & & $05 / 23 / 04$ & 1015 & E.003 & $<.013$ & $<.024$ & E.006 & $<.003$ \\
\hline & & & 06/08/04 & 1130 & $<.004$ & $<.013$ & $<.024$ & $<.016$ & $<.003$ \\
\hline & & & 06/17/04 & 1000 & $<.004$ & $<.013$ & E.005 & E.010 & $<.003$ \\
\hline & & & 07/13/04 & 1230 & $<.004$ & $<.013$ & $<.024$ & $<.016$ & $<.003$ \\
\hline & & & 08/10/04 & 1130 & $<.004$ & $<.013$ & $<.024$ & $<.016$ & $<.003$ \\
\hline & & & 09/07/04 & 1530 & $<.004$ & $<.013$ & $<.024$ & $<.016$ & $<.003$ \\
\hline & & & $10 / 12 / 04$ & 1000 & $<.004$ & $<.013$ & $<.024$ & $<.016$ & $<.003$ \\
\hline & & & $11 / 17 / 04$ & 1230 & $<.004$ & $<.013$ & $<.024$ & $<.016$ & $<.003$ \\
\hline
\end{tabular}


Table 10. Concentrations of selected pesticides and pesticide degradation products determined by the U.S. Geological Survey National Water-Quality Laboratory, Lakewood, Colorado, using laboratory schedule 2001 for water samples collected from 10 rivers in lowa, 2004.-Continued

[E, estimated; EPTC, s-ethyl dipropylthiocarbamate; <, less than; --, not detected]

\begin{tabular}{|c|c|c|c|c|c|c|c|c|c|}
\hline \multirow{2}{*}{$\begin{array}{c}\text { Map } \\
\text { number } \\
\text { (fig. 4) }\end{array}$} & \multirow{2}{*}{$\begin{array}{l}\text { U.S. Geo- } \\
\text { logical } \\
\text { Survey site } \\
\text { identifica- } \\
\text { tion number }\end{array}$} & \multirow{2}{*}{ Site name } & \multirow{2}{*}{$\begin{array}{c}\text { Date of } \\
\text { collection } \\
\text { (month/day/ } \\
\text { year) }\end{array}$} & \multirow{2}{*}{$\begin{array}{l}\text { Collec- } \\
\text { tion } \\
\text { time } \\
\text { (24-hour) }\end{array}$} & \multicolumn{5}{|c|}{ Concentrations, in micrograms per liter } \\
\hline & & & & & EPTC & $\begin{array}{l}\text { Fipronil } \\
\text { sulfide }\end{array}$ & $\begin{array}{l}\text { Fipronil } \\
\text { sulfone }\end{array}$ & Fipronil & Fonofos \\
\hline \multirow[t]{11}{*}{9} & \multirow[t]{11}{*}{06810000} & \multirow{11}{*}{$\begin{array}{l}\text { Nishnabotna River above } \\
\text { Hamburg }\end{array}$} & 03/11/04 & 1030 & $<0.004$ & $<0.013$ & $<0.024$ & $<0.016$ & $<0.003$ \\
\hline & & & 03/29/04 & 1230 & $<.004$ & $<.013$ & $<.024$ & $<.016$ & $<.003$ \\
\hline & & & $04 / 12 / 04$ & 1300 & $<.004$ & $<.013$ & $<.024$ & $<.016$ & $<.003$ \\
\hline & & & 05/10/04 & 1230 & $<.004$ & $<.013$ & E.006 & E.009 & $<.003$ \\
\hline & & & $05 / 25 / 04$ & 1045 & $<.004$ & $<.013$ & E.008 & E.031 & .024 \\
\hline & & & 06/07/04 & 1245 & $<.004$ & $<.013$ & $<.024$ & $<.016$ & $<.003$ \\
\hline & & & 07/12/04 & 1230 & $<.004$ & $<.013$ & $<.024$ & $<.016$ & $<.003$ \\
\hline & & & 08/09/04 & 1230 & $<.004$ & $<.013$ & $<.024$ & $<.016$ & $<.003$ \\
\hline & & & 09/07/04 & 1230 & $<.004$ & $<.013$ & $<.024$ & $<.016$ & $<.003$ \\
\hline & & & $10 / 13 / 04$ & 0800 & $<.004$ & $<.013$ & $<.024$ & $<.016$ & $<.003$ \\
\hline & & & $11 / 16 / 04$ & 1300 & $<.004$ & $<.013$ & $<.024$ & $<.016$ & $<.003$ \\
\hline \multirow[t]{7}{*}{10} & \multirow[t]{7}{*}{06904010} & \multirow{7}{*}{$\begin{array}{l}\text { Chariton River near } \\
\text { Moulton }\end{array}$} & 03/18/04 & 0900 & $<.004$ & $<.013$ & $<.024$ & $<.016$ & $<.003$ \\
\hline & & & $04 / 22 / 04$ & 1320 & $<.004$ & $<.013$ & $<.024$ & $<.016$ & $<.003$ \\
\hline & & & 05/17/04 & 1100 & $<.004$ & $<.013$ & $<.024$ & $<.016$ & $<.003$ \\
\hline & & & 06/14/04 & 1050 & $<.004$ & $<.013$ & $<.024$ & $<.016$ & $<.003$ \\
\hline & & & 07/19/04 & 1230 & $<.004$ & $<.013$ & $<.024$ & $<.016$ & $<.003$ \\
\hline & & & 08/16/04 & 1030 & $<.004$ & $<.013$ & $<.024$ & $<.016$ & $<.003$ \\
\hline & & & 09/13/04 & 1030 & $<.004$ & $<.013$ & $<.024$ & $<.016$ & $<.003$ \\
\hline
\end{tabular}


Table 10. Concentrations of selected pesticides and pesticide degradation products determined by the U.S. Geological Survey National Water-Quality Laboratory, Lakewood, Colorado, using laboratory schedule 2001 for water samples collected from 10 rivers in lowa, 2004 - Continued

[E, estimated; EPTC, s-ethyl dipropylthiocarbamate; <, less than; --, not detected]

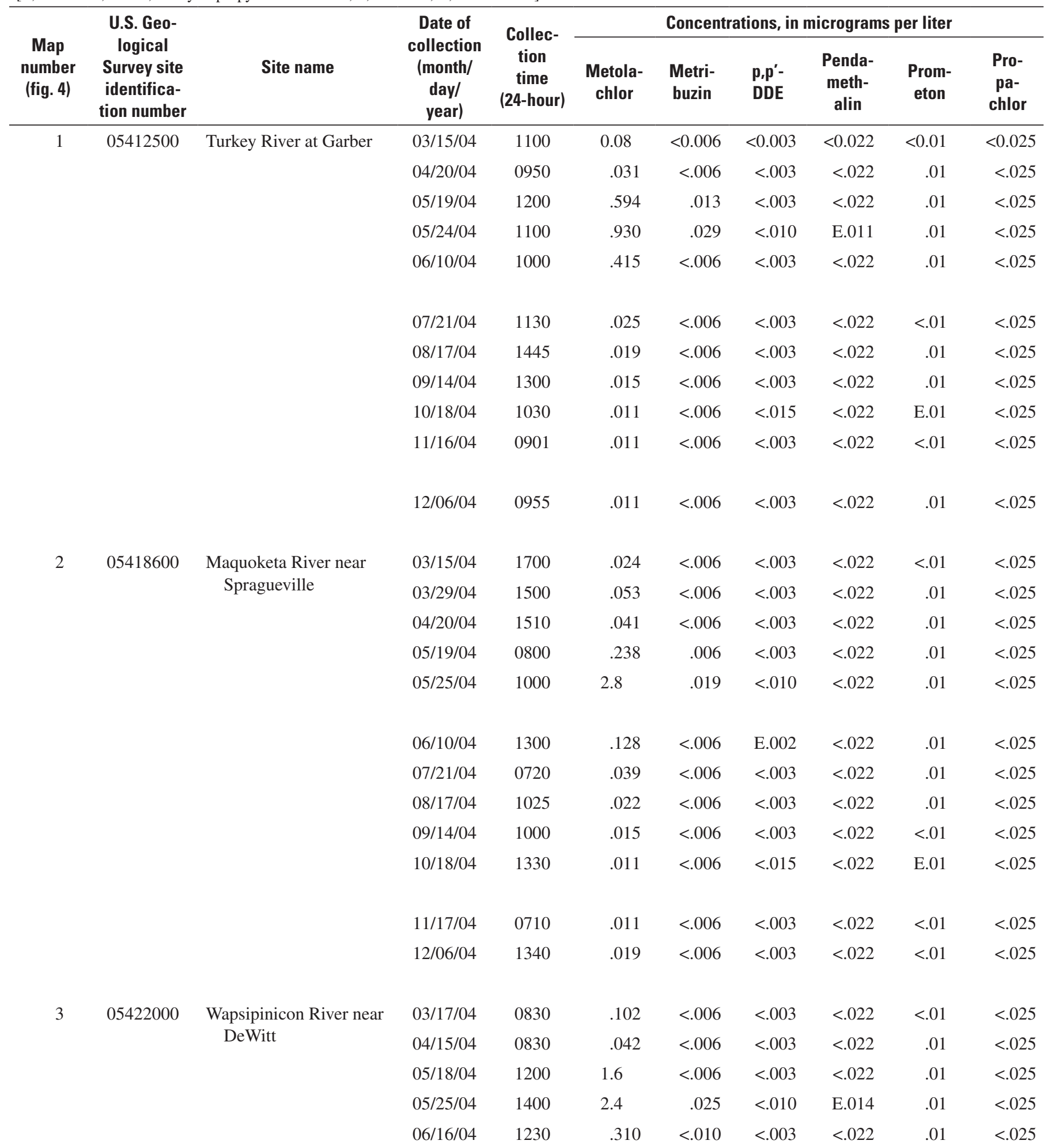


Table 10. Concentrations of selected pesticides and pesticide degradation products determined by the U.S. Geological Survey National Water-Quality Laboratory, Lakewood, Colorado, using laboratory schedule 2001 for water samples collected from 10 rivers in lowa, 2004 - Continued

[E, estimated; EPTC, s-ethyl dipropylthiocarbamate; <, less than; --, not detected]

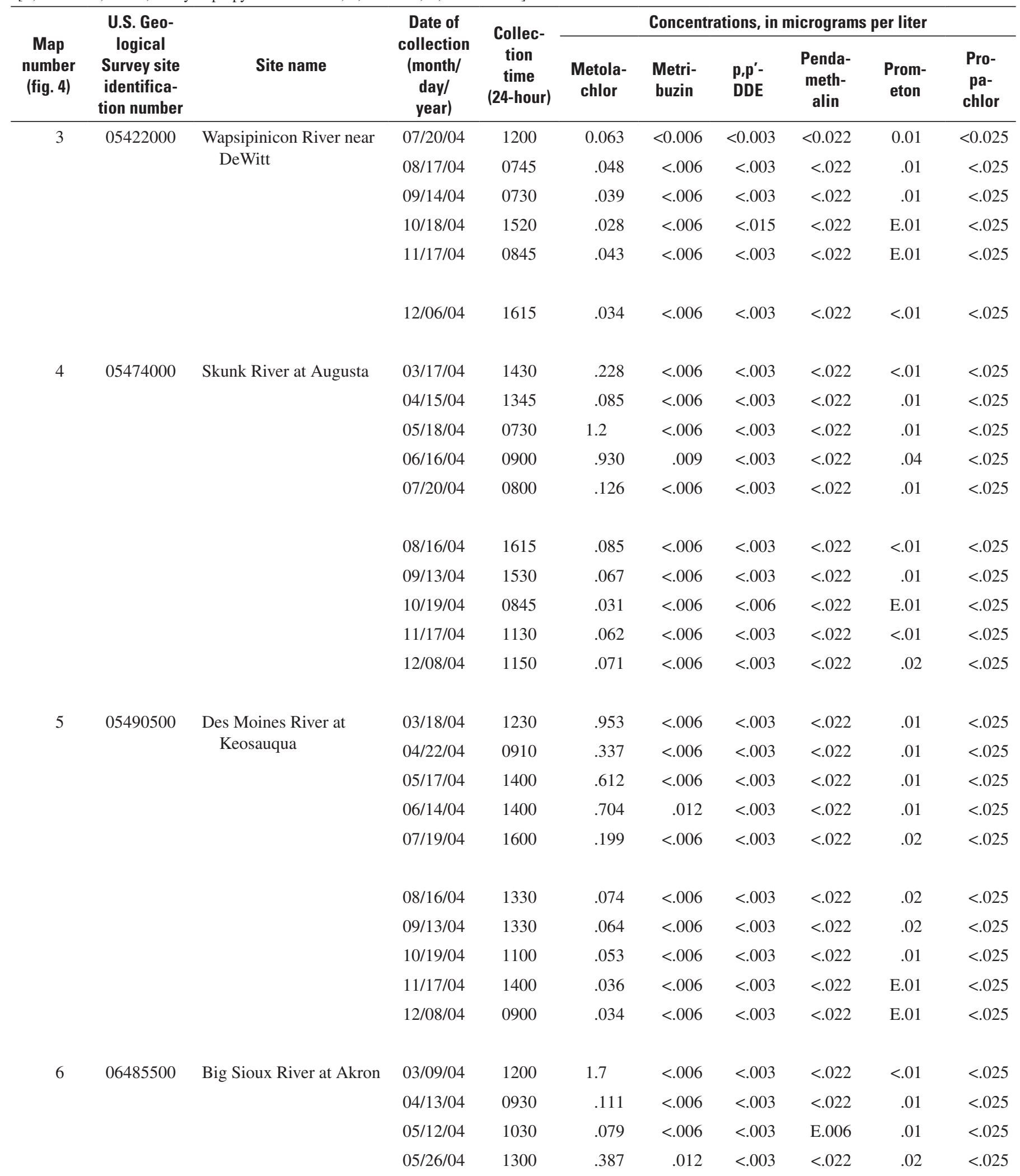


Table 10. Concentrations of selected pesticides and pesticide degradation products determined by the U.S. Geological Survey National Water-Quality Laboratory, Lakewood, Colorado, using laboratory schedule 2001 for water samples collected from 10 rivers in lowa, 2004 - Continued

[E, estimated; EPTC, s-ethyl dipropylthiocarbamate; <, less than; --, not detected]

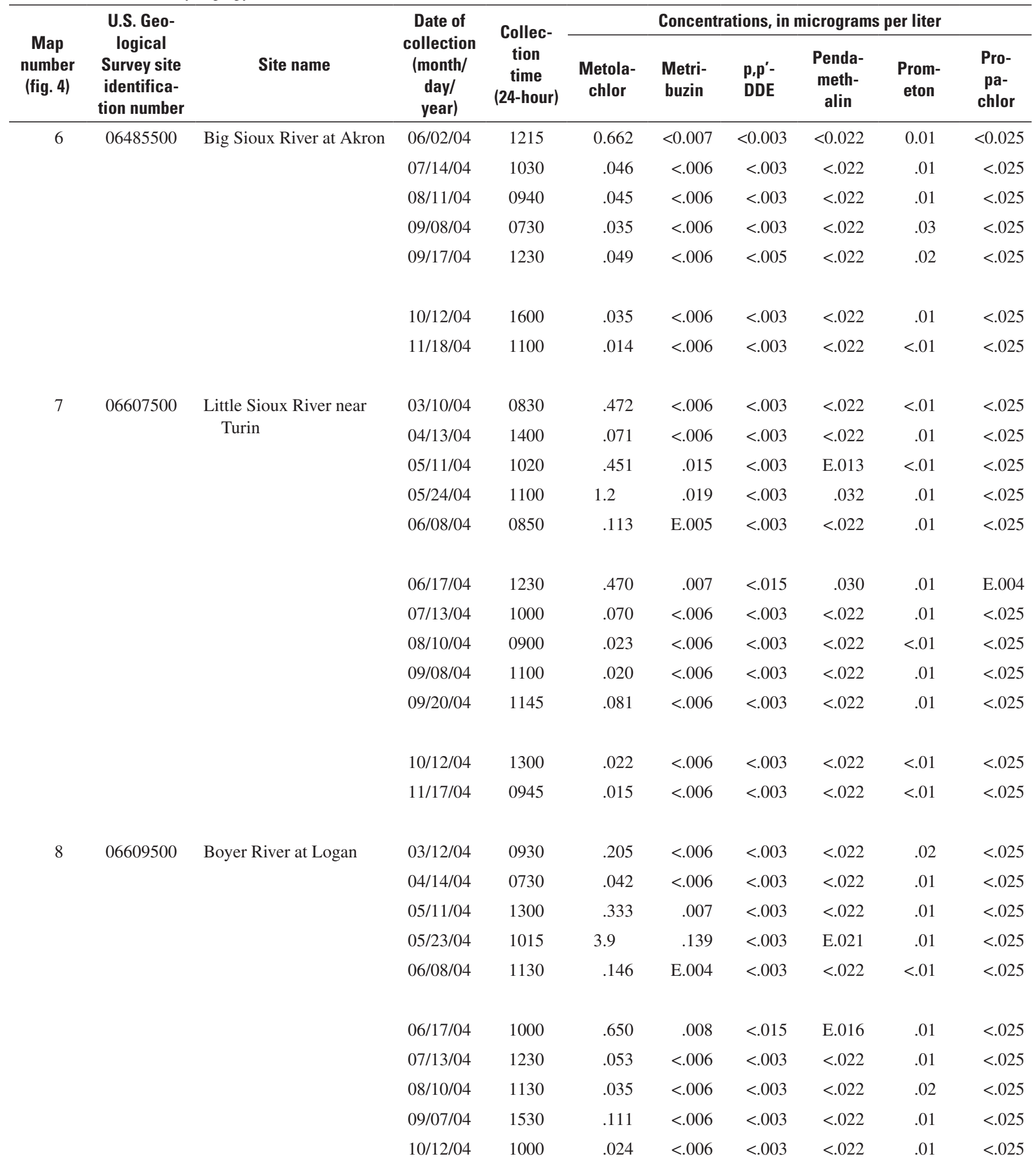


Table 10. Concentrations of selected pesticides and pesticide degradation products determined by the U.S. Geological Survey National Water-Quality Laboratory, Lakewood, Colorado, using laboratory schedule 2001 for water samples collected from 10 rivers in lowa, 2004 -Continued

[E, estimated; EPTC, s-ethyl dipropylthiocarbamate; <, less than; --, not detected]

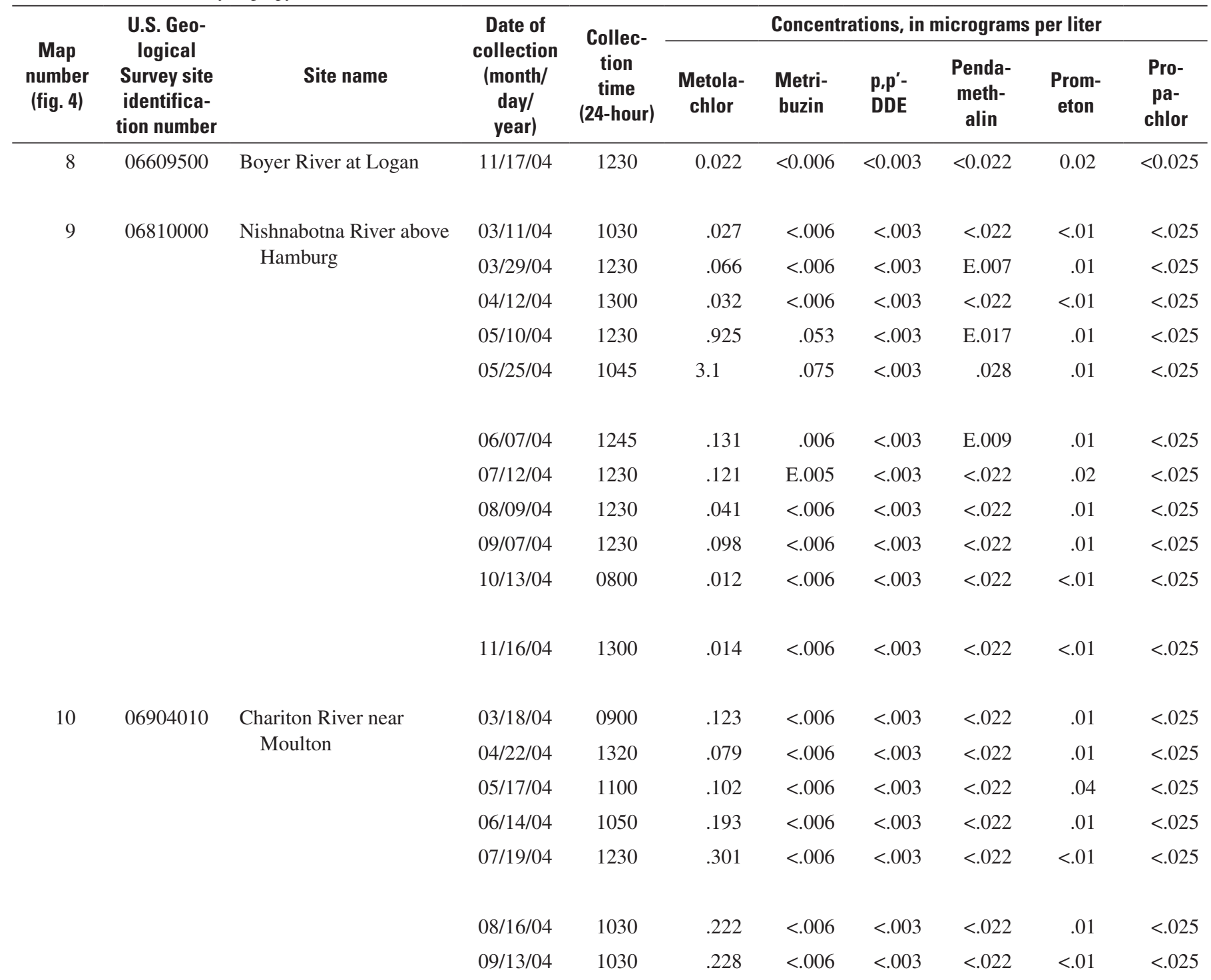


Table 10. Concentrations of selected pesticides and pesticide degradation products determined by the U.S. Geological Survey National Water-Quality Laboratory, Lakewood, Colorado, using laboratory schedule 2001 for water samples collected from 10 rivers in lowa, 2004. - Continued

[E, estimated; EPTC, s-ethyl dipropylthiocarbamate; <, less than; --, not detected]

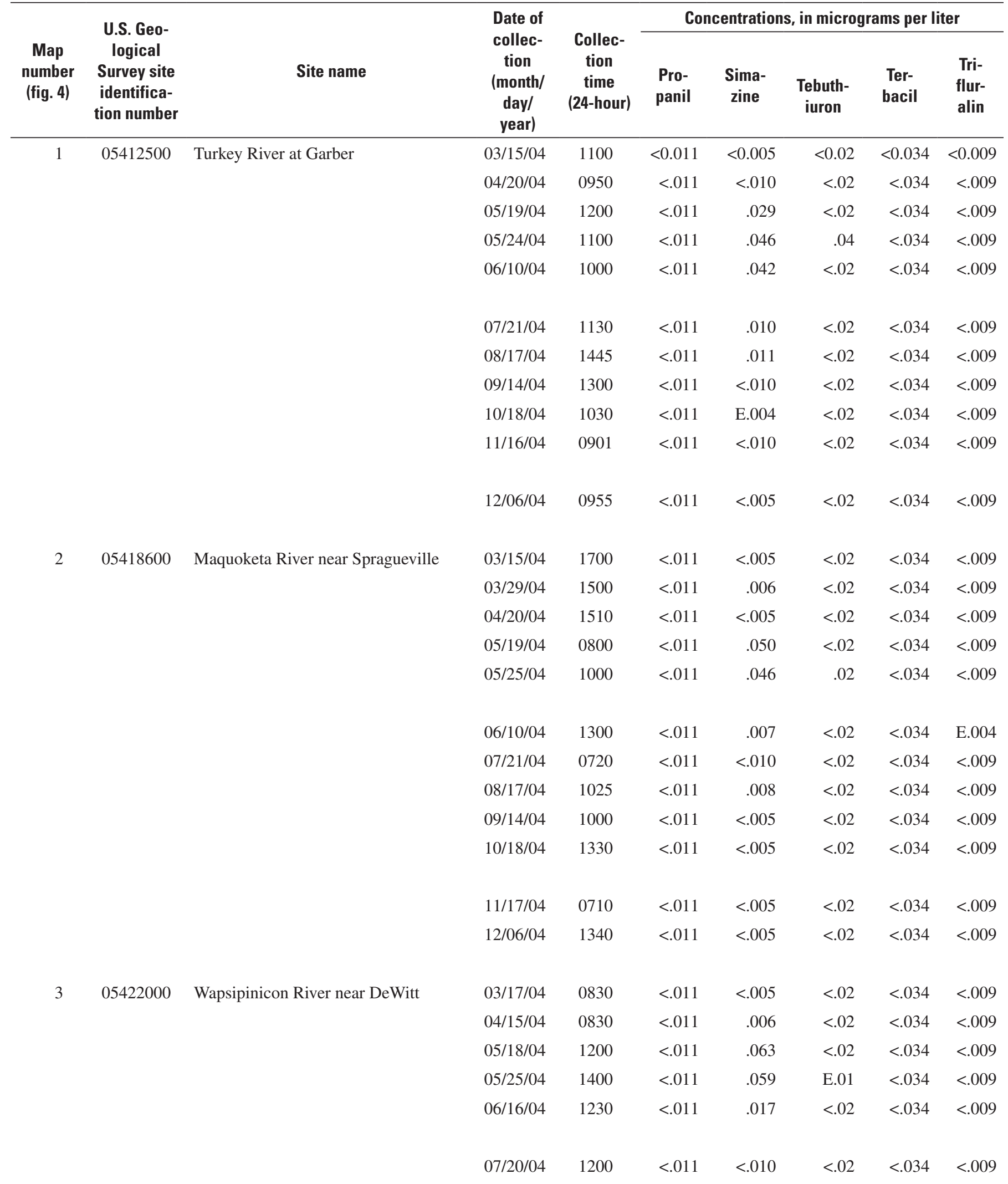


Table 10. Concentrations of selected pesticides and pesticide degradation products determined by the U.S. Geological Survey National Water-Quality Laboratory, Lakewood, Colorado, using laboratory schedule 2001 for water samples collected from 10 rivers in lowa, 2004. - Continued

[E, estimated; EPTC, s-ethyl dipropylthiocarbamate; <, less than; --, not detected]

\begin{tabular}{|c|c|c|c|c|c|c|c|c|c|}
\hline \multirow{2}{*}{$\begin{array}{c}\text { Map } \\
\text { number } \\
\text { (fig. 4) }\end{array}$} & \multirow{2}{*}{$\begin{array}{l}\text { U.S. Geo- } \\
\text { logical } \\
\text { Survey site } \\
\text { identifica- } \\
\text { tion number }\end{array}$} & \multirow[b]{2}{*}{ Site name } & \multirow{2}{*}{$\begin{array}{c}\text { Date of } \\
\text { collec- } \\
\text { tion } \\
\text { (month/ } \\
\text { day/ } \\
\text { year) }\end{array}$} & \multirow{2}{*}{$\begin{array}{c}\text { Collec- } \\
\text { tion } \\
\text { time } \\
\text { (24-hour) }\end{array}$} & \multicolumn{5}{|c|}{ Concentrations, in micrograms per liter } \\
\hline & & & & & $\begin{array}{l}\text { Pro- } \\
\text { panil }\end{array}$ & $\begin{array}{l}\text { Sima- } \\
\text { zine }\end{array}$ & $\begin{array}{c}\text { Tebuth- } \\
\text { iuron }\end{array}$ & $\begin{array}{c}\text { Ter- } \\
\text { bacil }\end{array}$ & $\begin{array}{l}\text { Tri- } \\
\text { flur- } \\
\text { alin }\end{array}$ \\
\hline \multirow[t]{4}{*}{3} & 05422000 & Wapsipinicon River near DeWitt & $08 / 17 / 04$ & 0745 & $<0.011$ & 0.008 & $<0.02$ & $<0.034$ & $<0.009$ \\
\hline & & & $10 / 18 / 04$ & 1520 & $<.011$ & $<.005$ & $<.02$ & $<.034$ & $<.009$ \\
\hline & & & $11 / 17 / 04$ & 0845 & $<.011$ & $<.005$ & $<.02$ & $<.034$ & $<.009$ \\
\hline & & & $12 / 06 / 04$ & 1615 & $<.011$ & $<.005$ & $<.02$ & $<.034$ & $<.009$ \\
\hline \multirow[t]{8}{*}{4} & 05474000 & Skunk River at Augusta & 03/17/04 & 1430 & $<.011$ & $<.005$ & $<.02$ & $<.034$ & $<.009$ \\
\hline & & & $06 / 16 / 04$ & 0900 & $<.011$ & .018 & $<.02$ & $<.034$ & E.005 \\
\hline & & & $07 / 20 / 04$ & 0800 & $<.011$ & $<.010$ & $<.02$ & $<.034$ & $<.009$ \\
\hline & & & 08/16/04 & 1615 & $<.011$ & $<.005$ & $<.02$ & $<.034$ & $<.009$ \\
\hline & & & 09/13/04 & 1530 & $<.011$ & .010 & $<.02$ & $<.034$ & $<.009$ \\
\hline & & & $10 / 19 / 04$ & 0845 & $<.011$ & E.004 & $<.02$ & $<.034$ & $<.009$ \\
\hline & & & $11 / 17 / 04$ & 1130 & $<.011$ & $<.005$ & $<.02$ & $<.034$ & $<.009$ \\
\hline & & & $12 / 08 / 04$ & 1150 & $<.011$ & $<.005$ & $<.02$ & $<.034$ & $<.009$ \\
\hline \multirow{5}{*}{5} & & & 08/16/04 & 1330 & $<.011$ & .009 & $<.02$ & $<.034$ & $<.009$ \\
\hline & & & $09 / 13 / 04$ & 1330 & $<.011$ & .012 & $<.02$ & $<.034$ & $<.009$ \\
\hline & & & $10 / 19 / 04$ & 1100 & $<.011$ & $<.005$ & $<.02$ & $<.034$ & $<.009$ \\
\hline & & & $11 / 17 / 04$ & 1400 & $<.011$ & $<.005$ & $<.02$ & $<.034$ & $<.009$ \\
\hline & & & $12 / 08 / 04$ & 0900 & $<.011$ & $<.005$ & $<.02$ & $<.034$ & $<.009$ \\
\hline \multirow[t]{5}{*}{6} & 06485500 & Big Sioux River at Akron & $03 / 09 / 04$ & 1200 & $<.011$ & $<.005$ & $<.02$ & $<.034$ & $<.009$ \\
\hline & & & $04 / 13 / 04$ & 0930 & $<.011$ & $<.005$ & $<.02$ & $<.034$ & $<.009$ \\
\hline & & & $05 / 12 / 04$ & 1030 & $<.011$ & $<.005$ & $<.02$ & $<.034$ & $<.009$ \\
\hline & & & $05 / 26 / 04$ & 1300 & $<.011$ & .007 & $<.02$ & $<.034$ & E.009 \\
\hline & & & $06 / 02 / 04$ & 1215 & $<.011$ & .010 & $<.02$ & $<.034$ & E.007 \\
\hline
\end{tabular}


Table 10. Concentrations of selected pesticides and pesticide degradation products determined by the U.S. Geological Survey National Water-Quality Laboratory, Lakewood, Colorado, using laboratory schedule 2001 for water samples collected from 10 rivers in lowa, 2004. - Continued

[E, estimated; EPTC, s-ethyl dipropylthiocarbamate; <, less than; --, not detected]

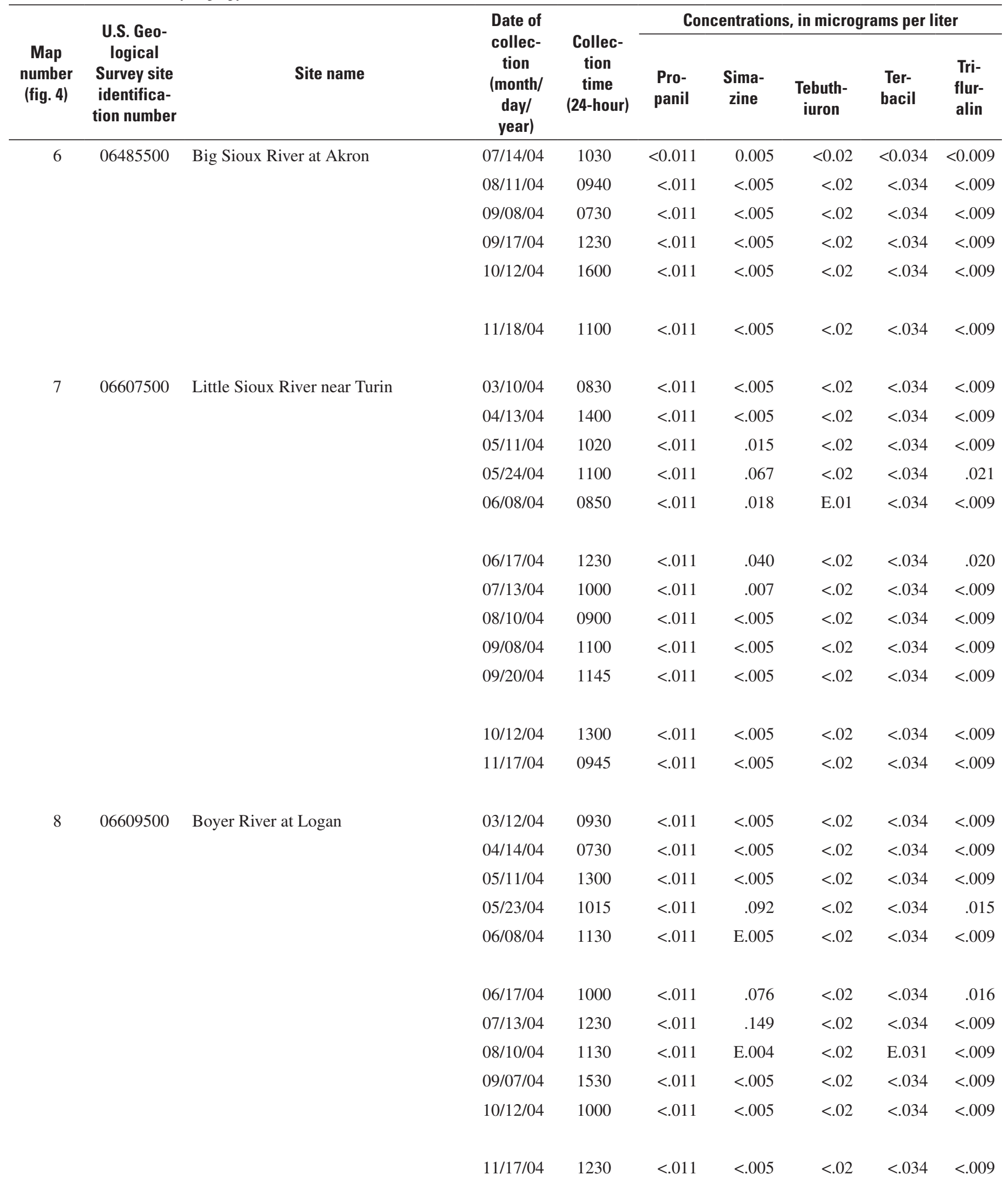


Table 10. Concentrations of selected pesticides and pesticide degradation products determined by the U.S. Geological Survey National Water-Quality Laboratory, Lakewood, Colorado, using laboratory schedule 2001 for water samples collected from 10 rivers in lowa, 2004. - Continued

[E, estimated; EPTC, s-ethyl dipropylthiocarbamate; <, less than; --, not detected]

\begin{tabular}{|c|c|c|c|c|c|c|c|c|c|}
\hline \multirow{2}{*}{$\begin{array}{c}\text { Map } \\
\text { number } \\
\text { (fig. 4) }\end{array}$} & \multirow{2}{*}{$\begin{array}{l}\text { U.S. Geo- } \\
\text { logical } \\
\text { Survey site } \\
\text { identifica- } \\
\text { tion number }\end{array}$} & \multirow[b]{2}{*}{ Site name } & \multirow{2}{*}{$\begin{array}{c}\text { Date of } \\
\text { collec- } \\
\text { tion } \\
\text { (month/ } \\
\text { day/ } \\
\text { year) }\end{array}$} & \multirow{2}{*}{$\begin{array}{c}\text { Collec- } \\
\text { tion } \\
\text { time } \\
\text { (24-hour) }\end{array}$} & \multicolumn{5}{|c|}{ Concentrations, in micrograms per liter } \\
\hline & & & & & $\begin{array}{l}\text { Pro- } \\
\text { panil }\end{array}$ & $\begin{array}{l}\text { Sima- } \\
\text { zine }\end{array}$ & $\begin{array}{l}\text { Tebuth- } \\
\text { iuron }\end{array}$ & $\begin{array}{c}\text { Ter- } \\
\text { bacil }\end{array}$ & $\begin{array}{l}\text { Tri- } \\
\text { flur- } \\
\text { alin }\end{array}$ \\
\hline \multirow[t]{7}{*}{9} & 06810000 & Nishnabotna River above Hamburg & $03 / 11 / 04$ & 1030 & $<0.011$ & $<0.005$ & $<0.02$ & $<0.034$ & $<0.009$ \\
\hline & & & $04 / 12 / 04$ & 1300 & $<.011$ & $<.005$ & $<.02$ & $<.034$ & $<.009$ \\
\hline & & & 05/10/04 & 1230 & $<.011$ & .098 & $<.02$ & $<.034$ & .035 \\
\hline & & & $05 / 25 / 04$ & 1045 & $<.011$ & .042 & $<.02$ & $<.034$ & .034 \\
\hline & & & 09/07/04 & 1230 & $<.011$ & .011 & $<.02$ & $<.034$ & $<.009$ \\
\hline & & & $10 / 13 / 04$ & 0800 & $<.011$ & $<.005$ & $<.02$ & $<.034$ & $<.009$ \\
\hline & & & $11 / 16 / 04$ & 1300 & $<.011$ & $<.005$ & $<.02$ & $<.034$ & $<.009$ \\
\hline \multirow[t]{3}{*}{10} & 06904010 & Chariton River near Moulton & $03 / 18 / 04$ & 0900 & $<.011$ & .043 & $<.02$ & $<.034$ & $<.009$ \\
\hline & & & $04 / 22 / 04$ & 1320 & $<.011$ & .031 & $<.02$ & $<.034$ & $<.009$ \\
\hline & & & $05 / 17 / 04$ & 1100 & $<.011$ & .037 & E.01 & $<.034$ & $<.009$ \\
\hline
\end{tabular}


Prepared by Lawrence Publishing Service Center. Edited by Lanna Combs.

Graphics by Jeff Hartley and Mike Kemppainen. Layout and design by Kristi Hartley.

For more information concerning the research described in this report, contact:

U.S. Geological Survey

4821 Quail Crest

Lawrence, KS 66049-3839

(785) 842-9909

http://ks.water.usgs.gov 


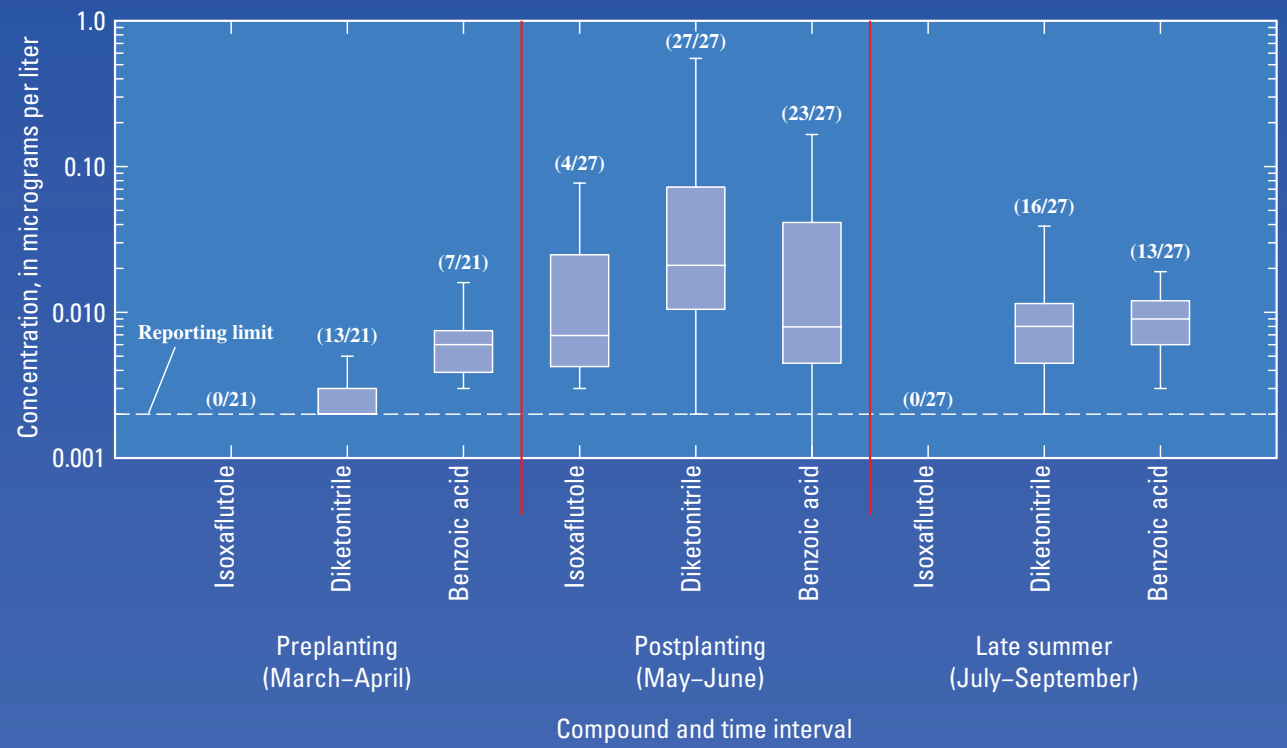

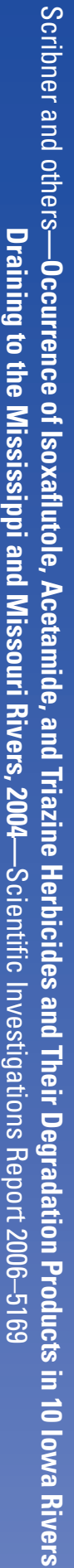

